\title{
Particulate Measurements and Emissions Characterization of Alternative Fuel Vehicle Exhaust
}

T.D. Durbin, T.J. Truex, and J.M. Norbeck

Center for Environmental Research and Technology College of Engineering, University of California Riverside, California

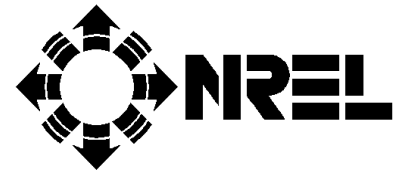

National Renewable Energy Laboratory 1617 Cole Boulevard

Golden, Colorado 80401-3393

A national laboratory of the U.S. Department of Energy Managed by Midwest Research Institute for the U.S. Department of Energy under contract No. DE-AC36-83CH10093 


\section{Particulate Measurements and Emissions Characterization of Alternative Fuel Vehicle Exhaust}

T.D. Durbin, T.J. Truex, and J.M. Norbeck

Center for Environmental Research and Technology College of Engineering, University of California Riverside, California

NREL technical monitor: P. Bergeron

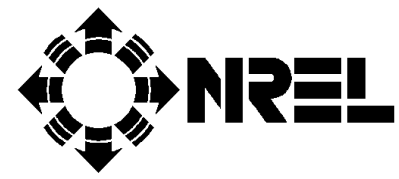

National Renewable Energy Laboratory 1617 Cole Boulevard Golden, Colorado 80401-3393 A national laboratory of the U.S. Department of Energy Managed by Midwest Research Institute for the U.S. Department of Energy under contract No. DE-AC36-83CH10093

Prepared under Subcontract No. ACI-7-16637-01

November 1998 


\section{NOTICE}

This report was prepared as an account of work sponsored by an agency of the United States government. Neither the United States government nor any agency thereof, nor any of their employees, makes any warranty, express or implied, or assumes any legal liability or responsibility for the accuracy, completeness, or usefulness of any information, apparatus, product, or process disclosed, or represents that its use would not infringe privately owned rights. Reference herein to any specific commercial product, process, or service by trade name, trademark, manufacturer, or otherwise does not necessarily constitute or imply its endorsement, recommendation, or favoring by the United States government or any agency thereof. The views and opinions of authors expressed herein do not necessarily state or reflect those of the United States government or any agency thereof.

Available to DOE and DOE contractors from:

Office of Scientific and Technical Information (OSTI)

P.O. Box 62

Oak Ridge, TN 37831

Prices available by calling 423-576-8401

Available to the public from:

National Technical Information Service (NTIS)

U.S. Department of Commerce

5285 Port Royal Road

Springfield, VA 22161

703-605-6000 or 800-553-6847

or

DOE Information Bridge

http://www.doe.gov/bridge/home.html 


\section{Contents}

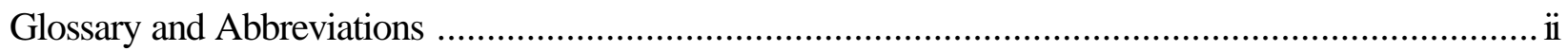

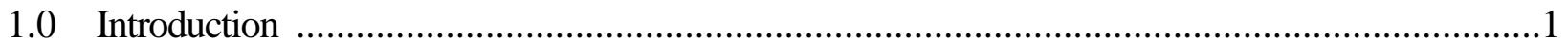

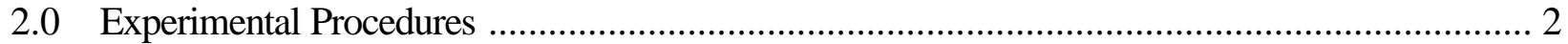

2.1 Vehicle Fleet Description and Recruitment ...................................................... 2

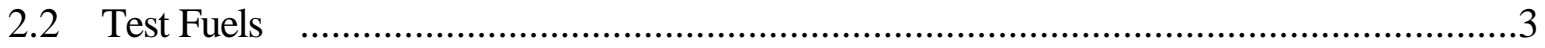

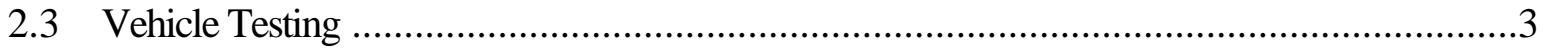

2.4 Particulate Sample Collection ........................................................................... 3

2.5 Particulate Sample Analysis ......................................................................... 5

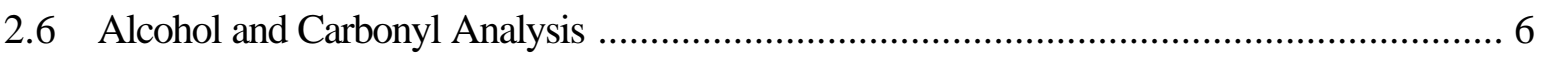

3.0 Emissions Test Results and Discussion ....................................................................... 7

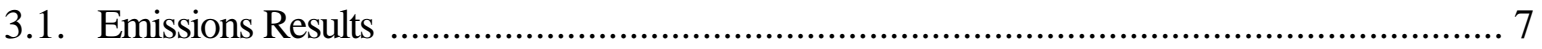

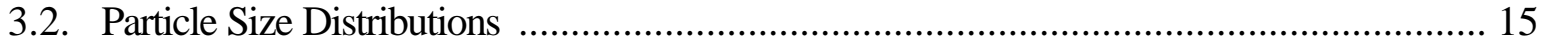

4.0 Chemical Analysis Results and Discussion ............................................................... 19

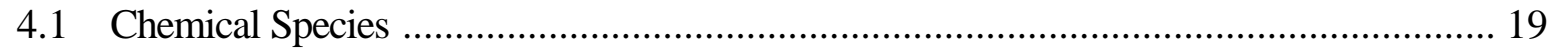

4.2 PAH, Hopane, and Sterane Emission Results ................................................... 28

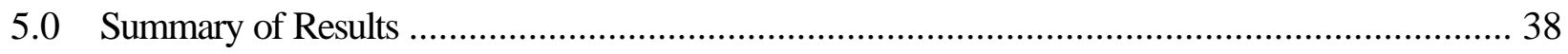

6.0 Conclusions and Recommendations .......................................................................... 40

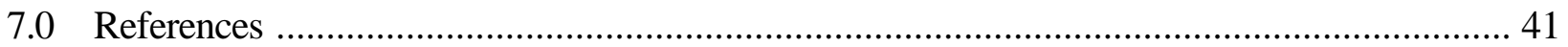




\section{List of Figures}

Figure 1. FTP Weighted Average Emission Results for CNG and RFG Dodge Caravans ..................9

Figure 2. US06 Average Emission Results for CNG and RFG Dodge Caravans ............................10

Figure 3. FTP Weighted Average Emission Results for M85 and RFG FFV Ford Tauruses ..............13

Figure 4. US06 Average Emission Results for M85 and RFG FFV Ford Tauruses .........................16

Figure 5. Average Particulate Size Distributions for FTP........................................................... 17

Figure 6. Average Particulate Size Distributions for US06 …................................................. 18

Figure 7. PM Chemical Mass Emission Rates for CNG/RFG Dodge Caravans for FTP..................24

Figure 8. PM Chemical Mass Emission Rates for M85/RFG Ford Tauruses for FTP .....................25

Figure 9. PM Chemical Mass Emission Rates for CNG/RFG Dodge Caravans for US06 ................26

Figure 10. PM Chemical Mass Emission Rates for M85/RFG Ford Tauruses for US06..................27

Figure 11. PAH Mass Emission Rates for CNG/RFG Dodge Caravans for FTP .............................30

Figure 12. PAH Mass Emission Rates for M85/RFG Ford Tauruses for FTP ...............................31

Figure 13. PAH Mass Emission Rates for CNG/RFG Dodge Caravans for US06 ..........................32

Figure 14. PAH Mass Emission Rates for M85/RFG Ford Tauruses for US06.............................33 


\section{List of Tables}

Table 1. AFV Testing Matrix................................................................................................2

Table 2. FTP Weighted Average Emission Results for CNG and RFG Dodge Caravans ....................8

Table 3. US06 Average Emission Results for Dodge Caravans on CNG and RFG ........................11

Table 4. FTP Average Emission Results for FFV Ford Tauruses on M85 and RFG.......................12

Table 5. FTP Methanol and Formaldehyde Results for Ford Tauruses on M85 and RFG................14

Table 6. US06 Average Emission Results for FFV Ford Tauruses on M85 and RFG......................15

Table 7. Statistics for CNG and RFG Dodge Caravans for FTP PM Chemical Species Emission

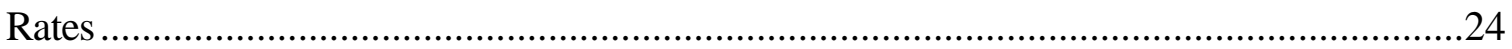

Table 8. Statistics for M85 and RFG Ford Tauruses for FTP PM Chemical Species Emission Rates.....

Table 9. Statistics for CNG and RFG Dodge Caravans for US06 PM Chemical Species Emission

Rates

Table 10. Statistics for M85 and RFG Ford Tauruses for US06 PM Chemical Species Emission

Rates .

Table 11. Statistics for CNG and RFG Dodge Caravans for FTP PAH Emissions 34

Table 12. Statistics for M85 and RFG FFV Ford Tauruses for FTP PAH Emissions 35

Table 13. Statistics for CNG and RFG Dodge Caravans for US06 PAH Emissions 36

Table 14. Statistics for M85 and RFG FFV

Ford Tauruses for US06 PAH Emissions 


\section{List of Appendices}

Appendix A. Fuel Properties for RFG, M85 Blend (w/RFG) and CNG ..................................... A-1

Appendix B. Particle and Gas-Phase Emissions Summary for FTP and US06 ...................................

Appendix C. Emissions Summary of Alcohols, Aldehydes, and Ketones for

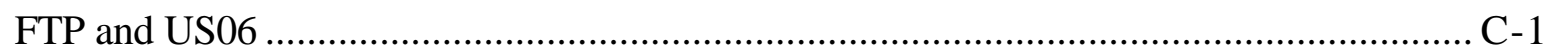

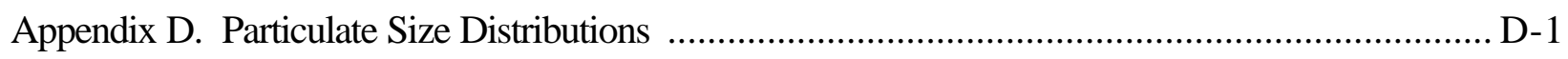

Appendix E. Comparison of PTFE Filter and MOUDI Mass Emission Rates...................................E-1

Appendix F. Chemical Mass Emission Rates for FTP Tests........................................................

Appendix G. Chemical Mass Emission Rates for US06 Tests........................................................ G-1 


\section{Abstract}

The objective of this project was to measure and characterize particulate emissions from light-duty alternative fuel vehicles (AFVs) and equivalent gasoline-fueled vehicles. This work is part of a more extensive research program co-sponsored by the Coordinating Research Council, the South Coast Air Quality Management District, and the National Renewable Energy Laboratory (NREL) to augment the current database of particulate emissions from conventional vehicles and light-duty AFVs. It includes particulate emission testing of a fleet of 129 gasoline-fueled vehicles and 19 diesel vehicles (Norbeck, Durbin, and Truex 1998). Particulate measurements were obtained over Federal Test Procedure (FTP) and US06 cycles for total particulate, as well as the fraction of particulate below 1.0, 2.5, and $10.0 \mu \mathrm{m}$. Chemical characterization of the exhaust particulate was also performed, including determination of organic and elemental carbon fractions, analysis for trace elements and ions, and speciation of polynuclear aromatic hydrocarbons (PAHs), hopanes, and steranes.

FTP average particulate emissions for compressed natural gas (CNG) and $85 \%$ methanol/15\% gasoline (M85) fueled vehicles were 1.40 and $0.70 \mathrm{mg} / \mathrm{mi}$, respectively. These values are low and comparable to those of their gasoline counterparts. $\mathrm{CNG}$ vehicles produced lower non-methane hydrocarbon (NMHC) and carbon monoxide (CO) emissions than gasoline vehicles for both the FTP and the US06. Oxides of nitrogen $\left(\mathrm{NO}_{\mathrm{x}}\right)$ emissions for $\mathrm{CNG}$ vehicles were comparable to those for the gasoline vehicles for the fleet average, and slightly lower when the highest-emitting CNG vehicle was removed from the average. M85 produced lower $\mathrm{NO}_{\mathrm{x}}$ emissions but higher $\mathrm{CO}$ and organic material hydrocarbon equivalent (OMHCE) emissions than did reformulated gasoline (RFG) over the FTP. M85 produced lower emissions than RFG for total hydrocarbons (THC), $\mathrm{NMHC}, \mathrm{CO}$, and $\mathrm{NO}_{\mathrm{x}}$ over the US06 cycle. Particulate, $\mathrm{NO}_{\mathrm{x}}$ and $\mathrm{CO}$ emissions were higher from the more aggressive US06 cycle than from the FTP for all vehicle/fuel combinations, with some vehicles having significant increases in particulate emissions over the US06. Average US06 particulate emissions were 7.76 and $3.62 \mathrm{mg} / \mathrm{mi}$, respectively, for the CNG and M85 vehicles, or a factor of more than 5 greater than the FTP values. Most of the particulate mass was below $10 \mu \mathrm{m}$ in aerodynamic diameter (77\%-92\%) with 58\%-82\% of the mass below $2.5 \mu \mathrm{m}$, and $42 \%-77 \%$ below $1.0 \mu \mathrm{m}$.

Particulate samples were analyzed for organic and elemental carbon, trace elements and ions. Elemental and organic carbon were primary constituents. Other species identified include possible fuel-derived components $\left(\mathrm{SO}_{4}{ }^{2-}, \mathrm{S}\right)$ and oil/wear derived components $(\mathrm{Mg}, \mathrm{P}, \mathrm{Ca}, \mathrm{Zn}, \mathrm{Fe}, \mathrm{Si}$, and $\mathrm{Al})$. Low emissions levels and large sample-to-sample variability made it difficult to differentiate between the species profiles for different vehicle/fuel combinations. PAH emissions were highest for the RFG vehicles over the FTP and the US06. PAH emissions for M85 vehicles were considerably lower than RFG over the US06; PAH emissions for CNG vehicles were considerably lower than those for RFG vehicles over both the FTP and US06. 


\section{Glossary and Abbreviations}

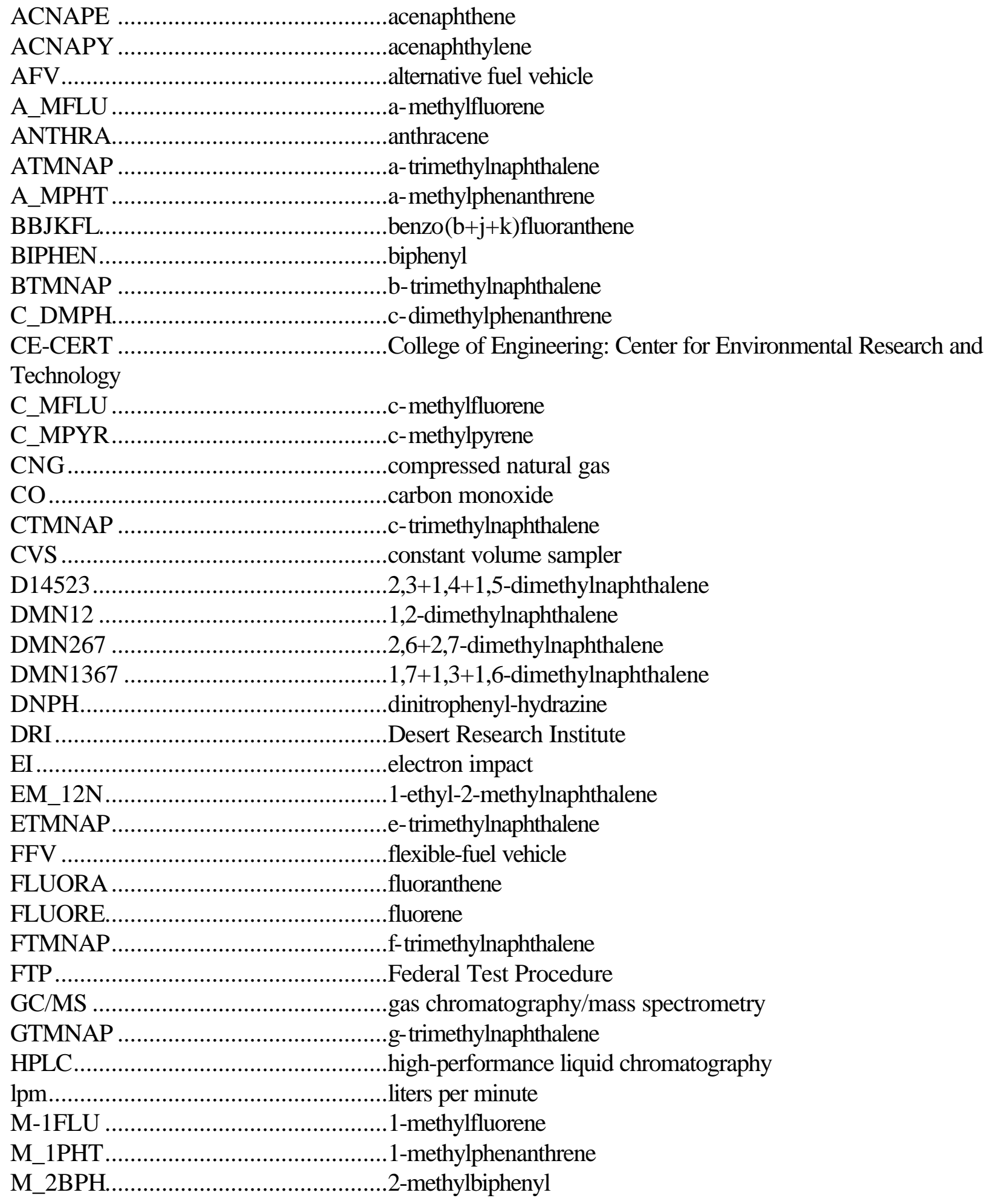




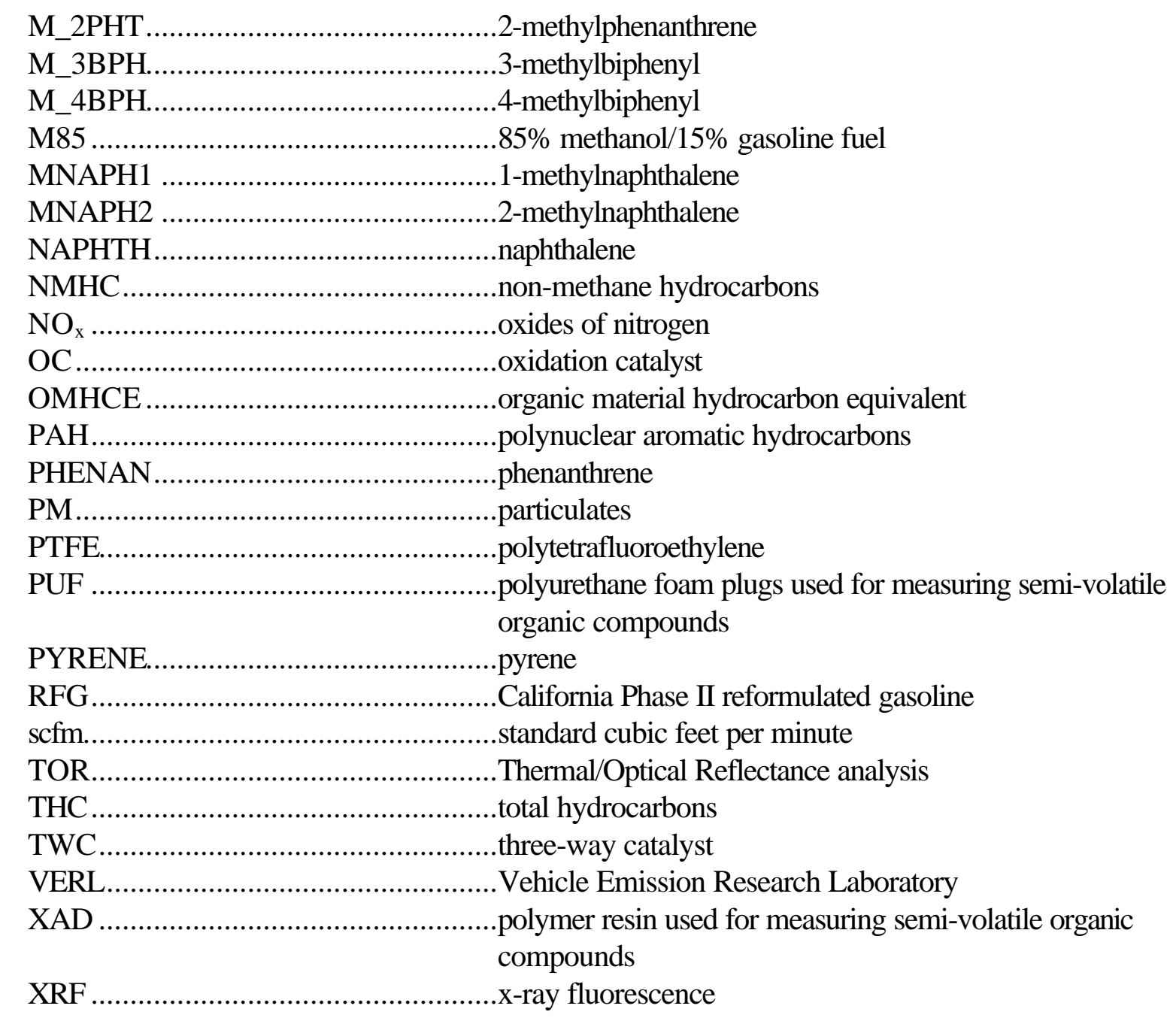




\subsection{Introduction}

Although significant improvements in air quality have been made over the past 20 years, many parts of the country still do not comply with National Ambient Air Quality Standards (NAAQS). To help address this problem, Congress enacted the Clean Air Act Amendments of 1990, with provisions to force broad changes in fuels and vehicles. As the transportation industry struggles to comply with these regulations, alternative fuels and reformulated gasolines have emerged as important components of many air pollution reduction plans. Alternative fuels, in particular, offer the potential dual benefits of energy independence and an improvement in air quality. For alternative fuels to be viable replacements for their petroleum-based counterparts, however, their impact on air quality must be assessed. Although much research has shown potential air quality benefits from alternative transportation fuels, many uncertainties still exist in the technical community about the impacts of alternative fuels, and the emissions rates and composition of some combustion products.

One pollutant that has received considerable attention recently is particulate matter. Recent studies indicate that increases in human mortality and morbidity are associated with particulate (PM) pollution levels significantly lower than those previously believed to affect human health (Dockery and Pope, 1994; Health Effects Institute, 1995). Limited studies have shown that particulate emission rates from properly functioning modern gasoline-fueled vehicles are small: on the order of 2-10 mg/mi (Hammerle et al.,1991; Siegel et al.; 1994; Zinbo, Karniski, and Weir, 1995). Several recent studies have shown, however, that high carbon monoxide (CO) emitting and smoking vehicles can have particulate emission rates several orders of magnitude higher than properly functioning modern gasoline-fueled vehicles (Dickson, Henning, and Oliver, 1991; Sagebiel et al., 1997; Cadle et al., 1997; Durbin et al., 1999).

The objective of this project was to measure particulate emissions from light-duty alternative fuel vehicles (AFVs) and equivalent gasoline-fueled vehicles. Particulate measurements were obtained over Federal Test Procedure (FTP) and US06 cycles. Measurements included total particulate as well as the fraction of particulates below 1.0, 2.5, and $10.0 \mu \mathrm{m}$. Chemical characterization of the exhaust particulate was also performed, including determination of organic and elemental carbon fractions, analysis for trace elements and ions, and speciation of polynuclear aromatic hydrocarbons (PAHs), hopanes, and steranes. This work is part of a more extensive research program co-sponsored by the Coordinating Research Council, the South Coast Air Quality Management District, and the National Renewable Energy Laboratory to augment the current database of particulate emissions from conventional and alternative fuel light-duty vehicles, and includes particulate emission testing of a fleet of 129 gasoline-fueled vehicles and 19 diesel vehicles (Norbeck, Durbin, and Truex, 1998). 


\subsection{Experimental Procedures}

\subsection{Vehicle Fleet Description and Recruitment}

Table 1 lists and describes the vehicles tested in this program. For each fuel category, five vehicles with the same make, model, and model year were selected for testing. In conjunction with each AFV tested, control tests also were performed. Control tests were run on California Phase II Reformulated Gasoline (RFG) using the same engine or vehicle for M85, and on vehicles with the same make, model, and model year for the CNG vehicles. To the extent possible, CNG and RFG control vehicles with similar mileages were sought. Although there were some differences in the mileages for the CNG and RFG control vehicles, the effect of mileage on the emissions results is expected to be small in comparison with the effects observed for vehicles operating on different fuel types. Where possible all vehicles within a specific fuel group were obtained from the same fleet operator. The CNG Dodge Caravans were obtained from the University of California, Riverside, fleet services department. The RFG Dodge Caravans were all obtained from VPSI Inc., a commuter van service. The Ford flexible-fuel Tauruses were all obtained from private owners.

Table 1. AFV Testing Matrix

\begin{tabular}{|c|c|c|c|c|c|c|}
\hline & $\begin{array}{c}\text { Model } \\
\text { Year }\end{array}$ & Make & Model & $\begin{array}{c}\text { Odometer } \\
\text { (miles) }\end{array}$ & Engine Size/Type & Catalyst Type \\
\hline \multicolumn{7}{|c|}{ CNG Vehicles } \\
\hline 1 & 1994 & Dodge & Caravan & 30,793 & 3.3L V6 & TWC+OC \\
\hline 2 & 1994 & Dodge & Caravan & 38,154 & $3.3 \mathrm{~L} \mathrm{V6}$ & $\mathrm{TWC}+\mathrm{OC}$ \\
\hline 3 & 1994 & Dodge & Caravan & 21,321 & 3.3L V6 & $\mathrm{TWC}+\mathrm{OC}$ \\
\hline 4 & 1994 & Dodge & Caravan & 14,117 & 3.3L V6 & $\mathrm{TWC}+\mathrm{OC}$ \\
\hline 5 & 1994 & Dodge & Caravan & 46,765 & $3.3 \mathrm{~L} \mathrm{V6}$ & $\mathrm{TWC}+\mathrm{OC}$ \\
\hline \multicolumn{7}{|c|}{ RFG Control Vehicles } \\
\hline 1 & 1994 & Dodge & Caravan & 40,834 & 3.3L V6 & TWC \\
\hline 2 & 1994 & Dodge & Caravan & 48,478 & 3.3L V6 & TWC \\
\hline 3 & 1994 & Dodge & Caravan & 65,335 & 3.3L V6 & TWC \\
\hline 4 & 1994 & Dodge & Caravan & 73,354 & 3.3L V6 & TWC \\
\hline 5 & 1994 & Dodge & Caravan & 74,379 & 3.3L V6 & TWC \\
\hline \multicolumn{7}{|c|}{ M85 and RFG Control Vehicles (operated on M85 and RFG) } \\
\hline 1 & 1994 & Ford & FFV Taurus & 98,328 & 3.0L V6 & TWC \\
\hline 2 & 1994 & Ford & FFV Taurus & 31,660 & 3.0L V6 & TWC \\
\hline 3 & 1994 & Ford & FFV Taurus & 47,973 & 3.0L V6 & TWC \\
\hline 4 & 1994 & Ford & FFV Taurus & 61,499 & $3.0 \mathrm{~L} \mathrm{V6}$ & TWC \\
\hline 5 & 1994 & Ford & FFV Taurus & 51,988 & 3.0L V6 & TWC \\
\hline
\end{tabular}

\subsection{Test Fuels}

The three test fuels used for this project were CNG, M85, and RFG. M85 and RFG were both obtained from Phillips Petroleum Company in Borger, Texas. The M85 for testing was produced by splash-blending $85 \%$ pure methanol with $15 \%$ RFG. The fuel for the CNG vehicles was obtained from 
the local campus supply station, which was common to all the CNG test vehicles. Appendix A presents fuel specifications and analyses on fuel samples for the CNG, M85, and RFG.

\subsection{Vehicle Testing}

Each vehicle/fuel combination was tested for total hydrocarbons (THC), non-methane hydrocarbons (NMHC), $\mathrm{CO}$, oxides of nitrogen ( $\mathrm{NO}_{\mathrm{x}}$ ), and particulate emissions over back-to-back FTPs on consecutive days. Immediately following the completion of the second FTP for each vehicle/fuel combination, each vehicle was tested over 2-4 iterations of the US06 cycle for gaseous and particulate emissions. Four iterations of the US06 were used to collect sufficient particulate samples for chemical analysis. Alcohol and carbonyl emissions were also collected on a subset of the tests on the M85 and RFG vehicles. The details of the particulate and alcohol sampling are presented in Sections 2.4 and 2.6, respectively. All M85 and RFG vehicles were refueled and preconditioned using the procedures developed through Auto/Oil program (Burns et al., 1991). The heat build steps were excluded from the preconditioning because evaporative emissions tests were not conducted. The CNG Dodge Caravans were preconditioned over one iteration of the LA4 driving schedule. All vehicles were soaked overnight between $72 \pm 2^{\circ} \mathrm{F}$ after preconditioning and prior to testing.

All tests were conducted in CE-CERT's Vehicle Emission Research Laboratory (VERL) equipped with a Burke E. Porter 48-inch single-roll electric dynamometer and a Pierburg constant volume sampler (CVS)/dilution tunnel system. Sampling was conducted with VERL's 10-inch-diameter dilution tunnel. CVS flow rates of 350 and 493 standard cubic feet per minute ( $\mathrm{scfm}$ ), respectively, were used for FTP and US06 testing for gasoline vehicles. CVS flow rates of 693 and $856 \mathrm{scfm}$ were used for FTP and US06 testing for M85 and CNG-fueled vehicles. Higher flow rates were used for the US06 cycle to provide greater exhaust dilution due to larger exhaust volumes expected for the more aggressive driving schedule. Some tunnel temperatures in excess of $52^{\circ} \mathrm{C}$ were still recorded, however, during the most aggressive portions of the US06 cycle. Higher flow rates were used for CNG and M85 vehicles because combustion of these fuels produce higher concentrations of water in the exhaust.

\subsection{Particulate Sample Collection}

The particulate sampling protocol for this project was designed to provide mass emissions rates, size distributions, and samples for analysis for organic and elemental carbon fractions, metals and inorganic ions, and speciation of the organic fraction of the particulate. The particulate sampling and analysis plan for this project follows:

- For each of the 20 vehicle/fuel combinations, FTP particulate mass emission rates were determined, as well as the fraction of mass below $1.0,2.5$, and $10.0 \mu \mathrm{m}$ in aerodynamic diameter.

- For each of the 20 vehicle/fuel combinations, particulate samples were collected for analysis of organic and inorganic carbon, and determination of trace elements and ions. FTP samples were analyzed for all five vehicles within each fuel/vehicle group (i.e., CNG Dodge Caravan, RFG Dodge Caravan, M85 Ford Taurus, and RFG Ford Taurus); US06 samples were analyzed for two vehicles within each fuel/vehicle group. 
- For each of the four vehicle/fuel groups, samples were collected for detailed speciation of the PAHs, hopanes, and steranes. The samples for each fuel/vehicle group were "pooled" by combining individual samples from within each group. Samples for the FTP for each fuel/vehicle group were "pooled" using samples from all five vehicles. Samples for the US06 for each fuel/vehicle group were "pooled" using samples from only two vehicles.

The dilution tunnel used for sampling was fitted with three sampling probes located about 100 inches downstream of the exhaust mixing flange. The sampling configuration, filter media, and analyses are summarized below.

- Probe 1 was fitted with $47 \mathrm{~mm}, 2.0 \mu \mathrm{m}$ Gelman Teflon membrane filters using a Pierburg particle sampling system to obtain total mass particulate emission rates for each phase of the FTP. This probe holds three filter assemblies with automatic sampling for each phase of the FTP. Each filter assembly was fitted with a primary and a backup filter.

- Probe 2 was fitted with a two-way flow splitter. One filter holder was fitted with prefired Pallflex 2500 QAT-UP quartz fiber filters for organic and elemental carbon analyses, and detailed speciation of the particulate PAHs, hopanes, and steranes. Thin stainless-steel rings were placed in front of the quartz fiber filters to provide a more uniform and well-defined deposit for carbon analysis. The quartz filters were backed up using a vapor-phase trap for PAHs consisting of XAD-4 resin (polystyrene divinylbenzene polymer) sandwiched between two polyurethane foam (PUF) plugs for collection of semi-volatile PAHs. The other filter holder was fitted with $47 \mathrm{~mm}$ Gelman Teflon membrane filters for analyses of trace elements, and determination of sulfate, nitrate, ammonium, and chloride ions.

- $\quad$ Probe 3 was fitted with a MOUDI cascade impactor for collection of size segregated samples. Uncoated aluminum foils were used for impaction substrates together with $47 \mathrm{~mm}, 2.0 \mu \mathrm{m}$ pore size Gelman Teflon membrane after-filters. For each test, the MOUDI was configured using the stages corresponding to cut-points of $>18,10,3.2,1.8$, and $1.0 \mu \mathrm{m}$ aerodynamic diameter and fitted with an after-filter to determine the total mass below 10.0, 2.5, and $1.0 \mu \mathrm{m}$ aerodynamic diameter.

Although there is no specific impaction substrate for the collection of $2.5 \mu \mathrm{m}$ particulate, the mass of particulate below $2.5 \mu \mathrm{m}$ can be obtained by assuming that half of the mass collected on the $1.8 \mu \mathrm{m}$ impaction substrate is from sub- $2.5 \mu \mathrm{m}$ particles.

For each test, mass emission rates were determined for each bag of the FTP, using two iterations of the FTP. Samples for chemical analysis on quartz-fiber filters and the PUF/XAD substrate, and Teflon membrane filters were collected cumulatively over both back-to-back FTPs. MOUDI samples were also collected cumulatively over both back-to-back FTPs. Each FTP sequence was performed twice to obtain sufficient sample for mass analysis by bag and chemical analysis. All samples were collected cumulatively over the two to four US06 cycles. Four iterations of the US06 cycle were performed on two vehicles within each fuel/vehicle group to obtain samples for analysis of elemental and organic carbon, trace elements, and ions and "pooled" samples for PAH, hopane, and sterane analyses. Only two iterations were performed on the remaining three vehicles in each fuel/vehicle group to obtain samples for mass analysis. 
For the CNG Dodge Caravans and the Ford Tauruses operated on M85, sampling rates for total particulate mass by bag of the FTP (Probe 1) were collected at $80 \mathrm{lpm}$. Polytetrafluoroethyelene (PTFE) and quartz fiber filters for chemical analyses were sampled at $60 \mathrm{lpm}$. For the conventional RFG vehicles, sampling rates for total particulate mass by bag of the FTP (Probe 1) were collected at $47 \mathrm{lpm}$. PTFE and quartz fiber filters for chemical analyses were sampled at 30 and $60 \mathrm{lpm}$, respectively. MOUDI samples for all tests were collected at $30 \mathrm{lpm}$. It should be noted that higher sampling rates were used for the AFVs to compensate for the increased dilution for these vehicles. All particulate sampling was performed under isokinetic sampling conditions using removable probe tips of different diameters.

\subsection{Particulate Sample Analysis}

Teflon membrane and aluminum MOUDI substrates were weighed before and after sampling to determine the collected mass using an ATI Orion ultra-microbalance. The microbalance is located in an environmental weighing chamber maintained at a temperature of $25^{\circ} \pm 0.5^{\circ} \mathrm{C}$ and a relative humidity of $40 \pm 5 \%$. Before and at the completion of sample collection, substrates were preconditioned for at least 24 hours in the environmental chamber before weighing. Particulate mass emission rates were corrected based on the daily tunnel blank measurements, which averaged $0.07 \pm 0.11 \mathrm{mg} / \mathrm{mi}$ with a range from 0.00 to $0.49 \mathrm{mg} / \mathrm{mi}$. Tunnel blanks were collected daily over a period of time roughly corresponding to Bag 2 of the FTP. The precision for particulate mass emissions measurements is $0.13 \mathrm{mg} / \mathrm{mi}$ at one sigma for the FTP tests. Minimum detection limits are about two to three times the measurement precision.

The Teflon membrane filters collected from Probe 2 were utilized for chemical analysis of metals and other trace elements, and sulfate, nitrate, ammonium, and chloride ions. All analyses were conducted by the Desert Research Institute (DRI). Samples were stored in petri dishes in a refrigerator before shipment to DRI. Shipment to DRI was in a cooler with blue ice packs. Metals and other trace elements were analyzed using X-ray fluorescence (XRF). Filters were then extracted in a 60:40 mixture of isopropyl alcohol and distilled, deionized water for nitrate and sulfate analyses using ion chromatography. A separate extraction with distilled, deionized water was used for analysis of chloride and ammonium ions, because the isopropyl alcohol causes interference in the measurements of these two ions. Chloride ions were measured using ion chromatography; ammonium ions were measured using automated colorimetry.

The quartz fiber filters collected at Probe 2 were used for elemental and organic carbon analyses. Quartz fiber filters were obtained from DRI after prefiring at $900^{\circ} \mathrm{C}$ for three hours to reduce background carbon levels. The filters were shipped in blue ice to the College of Engineering: Center for Environmental Research and Technology (CE-CERT) and stored in a refrigerator until use. After sampling, filters were stored in a refrigerator in petri dishes lined with aluminum foil prior to return shipment to DRI in a cooler with blue ice packs. Elemental and organic carbon analyses were performed by DRI using the thermal optical reflectance method (Chow et al., 1993). Analyses were performed on a $0.512 \mathrm{~cm}^{2}$ punch from the filter.

$\mathrm{PAH} /$ hopane/sterane analyses were performed on the PUF/XAD vapor-phase trap and quartz fiber filters. PUF/XAD backup cartridges were utilized to collect semi-volatile PAH/hopanes/steranes. XAD resin and PUF cartridges were obtained precleaned from DRI. The XAD resin was cleaned by washing with distilled water, followed by Soxhlet extraction for 24 hours with methanol. The resin was then 
drained and Soxhlet extracted for an additional 24 hours with dichloromethane $\left(\mathrm{CH}_{2} \mathrm{Cl}_{2}\right)$. The resin was dried in a vacuum oven at $40^{\circ} \mathrm{C}$. PUF cartridges were cleaned by first washing with distilled water followed by Soxhlet extraction for 24 hours in acetone, followed by Soxhlet extraction for 24 hours in $10 \%$ diethyl ether in hexane. The extracted PUFs were dried in a vacuum oven connected to a water aspirator and dried at room temperature for approximately 2-4 hours. XAD resin and PUF cartridges were stored in a freezer prior to sampling and after sampling prior to return to DRI. XAD and PUF filters were shipped from DRI to CE-CERT and from CE-CERT back to DRI in a cooler with blue ice.

The PUF/XAD vapor trap was combined with the quartz fiber filter from the corresponding test for extraction. This provides a combined sample of semi-volatile and particulate phase $\mathrm{PAH} /$ hopanes/steranes. Filter samples from more than one test were combined to provide an adequate sample for analyses, as discussed in section 2.4. Filters were extracted in $\mathrm{CH}_{2} \mathrm{CL}_{2}$ for 8 hours. Prior to extraction, deuterated internal standards were added to each sample. Extracts were analyzed by electron impact (EI) gas chromatography/mass spectrometry (GC/MS) technique.

\subsection{Alcohol and Carbonyl Analysis}

Methanol and carbonyl measurements were collected on a subset of the tests performed on the RFG and M85 test vehicles. For each RFG and M85 vehicle/fuel combination, alcohol and carbonyl measurements were collected on the first of the back-to-back FTPs. Additional alcohol and carbonyl measurements were collected on one US06 test for two of five RFG Dodge Caravans, and two of the five FFV Ford Tauruses on both RFG and M85. Exhaust methanol was collected using water impingers and analyzed with a gas chromatograph/flame ionization detector. Dilute exhaust gas aldehydes and ketones collected on dinitrophenyl-hydrazine (DNPH)-coated silica gel cartridges. DNPH cartridges were analyzed by high performance liquid chromatography (HPLC). Methanol, aldehydes, and ketones were all sampled through a heated line $\left(110^{\circ} \mathrm{C}\right)$. 


\subsection{Emissions Test Results and Discussion}

The testing results for particulate and gas phase emissions are summarized in Sections 3.1 and 3.2, respectively. The complete particulate and gas-phase emissions for individual tests are presented in Appendix B. The complete methanol and carbonyl results are presented in Appendix C.

\subsection{Emissions Results}

The FTP emissions results for the CNG and RFG Dodge Caravans are presented in Table 2 and Figure 1. The particulate emission results are obtained from cumulative particulate samples; the gaseous emissions are the averages over both tests. These results show that the particulate emissions from the RFG and CNG test vehicles are both relatively low and comparable. The resulting particulate emissions are also comparable to those found for newer gasoline vehicles in the more comprehensive study of inuse gasoline vehicles (Norbeck, Durbin, and Truex, 1998). In this work, the average FTP emission rate for 1991-1997 gasoline vehicles was $2.5 \mathrm{mg} / \mathrm{mi}$ with a median of $1.2 \mathrm{mg} / \mathrm{mi}$.

For gaseous emissions, the $\mathrm{CNG}$ vehicles produced lower $\mathrm{NMHC}$ and $\mathrm{CO}$ emissions than the RFG vehicles. NMHC emissions from the CNG vehicles were $83 \%$ lower than those from the RFG vehicles. $\mathrm{CO}$ emissions were $38 \%$ lower for the CNG fleet than for the RFG vehicles. Averages were also presented excluding CNG vehicle \#1. Although no particular problems were noted with this vehicle, emissions considerably higher than expected for its ultra low emission vehicle (ULEV) certification indicate that this may not have been a representative test vehicle. Excluding CNG vehicle \#1, the average $\mathrm{CO}$ emission rate for $\mathrm{CNG}$ is reduced further to $0.527 \mathrm{~g} / \mathrm{mi}$ or an overall reduction of about $76 \%$. $\mathrm{NO}_{\mathrm{x}}$ emissions for the $\mathrm{CNG}$ vehicles were comparable to those for the RFG vehicles for the fleet average, and slightly lower than RFG when CNG vehicle \#1 was excluded.

The results for the US06 tests for CNG and RFG Dodge Caravans are presented in Table 3 and Figure 2. Overall, the emissions of $\mathrm{CO}, \mathrm{NO}_{\mathrm{x}}$, and $\mathrm{PM}$ are all higher than for the FTP, with relatively significant increases in particulate mass emission rates for some of the CNG (\#1 and \#4) and RFG (\#1, \#3, and $\# 4)$ vehicles. Increases relative to the FTP of $72 \%$ and $103 \%$ were observed for $\mathrm{CO}$ and $\mathrm{NO}_{\mathrm{x}}$, respectively, for CNG vehicles over the US06. US06 particulate emissions increased by more than a factor of 5 over the FTP, to $7.76 \mathrm{mg} / \mathrm{mi}$ for the CNG vehicles and $6.63 \mathrm{mg} / \mathrm{mi}$ for the RFG vehicles. In comparing the CNG and RFG vehicles, trends similar to those observed for the FTP were found. In particular, emissions for NMHC and $\mathrm{CO}$ were lower for the $\mathrm{CNG}$ vehicles, while emissions for the particulate were similar between the two vehicle groups. Emissions of NMHC were $93 \%$ lower for the CNG vehicles than the RFG vehicles, and CO emissions were approximately $85 \%$ lower for the CNG vehicles. Excluding $\mathrm{CNG}$ vehicle \#1 resulted in even further reductions in $\mathrm{CNG}$ vehicles, with average emission rates of $0.008 \mathrm{~g} / \mathrm{mi}$ for $\mathrm{NMHC}$ and $1.294 \mathrm{~g} / \mathrm{mi}$ for $\mathrm{CO} . \mathrm{NO}_{\mathrm{x}}$ emissions for the US06 were comparable for CNG and RFG over the fleet average, and lower for CNG with CNG vehicle \#1 excluded. 
Table 2. FTP Weighted Average Emission Results for CNG and RFG Dodge Caravans

1994 CNG Dodge Caravan Results

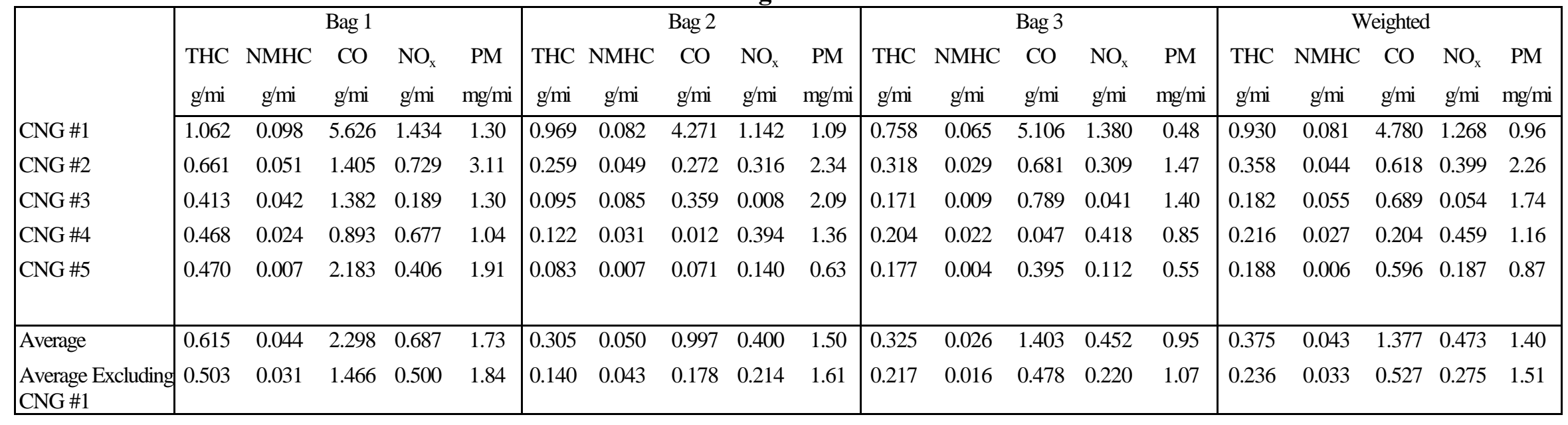

1994 RFG Dodge Caravan Results

\begin{tabular}{|c|c|c|c|c|c|c|c|c|c|c|c|c|c|c|c|c|c|c|c|c|}
\hline \multirow[b]{3}{*}{ RFG \#1 } & \multicolumn{5}{|c|}{ Bag 1} & \multicolumn{5}{|c|}{ Bag 2} & \multicolumn{5}{|c|}{ Bag 3} & \multicolumn{5}{|c|}{ Weighted } \\
\hline & $\begin{array}{l}\mathrm{THC} \\
\mathrm{g} / \mathrm{mi}\end{array}$ & $\begin{array}{c}\text { NMHC } \\
\mathrm{g} / \mathrm{mi}\end{array}$ & $\begin{array}{c}\mathrm{CO} \\
\mathrm{g} / \mathrm{mi}\end{array}$ & $\begin{array}{l}\mathrm{NO}_{\mathrm{x}} \\
\mathrm{g} / \mathrm{mi}\end{array}$ & $\begin{array}{c}\mathrm{PM} \\
\mathrm{mg} / \mathrm{mi}\end{array}$ & $\begin{array}{l}\text { THC } \\
\mathrm{g} / \mathrm{mi}\end{array}$ & $\begin{array}{c}\mathrm{NMHC} \\
\mathrm{g} / \mathrm{mi}\end{array}$ & $\begin{array}{l}\mathrm{CO} \\
\mathrm{g} / \mathrm{mi}\end{array}$ & $\begin{array}{l}\mathrm{NO}_{\mathrm{x}} \\
\mathrm{g} / \mathrm{mi}\end{array}$ & $\begin{array}{c}\mathrm{PM} \\
\mathrm{mg} / \mathrm{mi}\end{array}$ & $\begin{array}{l}\text { THC } \\
\mathrm{g} / \mathrm{mi}\end{array}$ & $\begin{array}{c}\text { NMHC } \\
\mathrm{g} / \mathrm{mi}\end{array}$ & $\begin{array}{l}\mathrm{CO} \\
\mathrm{g} / \mathrm{mi}\end{array}$ & $\begin{array}{l}\mathrm{NO}_{\mathrm{x}} \\
\mathrm{g} / \mathrm{mi}\end{array}$ & $\begin{array}{c}\mathrm{PM} \\
\mathrm{mg} / \mathrm{mi}\end{array}$ & $\begin{array}{l}\text { THC } \\
\mathrm{g} / \mathrm{mi}\end{array}$ & $\begin{array}{c}\text { NMHC } \\
\mathrm{g} / \mathrm{mi}\end{array}$ & $\begin{array}{l}\mathrm{CO} \\
\mathrm{g} / \mathrm{mi}\end{array}$ & $\begin{array}{l}\mathrm{NO}_{\mathrm{x}} \\
\mathrm{g} / \mathrm{mi}\end{array}$ & $\begin{array}{l}\mathrm{PM} \\
\mathrm{mg} / \mathrm{mi}\end{array}$ \\
\hline & 0.875 & 0.816 & 5.973 & 0.865 & 9.06 & 0.055 & 0.032 & 0.577 & 0.189 & 0.44 & 0.146 & 0.111 & 1.864 & 0.317 & 0.94 & 0.250 & 0.216 & 2.047 & 0.364 & 2.36 \\
\hline RFG \#2 & 1.023 & 0.970 & 7.749 & 0.764 & 1.35 & 0.031 & 0.010 & 0.275 & 0.169 & 0.15 & 0.098 & 0.078 & 1.270 & 0.282 & 0.28 & 0.255 & 0.227 & 2.093 & 0.323 & 0.44 \\
\hline RFG \#3 & 1.308 & 1.250 & 6.941 & 0.870 & 4.21 & 0.037 & 0.010 & 0.505 & 0.153 & 0.34 & 0.121 & 0.121 & 1.535 & 0.194 & 1.09 & 0.322 & 0.297 & 2.117 & 0.312 & 1.35 \\
\hline RFG \#4 & 1.060 & 1.005 & 5.453 & 0.948 & 2.51 & 0.062 & 0.038 & 0.957 & 0.224 & 0.53 & 0.147 & 0.117 & 2.216 & 0.345 & 1.32 & 0.292 & 0.259 & 2.231 & 0.407 & 1.16 \\
\hline RFG \#5 & 1.029 & 0.969 & 6.952 & 0.945 & 2.49 & 0.061 & 0.038 & 0.964 & 0.223 & 0.55 & 0.133 & 0.101 & 2.225 & 0.379 & 0.46 & 0.281 & 0.248 & 2.548 & 0.415 & 0.92 \\
\hline Average & 1.059 & 1.002 & 6.613 & 0.878 & 3.92 & 0.049 & 0.025 & 0.655 & 0.191 & 0.40 & 0.129 & 0.105 & 1.822 & 0.303 & 0.82 & 0.280 & 0.249 & 2.207 & 0.364 & 1.25 \\
\hline
\end{tabular}


Figure 1. FTP Weighted Average Emission Results for CNG and RFG Dodge Caravans

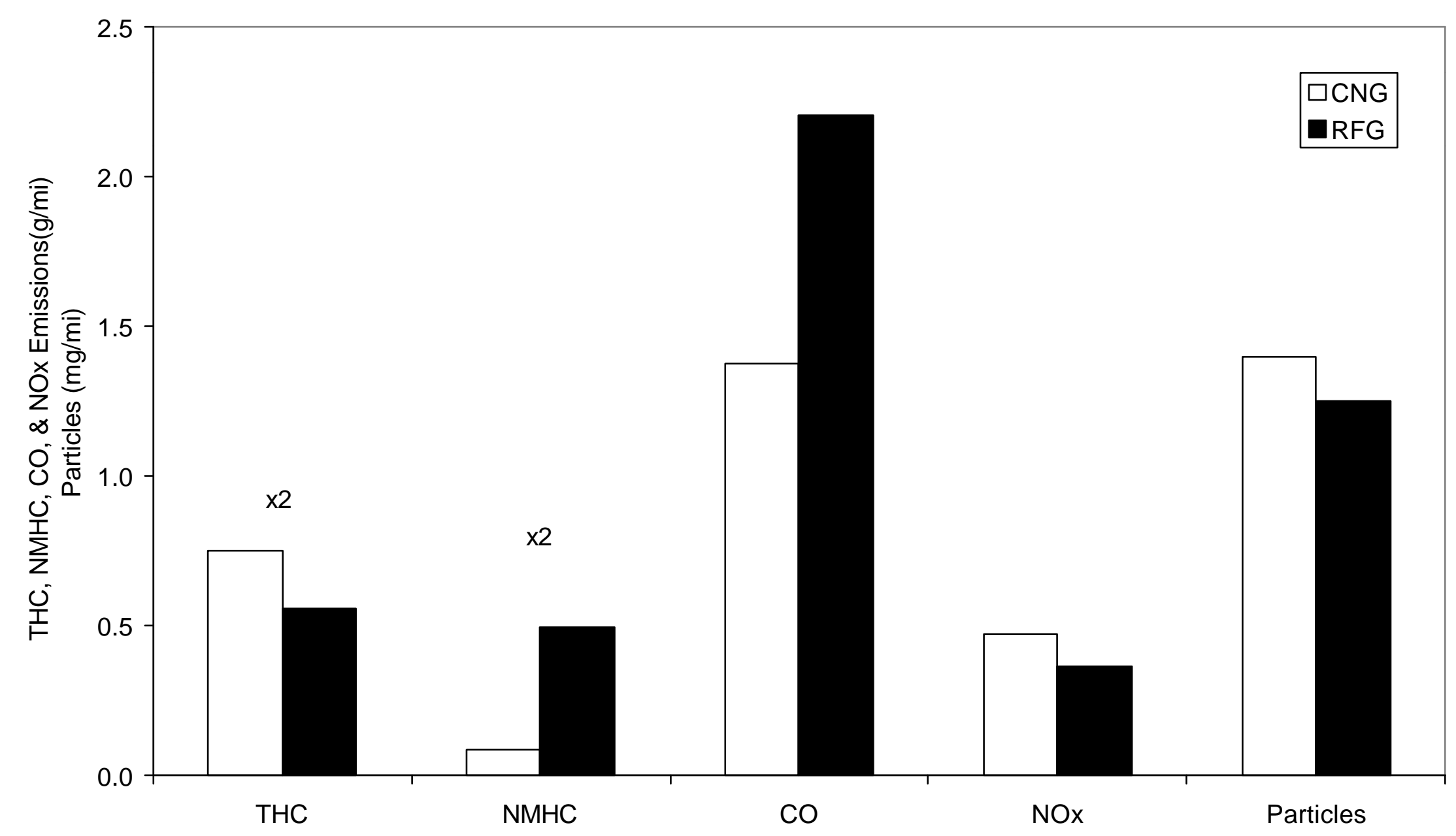


Figure 2. US06 Average Emission Results for CNG and RFG Caravans

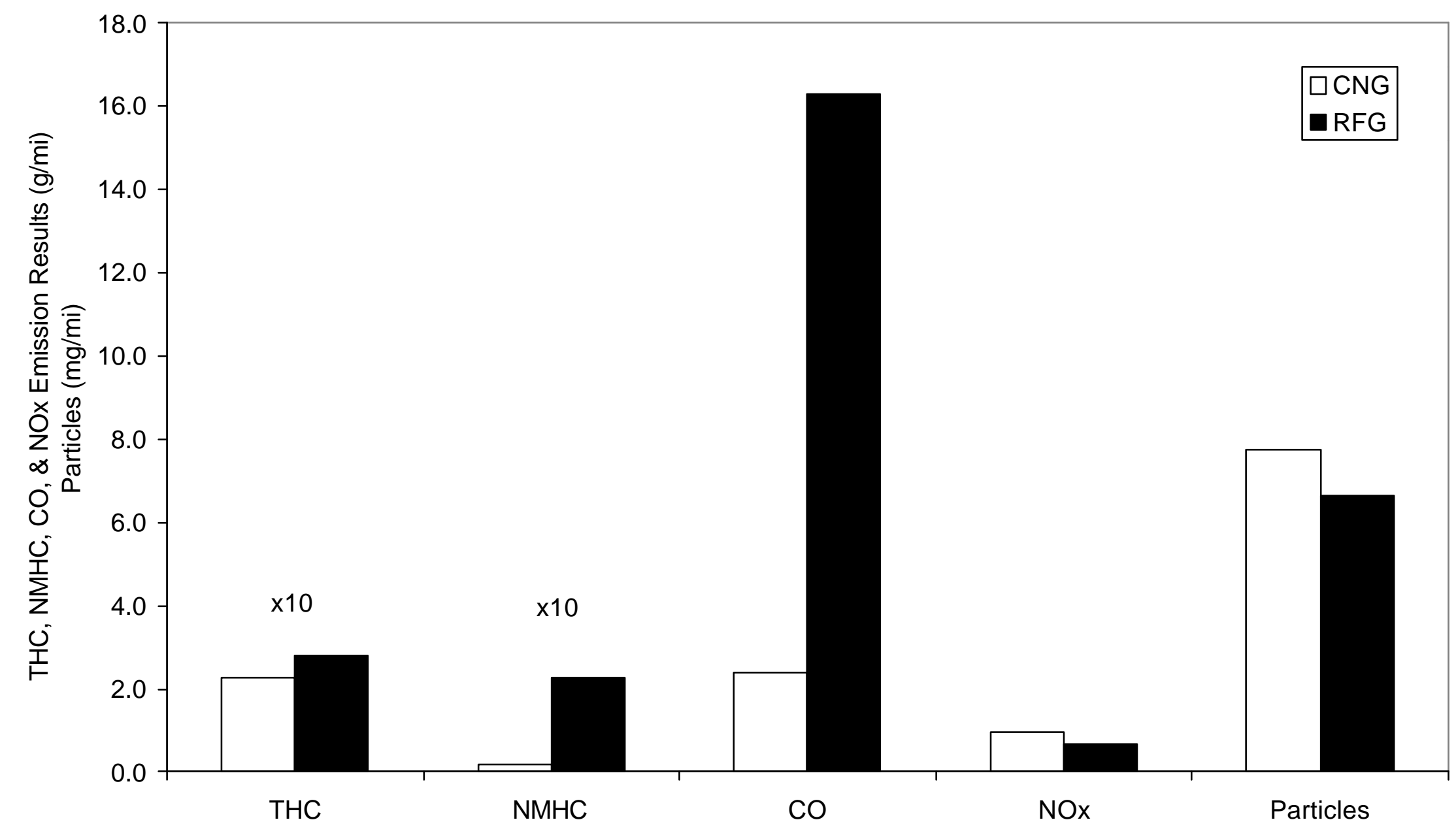


Table 3. US06 Average Emission Results for CNG and RFG Dodge Caravans

1994 CNG Dodge Caravans Results

\begin{tabular}{|l|ccccc|}
\hline & $\begin{array}{c}\mathrm{THC} \\
\mathrm{g} / \mathrm{mi}\end{array}$ & $\begin{array}{c}\mathrm{NMHC} \\
\mathrm{g} / \mathrm{mi}\end{array}$ & $\begin{array}{c}\mathrm{CO} \\
\mathrm{g} / \mathrm{mi}\end{array}$ & $\begin{array}{c}\mathrm{NO}_{\mathrm{x}} \\
\mathrm{g} / \mathrm{mi}\end{array}$ & $\begin{array}{c}\mathrm{PM} \\
\mathrm{mg} / \mathrm{mi}\end{array}$ \\
\cline { 2 - 6 }$\# 1$ & 0.577 & 0.055 & 6.685 & 3.134 & 12.46 \\
$\# 2$ & 0.173 & 0.012 & 1.806 & 0.622 & 5.24 \\
$\# 3$ & 0.118 & 0.003 & 1.515 & 0.254 & 4.74 \\
$\# 4$ & 0.145 & 0.007 & 0.423 & 0.458 & 13.77 \\
$\#$ 5 & 0.122 & 0.008 & 1.432 & 0.335 & 2.60 \\
& & & & & \\
\hline Average & 0.227 & 0.017 & 2.372 & 0.961 & 7.76 \\
Average & 0.140 & 0.008 & 1.294 & 0.417 & 6.59 \\
Excluding & & & & & \\
Vehicle\#1 & & & & & \\
\hline
\end{tabular}

1994 RFG Dodge Caravans Results

\begin{tabular}{|l|ccccc|}
\hline & $\begin{array}{c}\text { THC } \\
\mathrm{g} / \mathrm{mi}\end{array}$ & $\begin{array}{c}\mathrm{NMHC} \\
\mathrm{g} / \mathrm{mi}\end{array}$ & $\begin{array}{c}\mathrm{CO} \\
\mathrm{g} / \mathrm{mi}\end{array}$ & $\begin{array}{c}\mathrm{NO}_{\mathrm{x}} \\
\mathrm{g} / \mathrm{mi}\end{array}$ & $\begin{array}{c}\mathrm{PM} \\
\mathrm{mg} / \mathrm{mi}\end{array}$ \\
\cline { 2 - 6 }$\#$ 1 & 0.236 & 0.194 & 9.085 & 0.712 & 7.99 \\
$\# 3$ & 0.160 & 0.126 & 10.760 & 0.487 & 1.83 \\
$\#$ 3 & 0.294 & 0.243 & 17.362 & 0.563 & 11.63 \\
$\# 5$ & 0.410 & 0.339 & 25.451 & 0.761 & 7.95 \\
& 0.290 & 0.238 & 18.780 & 0.878 & 3.74 \\
\hline Average & 0.278 & 0.228 & 16.288 & 0.680 & 6.63 \\
\hline
\end{tabular}

The FTP emissions results for the FFV Ford Tauruses are presented in Table 4 and Figure 3.

Particulate emission rates for the FFV Ford Tauruses were relatively low and near the detection limits for some vehicles, but were comparable for M85 and RFG. These particulate mass emission rates are also comparable to those observed for newer gasoline vehicles in CE-CERT's more comprehensive study of in-use vehicles (Norbeck, Durbin, and Truex, 1998). For gaseous emissions, the Ford Tauruses produced 27\% lower $\mathrm{NO}_{\mathrm{x}}$ and 36\% higher CO emissions on M85 than on RFG. Organic material hydrocarbon equivalent emissions (OMHCE), calculated using oxygenated carbon mass as $\mathrm{CH}_{1.85}$, were $38 \%$ higher on M85 than on RFG. Total hydrocarbons excluding methanol were lower for M85 than RFG, however. As expected, both methanol and formaldehyde emissions were considerably higher for M85 than for RFG. For the M85 vehicles, methanol emissions can primarily be attributed to Bag 1 cold-start emissions. FTP methanol and formaldehyde emissions results for the Ford Tauruses are presented in Table 5. 
Table 4. FTP Average Emission Results for FFV Ford Tauruses on M85 and RFG

\begin{tabular}{|c|c|c|c|c|c|c|c|c|c|c|c|c|c|c|c|c|c|c|c|c|}
\hline \multirow[b]{3}{*}{ M85 \#1 } & \multicolumn{5}{|c|}{ Bag 1} & \multicolumn{5}{|c|}{ Bag 2} & \multicolumn{5}{|c|}{ Bag 3} & \multicolumn{5}{|c|}{ Weighted } \\
\hline & $\begin{array}{c}\text { OMHCE } \\
\mathrm{g} / \mathrm{mi}\end{array}$ & $\begin{array}{l}\text { THC } \\
\mathrm{g} / \mathrm{mi}\end{array}$ & $\begin{array}{l}\mathrm{CO} \\
\mathrm{g} / \mathrm{mi}\end{array}$ & $\begin{array}{l}\mathrm{NO}_{\mathrm{x}} \\
\mathrm{g} / \mathrm{mi}\end{array}$ & $\begin{array}{c}\mathrm{PM} \\
\mathrm{mg} / \mathrm{mi}\end{array}$ & $\begin{array}{c}\text { OMHCE } \\
\mathrm{g} / \mathrm{mi}\end{array}$ & $\begin{array}{l}\mathrm{THC} \\
\mathrm{g} / \mathrm{mi}\end{array}$ & $\begin{array}{l}\mathrm{CO} \\
\mathrm{g} / \mathrm{mi}\end{array}$ & $\begin{array}{l}\mathrm{NO}_{\mathrm{x}} \\
\mathrm{g} / \mathrm{mi}\end{array}$ & $\begin{array}{c}\mathrm{PM} \\
\mathrm{mg} / \mathrm{mi}\end{array}$ & $\begin{array}{c}\text { OMHCE } \\
\mathrm{g} / \mathrm{mi}\end{array}$ & $\begin{array}{r}\mathrm{THC} \\
\mathrm{g} / \mathrm{mi}\end{array}$ & $\begin{array}{l}\mathrm{CO} \\
\mathrm{g} / \mathrm{mi}\end{array}$ & $\begin{array}{l}\mathrm{NO}_{\mathrm{x}} \\
\mathrm{g} / \mathrm{mi}\end{array}$ & $\begin{array}{c}\mathrm{PM} \\
\mathrm{mg} / \mathrm{mi}\end{array}$ & $\begin{array}{c}\text { OMHCE } \\
\mathrm{g} / \mathrm{mi}\end{array}$ & $\begin{array}{l}\text { THC } \\
\mathrm{g} / \mathrm{mi}\end{array}$ & $\begin{array}{l}\mathrm{CO} \\
\mathrm{g} / \mathrm{mi}\end{array}$ & $\begin{array}{l}\mathrm{NO}_{\mathrm{x}} \\
\mathrm{g} / \mathrm{mi}\end{array}$ & $\begin{array}{c}\mathrm{PM} \\
\mathrm{mg} / \mathrm{mi}\end{array}$ \\
\hline & 0.716 & 0.335 & 6.372 & 0.451 & 0.77 & 0.025 & 0.019 & 1.619 & 0.199 & 0.06 & 0.057 & 0.034 & 2.005 & 0.317 & 0.26 & 0.177 & 0.088 & 2.709 & 0.284 & 0.26 \\
\hline M85 \#2 & 0.604 & 0.247 & 5.645 & 0.346 & 1.44 & 0.033 & 0.029 & 0.478 & 0.165 & 0.70 & 0.035 & 0.030 & 0.949 & 0.220 & 0.30 & 0.152 & 0.074 & 1.675 & 0.218 & 0.75 \\
\hline M85 \#3 & 0.777 & 0.258 & 5.775 & 0.372 & 0.53 & 0.034 & 0.023 & 0.824 & 0.167 & 0.56 & 0.056 & 0.046 & 1.940 & 0.177 & 0.27 & 0.194 & 0.078 & 2.152 & 0.212 & 0.47 \\
\hline M85 \#4 & 0.674 & 0.266 & 6.868 & 0.373 & 2.69 & 0.021 & 0.014 & 1.001 & 0.175 & 0.94 & 0.052 & 0.040 & 1.567 & 0.253 & 1.01 & 0.165 & 0.073 & 2.369 & 0.238 & 1.32 \\
\hline M85 \#5 & 1.086 & 0.352 & 9.286 & 0.151 & 1.26 & 0.025 & 0.016 & 1.110 & 0.058 & 0.50 & 0.029 & 0.024 & 1.807 & 0.114 & 0.69 & 0.245 & 0.088 & 2.995 & 0.093 & 0.71 \\
\hline Average & 0.772 & 0.309 & 6.789 & 0.338 & 1.35 & 0.028 & 0.021 & 1.006 & 0.153 & 0.57 & 0.050 & 0.038 & 1.653 & 0.216 & 0.52 & 0.187 & 0.080 & 2.380 & 0.209 & 0.70 \\
\hline
\end{tabular}

\begin{tabular}{|c|c|c|c|c|c|c|c|c|c|c|c|c|c|c|c|c|c|c|c|c|}
\hline \multirow[b]{3}{*}{ RFG \#1 } & \multicolumn{5}{|c|}{ Bag 1} & \multicolumn{5}{|c|}{ Bag 2} & \multicolumn{5}{|c|}{ Bag 3} & \multicolumn{5}{|c|}{ Weighted } \\
\hline & $\begin{array}{c}\text { OMHCE } \\
\mathrm{g} / \mathrm{mi}\end{array}$ & $\begin{array}{l}\text { THC } \\
\mathrm{g} / \mathrm{mi}\end{array}$ & $\begin{array}{l}\mathrm{CO} \\
\mathrm{g} / \mathrm{mi}\end{array}$ & $\begin{array}{l}\mathrm{NO}_{\mathrm{x}} \\
\mathrm{g} / \mathrm{mi}\end{array}$ & $\begin{array}{c}\mathrm{PM} \\
\mathrm{mg} / \mathrm{mi}\end{array}$ & $\begin{array}{c}\text { OMHCE } \\
\mathrm{g} / \mathrm{mi}\end{array}$ & $\begin{array}{l}\text { THC } \\
\mathrm{g} / \mathrm{mi}\end{array}$ & $\begin{array}{l}\mathrm{CO} \\
\mathrm{g} / \mathrm{mi}\end{array}$ & $\begin{array}{l}\mathrm{NO}_{\mathrm{x}} \\
\mathrm{g} / \mathrm{mi}\end{array}$ & $\begin{array}{c}\mathrm{PM} \\
\mathrm{mg} / \mathrm{mi}\end{array}$ & $\begin{array}{c}\text { OMHCE } \\
\mathrm{g} / \mathrm{mi}\end{array}$ & $\begin{array}{l}\mathrm{THC} \\
\mathrm{g} / \mathrm{mi}\end{array}$ & $\begin{array}{l}\mathrm{CO} \\
\mathrm{g} / \mathrm{mi}\end{array}$ & $\begin{array}{l}\mathrm{NO}_{x} \\
\mathrm{~g} / \mathrm{mi}\end{array}$ & $\begin{array}{c}\mathrm{PM} \\
\mathrm{mg} / \mathrm{mi}\end{array}$ & $\begin{array}{c}\text { OMHCE } \\
\mathrm{g} / \mathrm{mi}\end{array}$ & $\begin{array}{l}\mathrm{THC} \\
\mathrm{g} / \mathrm{mi}\end{array}$ & $\begin{array}{l}\mathrm{CO} \\
\mathrm{g} / \mathrm{mi}\end{array}$ & $\begin{array}{l}\mathrm{NO}_{\mathrm{x}} \\
\mathrm{g} / \mathrm{mi}\end{array}$ & $\begin{array}{c}\mathrm{PM} \\
\mathrm{mg} / \mathrm{m}\end{array}$ \\
\hline & 0.648 & 0.640 & 5.808 & 0.641 & 0.55 & 0.021 & 0.020 & 0.838 & 0.161 & 0.09 & 0.089 & 0.089 & 1.327 & 0.502 & 0.05 & 0.169 & 0.167 & 2.000 & 0.354 & 0.17 \\
\hline RFG \#2 & 0.479 & 0.473 & 6.370 & 0.415 & 1.78 & 0.010 & 0.009 & 0.128 & 0.132 & 0.13 & 0.032 & 0.032 & 0.371 & 0.299 & 0.03 & 0.113 & 0.111 & 1.491 & 0.237 & 0.45 \\
\hline RFG \#3 & 0.513 & 0.507 & 5.740 & 0.533 & 1.09 & 0.019 & 0.018 & 0.451 & 0.180 & 0.33 & 0.076 & 0.076 & 0.953 & 0.340 & 0.44 & 0.137 & 0.135 & 1.680 & 0.297 & 0.52 \\
\hline RFG \#4 & 0.604 & 0.595 & 5.413 & 0.469 & 2.53 & 0.011 & 0.008 & 0.736 & 0.163 & 2.00 & 0.080 & 0.079 & 0.908 & 0.355 & 0.49 & 0.152 & 0.149 & 1.767 & 0.281 & 1.69 \\
\hline RFG \#5 & 0.420 & 0.413 & 5.981 & 0.479 & 0.68 & 0.016 & 0.015 & 0.624 & 0.136 & 0.41 & 0.043 & 0.043 & 0.967 & 0.353 & 0.32 & 0.107 & 0.104 & 1.826 & 0.266 & 0.44 \\
\hline Average & 0.533 & 0.526 & 5.862 & 0.507 & 1.33 & 0.015 & 0.014 & 0.555 & 0.154 & 0.59 & 0.064 & 0.064 & 0.905 & 0.370 & 0.27 & 0.136 & 0.133 & 1.753 & 0.287 & 0.65 \\
\hline
\end{tabular}

Note: $\mathrm{THC}=$ Total flame ionization detector (FID) hydrocarbons excluding methanol

$\mathrm{OMHCE}=$ calculated using the oxygenated carbon mass as $\mathrm{CH}_{1.85}$ 
Figure 3. FTP Weighted Average Emission Results for M85 and RFG FFV Ford Tauruses

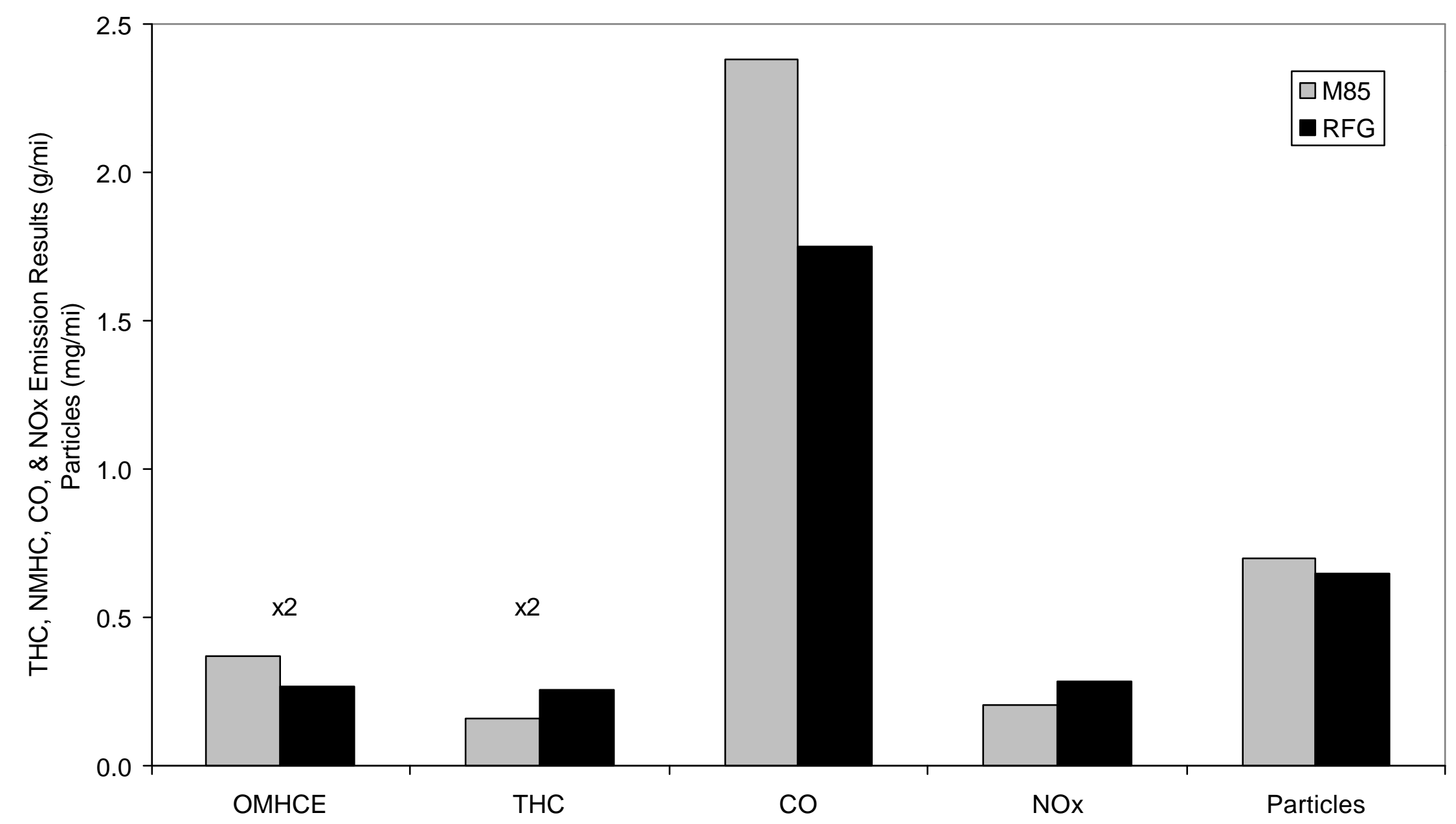


Table 5. FTP Methanol and Formaldehyde Results for Ford Tauruses on M85 and RFG

\begin{tabular}{|c|c|c|c|c|c|c|c|c|}
\hline \multicolumn{9}{|c|}{1994 FFV Ford Taurus (on M85) Results } \\
\hline & \multicolumn{2}{|c|}{ Bag 1} & \multicolumn{2}{|c|}{ Bag 2} & \multicolumn{2}{|c|}{ Bag 3} & \multicolumn{2}{|c|}{ Weighted } \\
\hline & $\begin{array}{c}\text { Methanol } \\
\mathrm{mg} / \mathrm{mi}\end{array}$ & $\begin{array}{c}\text { Formaldehyde } \\
\mathrm{mg} / \mathrm{mi}\end{array}$ & $\begin{array}{c}\text { Methanol } \\
\mathrm{mg} / \mathrm{mi}\end{array}$ & $\begin{array}{l}\text { Formaldehyde } \\
\mathrm{mg} / \mathrm{mi}\end{array}$ & $\begin{array}{c}\text { Methanol } \\
\mathrm{mg} / \mathrm{mi}\end{array}$ & $\begin{array}{l}\text { Formaldehyde } \\
\mathrm{mg} / \mathrm{mi}\end{array}$ & $\begin{array}{c}\text { Methanol } \\
\mathrm{mg} / \mathrm{mi}\end{array}$ & $\begin{array}{c}\text { Formaldehyde } \\
\mathrm{mg} / \mathrm{mi}\end{array}$ \\
\hline M85 \#1 & 825.7 & 49.7 & 1.8 & 11.0 & 51.8 & 2.2 & 185.6 & 16.6 \\
\hline M85 \#2 & 777.7 & 43.6 & 0.0 & 9.3 & 10.7 & 1.8 & 164.4 & 14.4 \\
\hline M85 \#3 & 1140.1 & 55.2 & 12.3 & 12.4 & 19.9 & 2.3 & 248.1 & 18.5 \\
\hline M85 \#4 & 248.1 & 54.6 & 2.4 & 12.5 & 26.1 & 2.0 & 191.2 & 18.3 \\
\hline M85 \#5 & 1585.9 & 103.2 & 5.1 & 13.2 & 10.4 & 1.5 & 332.8 & 28.6 \\
\hline Average & 915.5 & 61.3 & 4.3 & 11.7 & 23.8 & 2.0 & 224.4 & 19.3 \\
\hline
\end{tabular}

1994 FFV Ford Taurus (on RFG) Results

\begin{tabular}{|c|c|c|c|c|c|c|c|c|}
\hline \multirow[b]{3}{*}{ RFG \#1 } & \multicolumn{2}{|c|}{ Bag 1} & \multicolumn{2}{|c|}{ Bag 2} & \multicolumn{2}{|r|}{ Bag 3} & \multicolumn{2}{|c|}{ Weighted } \\
\hline & $\begin{array}{c}\text { Methanol } \\
\mathrm{mg} / \mathrm{mi}\end{array}$ & $\begin{array}{c}\text { Formaldehyde } \\
\mathrm{mg} / \mathrm{mi}\end{array}$ & $\begin{array}{l}\text { Methanol } \\
\mathrm{mg} / \mathrm{mi}\end{array}$ & $\begin{array}{l}\text { Formaldehyde } \\
\mathrm{mg} / \mathrm{mi}\end{array}$ & $\begin{array}{c}\text { Methanol } \\
\mathrm{mg} / \mathrm{mi}\end{array}$ & $\begin{array}{l}\text { Formaldehyde } \\
\mathrm{mg} / \mathrm{mi}\end{array}$ & $\begin{array}{c}\text { Methanol } \\
\mathrm{mg} / \mathrm{mi}\end{array}$ & $\begin{array}{c}\text { Formaldehyde } \\
\mathrm{mg} / \mathrm{mi}\end{array}$ \\
\hline & 7.4 & 9.1 & 0.0 & 2.7 & 0.0 & 1.3 & 1.5 & 3.6 \\
\hline RFG \#2 & 7.1 & 7.6 & 0.0 & 2.0 & 0.0 & 0.9 & 1.5 & 2.9 \\
\hline RFG \#3 & 5.4 & 7.8 & 0.0 & 2.8 & 0.0 & 0.8 & 1.1 & 3.3 \\
\hline RFG \#4 & 7.4 & 13.3 & 0.0 & 7.0 & 0.0 & 1.0 & 1.5 & 6.6 \\
\hline RFG \#5 & 10.9 & 6.0 & 0.0 & 1.8 & 0.0 & 0.5 & 2.3 & 2.3 \\
\hline Average & 7.6 & 8.8 & 0.0 & 3.3 & 0.0 & 0.9 & 1.6 & 3.7 \\
\hline
\end{tabular}

US06 emissions results are presented in Table 6 and Figure 4 for the FFV Ford Tauruses on M85 and RFG, respectively. Total and non-methane hydrocarbons are presented in these tables without correction for the FID response to methanol because these emissions were collected only on a limited number of US06 tests and not for all vehicles. $\mathrm{CO}, \mathrm{NO}_{\mathrm{x}}$, and $\mathrm{PM}$ were all higher for the US06 cycle than for the FTP. Increases relative to the FTP of $212 \%$ and $143 \%$ were observed for CO and $\mathrm{NO}_{\mathrm{x}}$, respectively, for M85 vehicles over the US06. US06 particulate emissions increased by a factor of 5-6 over the FTP, to $3.62 \mathrm{mg} / \mathrm{mi}$ for the M85 vehicles and $4.11 \mathrm{mg} / \mathrm{mi}$ for the RFG vehicles. Particulate emissions were comparable for M85 and RFG over the US06, while THC, NMHC, CO, and $\mathrm{NO}_{\mathrm{x}}$ emissions were all lower for M85 compared with RFG. The reductions for M85 relative to RFG were $68 \%, 72 \%, 33 \%$, and $44 \%$, respectively, for $\mathrm{THC}, \mathrm{NMHC}, \mathrm{CO}$, and $\mathrm{NO}_{\mathrm{x}}$. Methanol and formaldehyde emissions were very low for the US06 for both the M85 and RFG. 
Table 6. USO6 Average Emission Results for FFV Ford Tauruses on M85 and RFG

1994 FFV Ford Tauruses (on M85) Results

\begin{tabular}{|l|ccccccc|}
\hline & $\begin{array}{c}\mathrm{THC}^{*} \\
\mathrm{~g} / \mathrm{mi}\end{array}$ & $\begin{array}{c}\mathrm{NMHC}^{*} \\
\mathrm{~g} / \mathrm{mi}\end{array}$ & $\begin{array}{c}\mathrm{CO} \\
\mathrm{g} / \mathrm{mi}\end{array}$ & $\mathrm{NO}_{\mathrm{x}}$ & $\begin{array}{c}\mathrm{PM} \\
\mathrm{mg} / \mathrm{mi}\end{array}$ & $\begin{array}{c}\text { Methanol } \\
\mathrm{mg} / \mathrm{mi}\end{array}$ & $\begin{array}{c}\text { Formaldehyde } \\
\mathrm{mg} / \mathrm{mi}\end{array}$ \\
\cline { 2 - 8 }$\# 2$ & 0.019 & 0.016 & 2.395 & 0.947 & 2.91 & 0.0 & 6.0 \\
$\# 3 ~$ & 0.031 & 0.024 & 2.136 & 0.567 & 3.50 & 3.0 & 3.4 \\
$\# 4$ & 0.072 & 0.057 & 7.751 & 0.356 & 2.96 & - & - \\
$\#$ 5 & 0.050 & 0.038 & 5.615 & 0.466 & 1.63 & - & - \\
\hline Average & 0.083 & 0.057 & 19.234 & 0.201 & 7.08 & - & - \\
\hline
\end{tabular}

1994 FFV Ford Tauruses (on RFG) Results

\begin{tabular}{|l|ccccccc|}
\hline & $\begin{array}{c}\mathrm{THC}^{*} \\
\mathrm{~g} / \mathrm{mi}\end{array}$ & $\begin{array}{c}\mathrm{NMHC}^{*} \\
\mathrm{~g} / \mathrm{mi}\end{array}$ & $\begin{array}{c}\mathrm{CO} \\
\mathrm{g} / \mathrm{mi}\end{array}$ & $\mathrm{NO}_{\mathrm{x}}$ & $\begin{array}{c}\mathrm{PM} \\
\mathrm{mg} / \mathrm{mi}\end{array}$ & $\begin{array}{c}\text { Methanol } \\
\mathrm{mg} / \mathrm{mi}\end{array}$ & $\begin{array}{c}\text { Formaldehyde } \\
\mathrm{mg} / \mathrm{mi}\end{array}$ \\
\cline { 2 - 8 } \# 2 & 0.259 & 0.233 & 7.381 & 1.374 & 2.62 & 4.0 & 2.1 \\
$\# 3$ & 0.069 & 0.060 & 2.679 & 0.988 & 2.47 & 0.0 & 2.1 \\
$\# 4$ & 0.159 & 0.130 & 10.659 & 0.671 & 3.04 & - & - \\
$\#$ 5 & 0.138 & 0.116 & 8.935 & 0.788 & 4.12 & - & - \\
\hline Average & 0.182 & 0.136 & 25.449 & 0.672 & 8.32 & - & - \\
\hline
\end{tabular}

* uncorrected for response of FID to methanol

\subsection{Particle Size Distributions}

Average particulate size distributions for total mass below 10, 2.5, and $1.0 \mu \mathrm{m}$ aerodynamic diameter are presented in Figures 5 and 6, respectively, for the FTP and US06, along with the standard deviation between tests. Results for individual tests are presented in Appendix D. The results show that the majority of the particulate mass was below $10 \mu \mathrm{m}$ in aerodynamic diameter (77\%-92\%) with 58\%$82 \%$ of the mass below $2.5 \mu \mathrm{m}$, and $42 \%-77 \%$ below $1.0 \mu \mathrm{m}$. The fractions of mass in the smaller size regions, however, are generally less than those observed in other studies of smoking, diesel and gasoline vehicles (Durbin et al., 1999; Norbeck, Durbin, and Truex 1998; Whitney, 1998). In this regard, it is important to note that it is difficult to measure accurate size distributions from such low-emitting vehicles, because the mass collected on individual impaction substrates is often near or at the minimum detection limits $(\sim 4 \mu \mathrm{g})$. This problem has been noted in other studies (Whitney, 1997), and is indicated by the large errors associated with some test results, as presented in Appendix D. This is particularly relevant for the FTP testing with relatively low-mass emissions. It is also possible that the contribution of the reentrained particulate, which has been attributed to a coarse mode between 1 and $10 \mu \mathrm{m}$ in aerodynamic diameter (Marple et al., 1986), is greater for low-emitting vehicles or when vehicles are driven over more aggressive cycles. Appendix E presents a comparison of mass emission rates for the Teflon filters with those for the MOUDI. Differences in particulate mass emissions rates for the MOUDI and PTFE filters were generally less than $25 \%$. Particulate emission rates did differ by a factor of two or more, however, for some tests, with the greatest discrepancies observed for FTP tests with relatively lowmass emissions. 
Figure 4. US06 Average Emission Results for M85 and RFG FFV Ford Tauruses

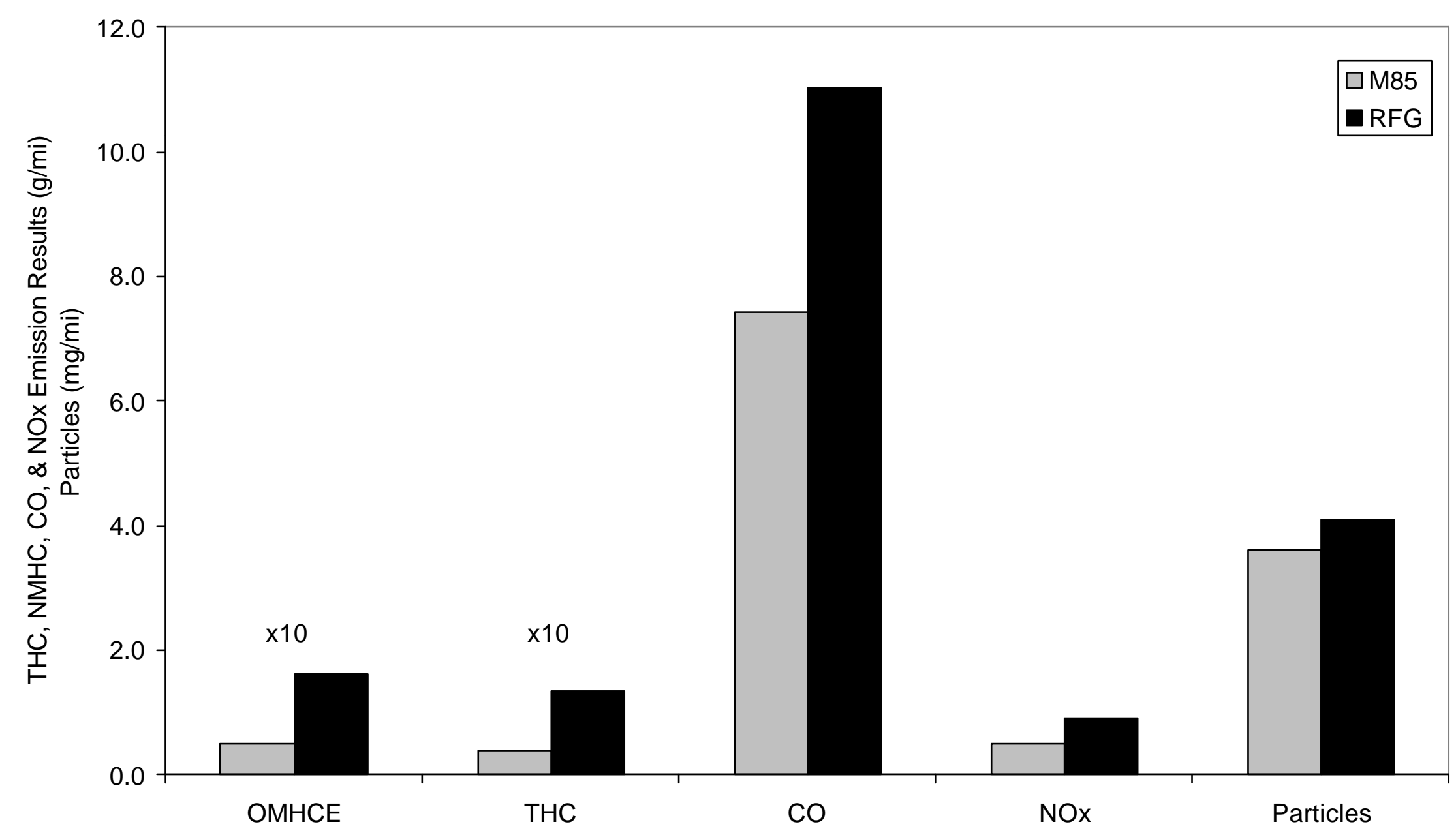


Figure 5. Average Particle Size Distributions for FTP

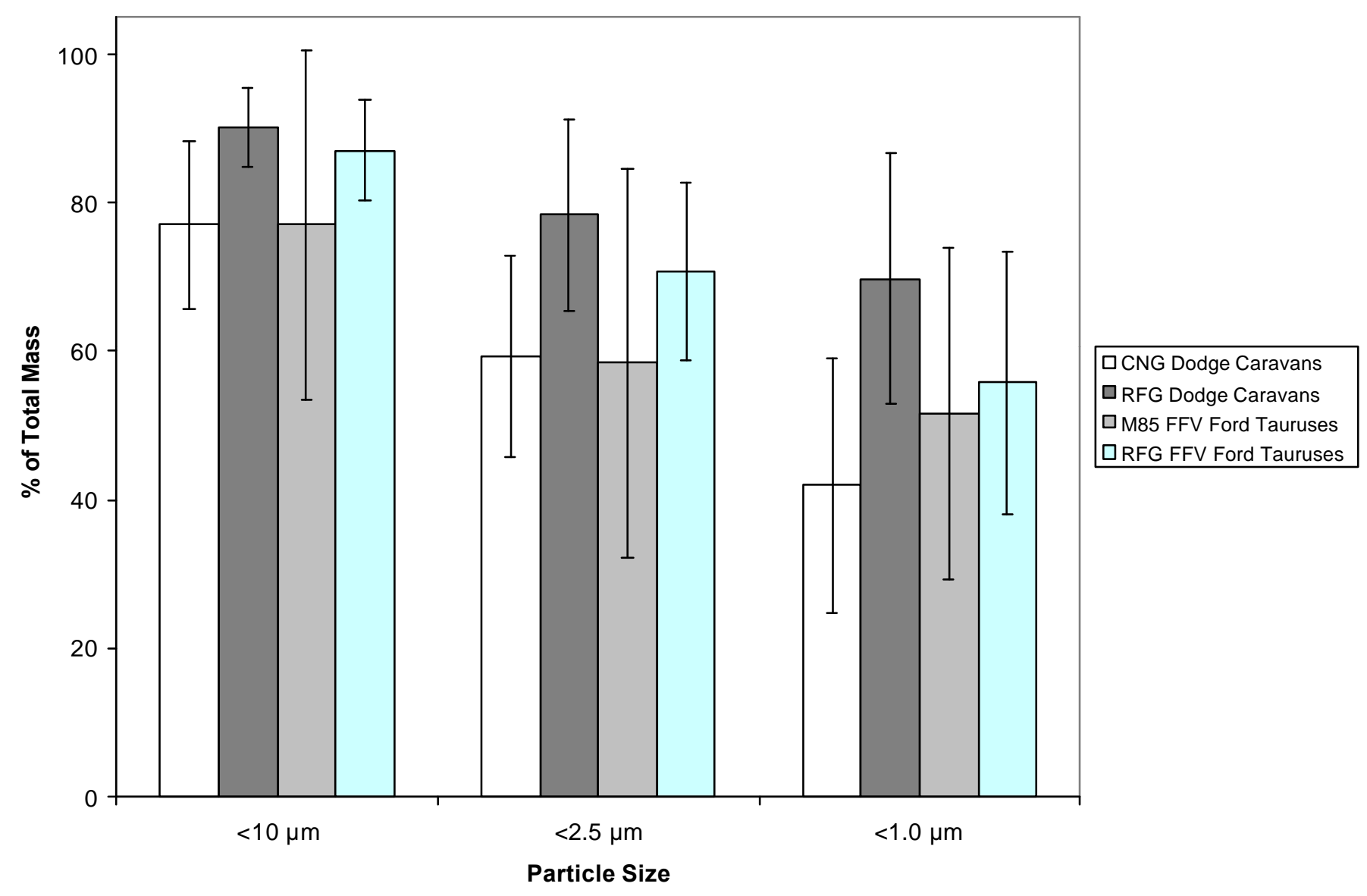


Figure 6. Average Particle Size Distributions for US06

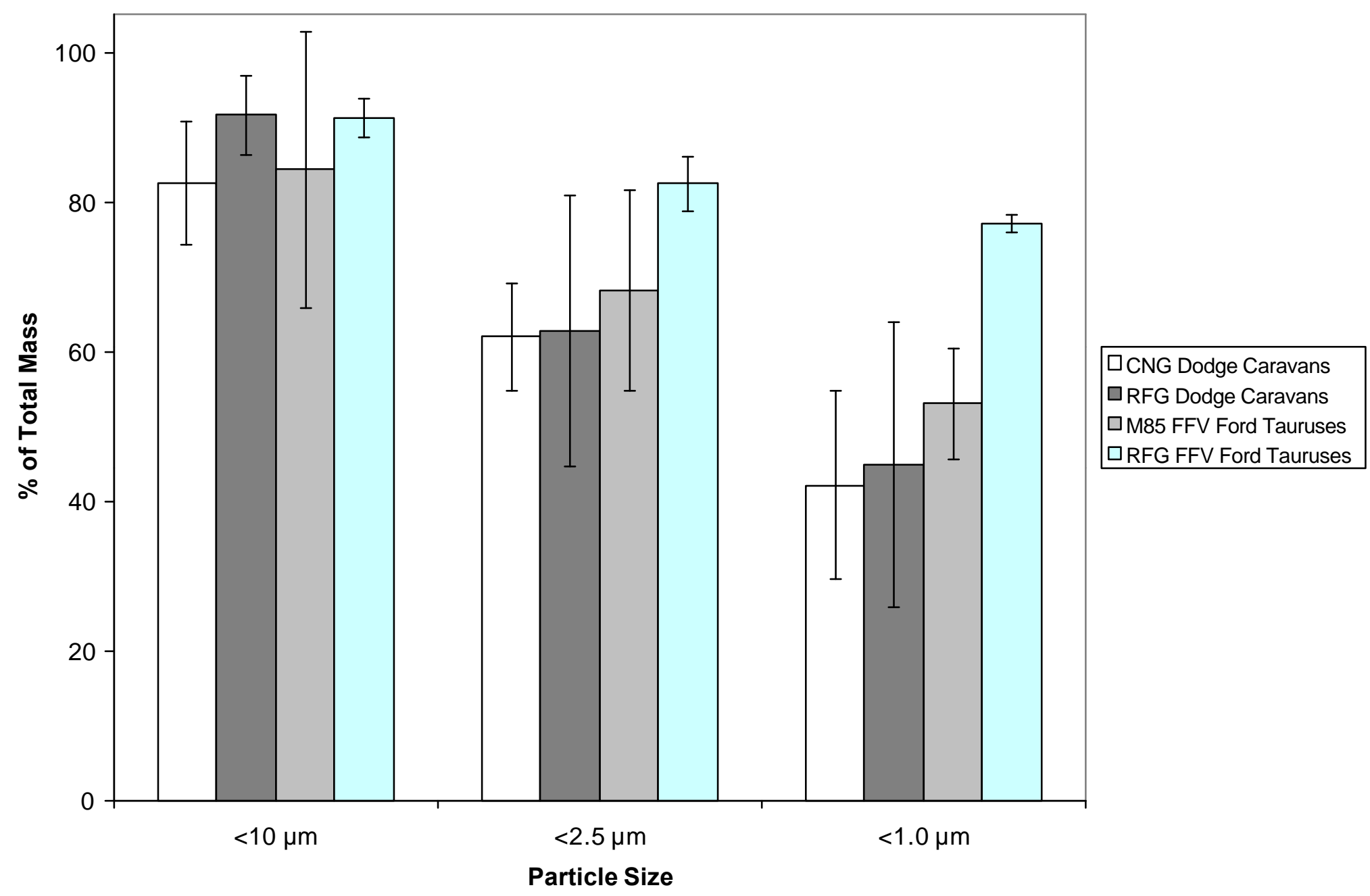




\subsection{Chemical Analysis Results and Discussion}

\subsection{Chemical Species}

Chemical analyses were conducted for samples from each fuel/vehicle group. The average FTP emission results for individual chemical species are presented in Table 7 and Figure 7 for the CNG/RFG Dodge Caravans and in Table 8 and Figure 8 for the M85/RFG Ford Tauruses. The average US06 emission results for individual chemical species are presented in Table 9 and Figure 9 for the CNG and RFG Dodge Caravans and in Table 10 and Figure 10 for the M85 and RFG Ford Tauruses. Tables 710 include average emission rates, standard deviations of the rates, maximum and minimum values, and average uncertainties for the FTP. The emission rates are corrected for the contribution of trace species detected in the dilution tunnel, and as a result, include some negative values. The error for each measurement is calculated by propagating the uncertainty for the chemical analysis and sampling volumes. Chemical components whose concentrations are at least twice the average uncertainty are shown in bold. Only chemical species with concentrations that were at least twice the average uncertainty for at least one fuel/vehicle group are presented in Figures 7-10. Full chemical analysis results for individual vehicle tests are presented in Appendices F and G, respectively, for the FTP and US06.

For the FTP, emission rates for the individual chemical species are all relatively low. Elemental and organic carbon are prominent species observed for the CNG, RFG, and M85 vehicles. It should be noted, however, that average organic carbon emissions are only greater than twice the average uncertainty for the CNG Dodge Caravans because of the high blank levels of organic carbon. Other species with average concentrations that were at least twice the average uncertainty include $\mathrm{NO}_{3}{ }^{-}, \mathrm{SO}_{4}{ }^{2-}$ , $\mathrm{Mg}, \mathrm{Al}, \mathrm{Si}, \mathrm{P}, \mathrm{S}, \mathrm{Cl}, \mathrm{Ca}, \mathrm{Fe}, \mathrm{Cu}$, and $\mathrm{Zn}$. These species include possible fuel derived $\left(\mathrm{SO}_{4}{ }^{2-}, \mathrm{S}\right)$ and oil- (Mg, P, Ca, Zn) and wear- (Fe, $\mathrm{Al})$ derived components, most of which have been observed in previous studies (Cadle et al., 1997; Sagebiel et al., 1997, Hildemann, Markowski, and Cass, 1991, and Watson et al., 1994). These elements are all observed in trace quantities, however, with emissions levels exceeding $0.05 \mathrm{mg} / \mathrm{mi}$ for only the RFG Dodge Caravans.

The chemical species emission levels are higher for the US06, as expected based on the mass emission rates. Elemental and organic carbon were again prominent constituents of the particulate for the US06 cycles. Other species identified at least twice the average uncertainty for at least one of the vehicle fuel groups include $\mathrm{NO}_{3}{ }^{-}, \mathrm{SO}_{4}{ }^{2-}, \mathrm{Cl}, \mathrm{NH}_{4}{ }^{+}, \mathrm{Mg}, \mathrm{Al}, \mathrm{Si}, \mathrm{P}, \mathrm{S}, \mathrm{Cl}, \mathrm{K}, \mathrm{Ca}, \mathrm{Cr}, \mathrm{Mn}, \mathrm{Fe}, \mathrm{Ni}, \mathrm{Cu}, \mathrm{Zn}, \mathrm{Br}, \mathrm{Zr}$, and $\mathrm{Pb}$. This includes many of the same elements identified for the FTP tests. Si emissions rates were relatively high for the US06 cycle. The Si mass emission rates are similar to those observed in the Orange County Remote Sensing study (Cadle et al., 1997), where the average pre-repair emission rate of elemental Si was $1.27 \mathrm{mg} / \mathrm{mi}(0.65 \mathrm{mg} / \mathrm{mi}$ with outliers removed). Fe emissions rates were also prominent for the CNG and RFG Dodge Caravans indicating a wear-derived contribution to the particulate. 
Figure 7. PM Chemical Mass Emission Rates for CNG/RFG Dodge Caravans for FTP

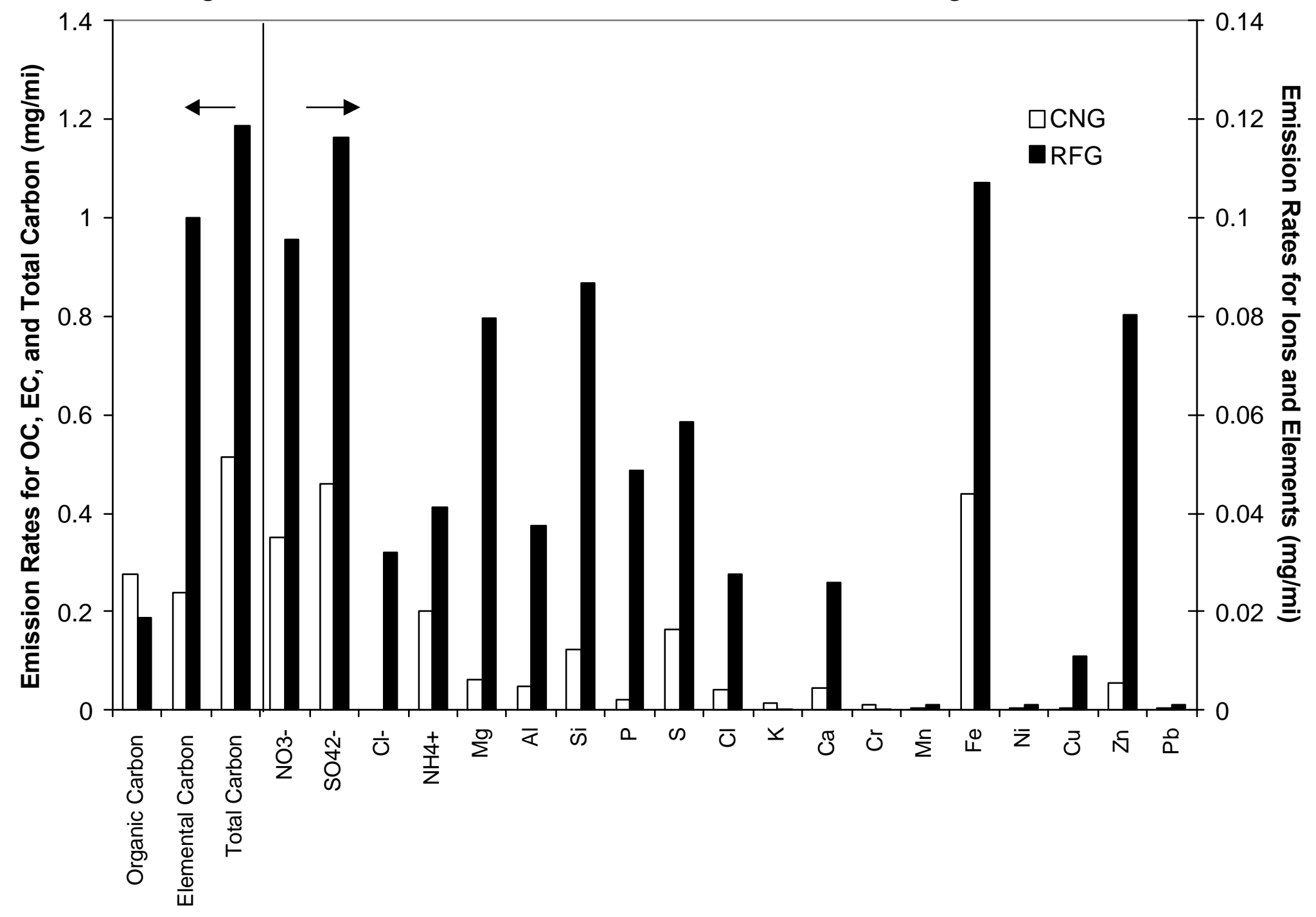


Figure 8. PM Chemical Mass Emission Rates for M85/RFG Ford Tauruses for FTP

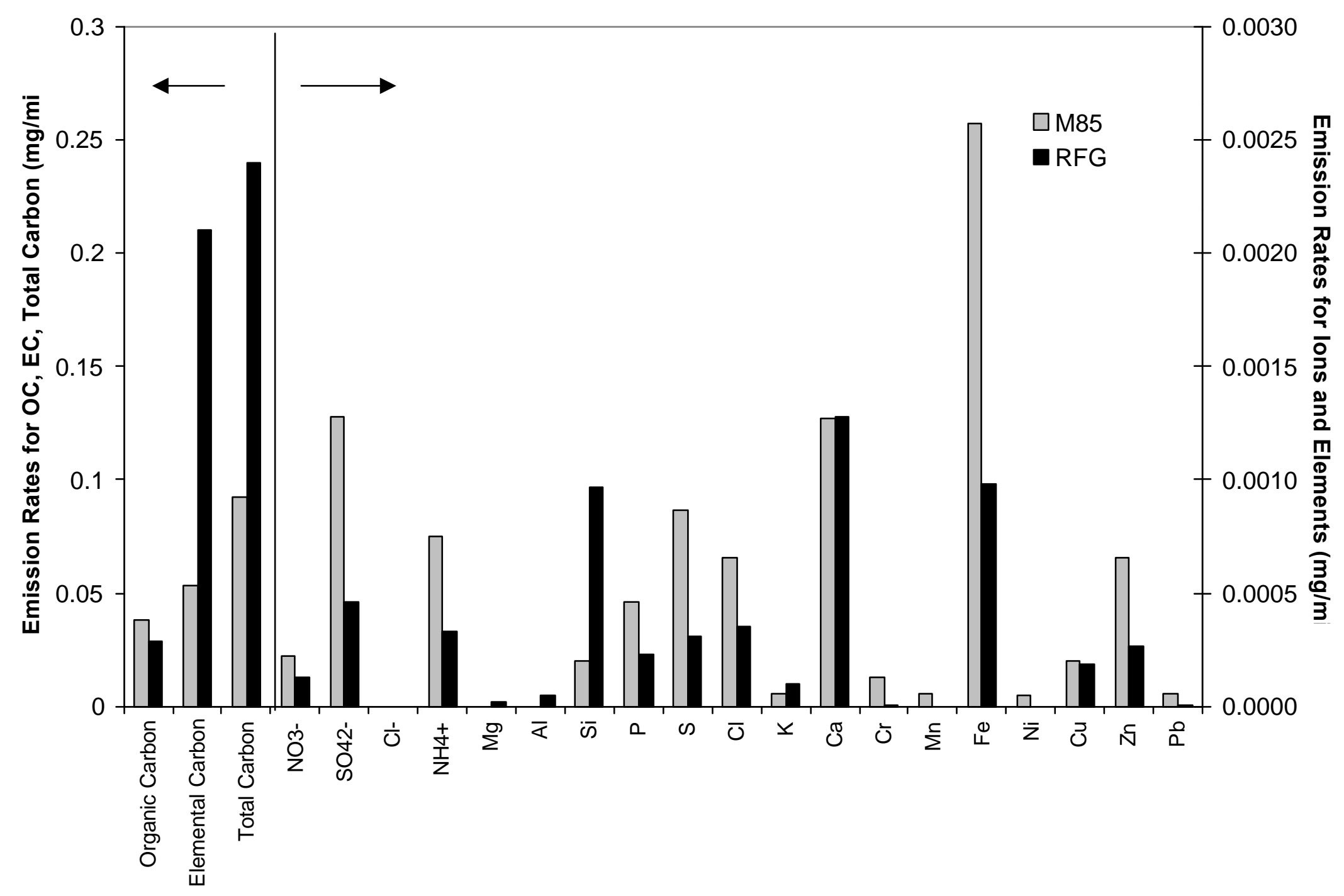


Figure 9. PM Chemical Mass Emission Rates for CNG/RFG Dodge Caravans for US06

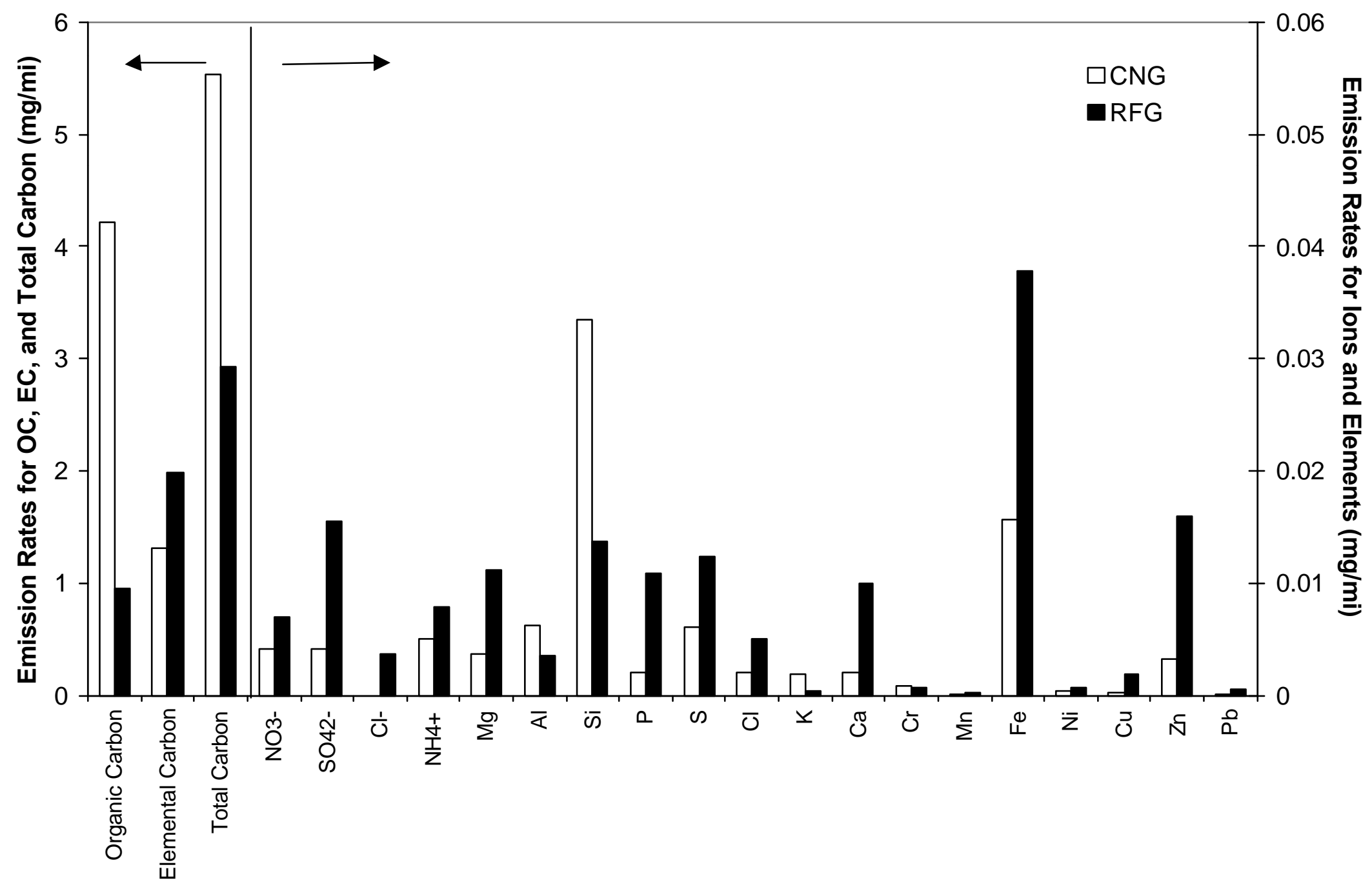


Figure 10. PM Chemical Mass Emission Rates for M85/RFG Ford Tauruses

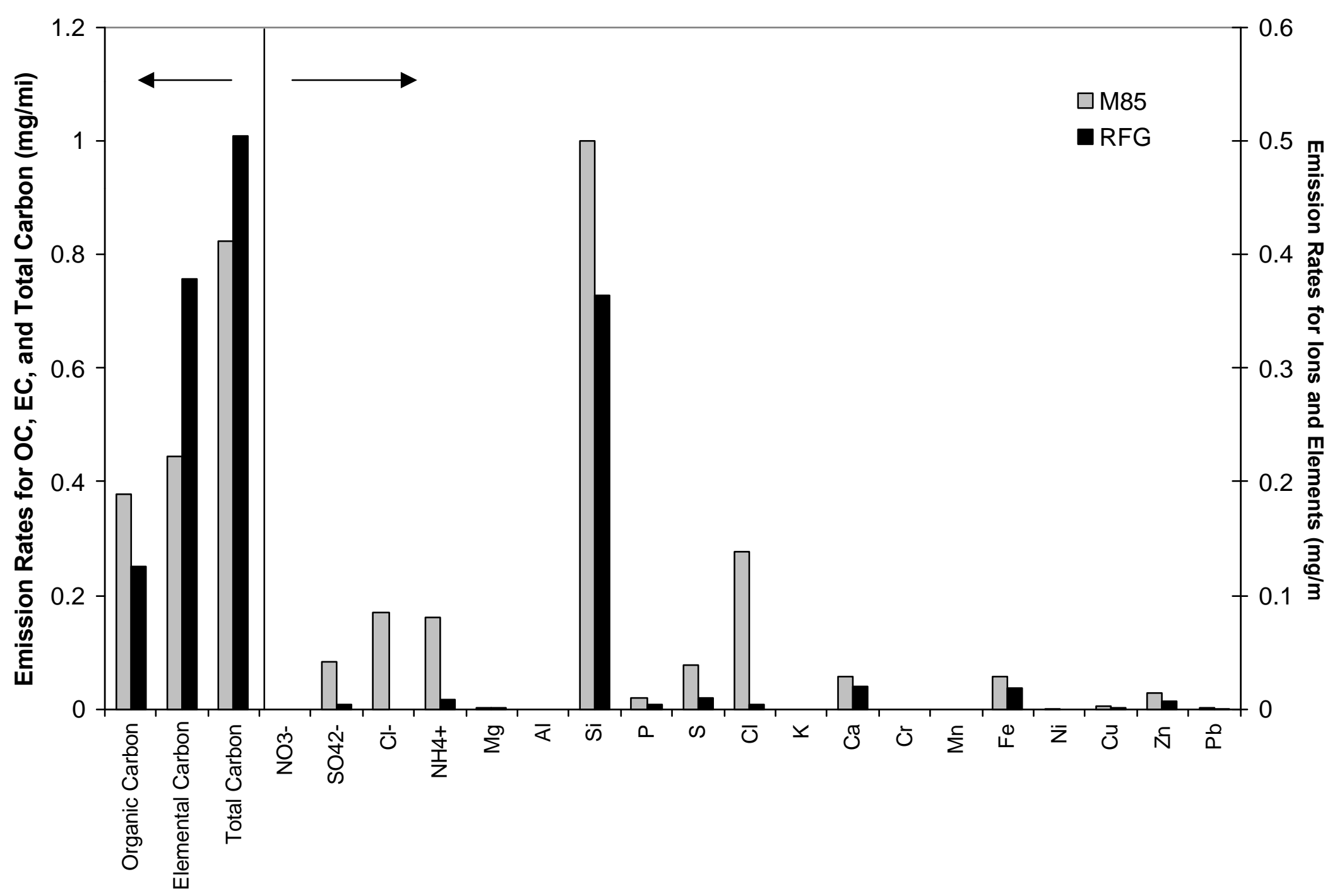


Table 7. Statistics for CNG and RFG Dodge Caravans for FTP PM Chemical Species Emission Rates (mg/mi)

\begin{tabular}{|c|c|c|c|c|c|c|c|c|c|c|}
\hline \multirow[b]{2}{*}{ Species } & \multicolumn{5}{|c|}{ CNG Dodge Caravans } & \multicolumn{5}{|c|}{ RFG Dodge Caravans } \\
\hline & Avg. & St. Dev. & $\begin{array}{l}\text { Avg. } \\
\text { Uncert. }\end{array}$ & Max. & Min. & Avg. & St. Dev. & $\begin{array}{l}\text { Avg. } \\
\text { Uncert. }\end{array}$ & Max. & Min. \\
\hline Organic Carbon & 0.2777 & 0.2585 & 0.1095 & 0.6870 & 0.0034 & 0.1875 & 0.3523 & 0.1033 & 0.7405 & -0.1465 \\
\hline Elemental Carbon & 0.2376 & 0.2591 & 0.0381 & 0.6768 & -0.0001 & 0.9998 & 0.9358 & 0.1021 & 2.5819 & 0.2865 \\
\hline Total Carbon & .5153 & 0.4053 & 0.1299 & 0.9230 & 0.0033 & 1.1876 & 1.2840 & 0.1728 & 3.3239 & 0.1400 \\
\hline $\mathrm{NO}_{3}^{-}$ & 0.0351 & 0.0363 & 0.0156 & 0.0942 & -0.0044 & 0.0955 & 0.2049 & 0.0343 & 0.4612 & -0.0135 \\
\hline $\mathrm{SO}_{4}{ }^{2-}$ & 0.0459 & 0.0576 & 0.0153 & 0.1483 & 0.0144 & 0.1162 & 0.2363 & 0.0336 & 0.5380 & -0.0104 \\
\hline $\mathrm{Cl}^{-}$ & .0015 & 0.0040 & 0.0134 & 0.0033 & -0.0059 & 0.0321 & 0.0880 & 0.0314 & 0.1896 & -0.0100 \\
\hline $\mathrm{NH}_{4}^{+}$ & 0.0203 & 0.0167 & 0.0136 & 0.0493 & 0.0079 & 0.0411 & 0.0717 & 0.0311 & 0.1687 & 0.0037 \\
\hline $\mathrm{Na}$ & -0.0019 & 0.0043 & 0.0250 & 0.0030 & -0.0063 & -0.0047 & 0.0035 & 0.0831 & 0.0016 & -0.0063 \\
\hline $\mathrm{Mg}$ & 0.0063 & 0.0087 & 0.0083 & 0.0217 & 0.0003 & 0.0798 & 0.1724 & 0.0174 & 0.3882 & 0.0006 \\
\hline $\mathrm{Al}$ & 0.0049 & 0.0058 & 0.0038 & 0.0113 & -0.0005 & 0.0376 & 0.0791 & 0.0079 & 0.1791 & 0.0002 \\
\hline $\mathrm{Si}$ & 0.0124 & 0.0114 & 0.0018 & 0.0294 & 0.0020 & 0.0868 & 0.1859 & 0.0094 & 0.4193 & .0004 \\
\hline $\mathrm{P}$ & 0.0020 & 0.0025 & 0.0012 & 0.0060 & -0.0007 & 0.0488 & 0.0987 & 0.0057 & 0.2253 & .0003 \\
\hline S & 0.0165 & 0.0144 & 0.0018 & 0.0414 & 0.0067 & 0.0584 & 0.1160 & 0.0060 & 0.2658 & 0.0011 \\
\hline $\mathrm{Cl}$ & 0.0043 & 0.0037 & 0.0028 & 0.0105 & 0.0017 & 0.0276 & 0.0559 & 0.0056 & 0.1276 & 0.0001 \\
\hline K & 0.0016 & 0.0022 & 0.0023 & 0.0042 & -0.0014 & 0.0001 & 0.0019 & 0.0087 & 0.0034 & -0.0009 \\
\hline $\mathrm{Ca}$ & 0.0046 & 0.0049 & 0.0018 & 0.0131 & 0.0012 & 0.0260 & 0.0388 & 0.0042 & 0.0947 & 0.0008 \\
\hline $\mathrm{Ti}$ & 0.0008 & 0.0007 & 0.0129 & 0.0019 & 0.0000 & 0.0024 & .0044 & 0.0308 & 0.0103 & .0000 \\
\hline V & 0.0003 & 0.0003 & 0.0061 & 0.0009 & 0.00 & 0.0016 & .0032 & 0.0129 & 0.0073 & .0000 \\
\hline $\mathrm{Cr}$ & 0.0010 & 0.0012 & 0.0017 & 0.0029 & 0.0000 & 0.0002 & 0.0003 & 0.0035 & 0.0006 & 0.0000 \\
\hline $\mathrm{Mn}$ & 0.0005 & 0.0004 & 0.0010 & 0.0009 & 0.0000 & 0.0010 & .0019 & 0.0025 & 0.0043 & -0.0001 \\
\hline $\mathrm{Fe}$ & 0440 & 0.0112 & 0.0040 & 0569 & 0.0274 & 0.1070 & 1798 & 0.0097 & 0.4284 & 0.0190 \\
\hline Co & .0001 & 0.0001 & 0.0010 & 0002 & 0.0000 & 0.0000 & .0000 & 0.0025 & 0.0000 & 0.0000 \\
\hline $\mathrm{Ni}$ & 0.0003 & 0.0006 & 0.0006 & 0013 & -0.0001 & 0.0011 & .0024 & 0.0017 & 0.0053 & -0.0001 \\
\hline $\mathrm{Cu}$ & 0.0003 & 0.0003 & 0.0006 & 0007 & 0.0000 & 0.0109 & 0231 & 0.0016 & .0523 & 0.0000 \\
\hline $\mathrm{Zn}$ & 0054 & 0.0037 & 0.0007 & 0.0111 & 0.0018 & 0.0804 & 1652 & 0.0074 & 0.3759 & 0.0010 \\
\hline $\mathrm{Ga}$ & .0001 & 0.0001 & 0.0010 & 0001 & -0.0002 & -0.0001 & .0000 & 0.0025 & -0.0001 & -0.0002 \\
\hline As & 0.0000 & 0.0000 & 0.0012 & 0000 & & & 0006 & 0.0030 & 0.0014 & 0.0000 \\
\hline $\mathrm{Se}$ & 0.0000 & 0.0000 & 0.0006 & 0.0001 & 0.0000 & 0.0000 & .0001 & 0.0015 & 0.0001 & 0.0000 \\
\hline $\mathrm{Br}$ & 0.0000 & 0.0001 & 0.0006 & 0.0001 & -0.0001 & 0.0002 & .0006 & 0.0014 & 0.0013 & -0.0001 \\
\hline $\mathrm{Rb}$ & .0001 & 0.0000 & 0.0005 & 0.0000 & -0.0001 & 0.0002 & .0005 & 0.0013 & 0.0011 & -0.0001 \\
\hline $\mathrm{Sr}$ & 0.0001 & 0.0001 & 0.0006 & 0.0002 & 0.0000 & 0.0000 & .0001 & 0.0014 & 0.0001 & 0.0000 \\
\hline Y & -0.0001 & 0.0001 & 0.0007 & 0.0000 & -0.0001 & 0.0005 & .0011 & 0.0018 & 0.0024 & -0.0001 \\
\hline $\mathrm{Zr}$ & 0.0001 & 0.0001 & 0.0008 & 0.0003 & & & .0011 & 0.0020 & 0.0024 & 0.0000 \\
\hline Mo & 0.0001 & 0.0001 & 0.0015 & 0.0002 & 0.0000 & & .0017 & 0.0038 & 0.0037 & 0.0000 \\
\hline $\mathrm{Pd}$ & 0.0007 & 0.0009 & 0.0043 & 0.0018 & 0.0000 & 0.0005 & .0006 & 0.0103 & 0.0013 & 0.0000 \\
\hline $\mathrm{Ag}$ & -0.0007 & 0.0007 & 0.0050 & 0.0002 & -0.0012 & 0.0063 & 0.0145 & 0.0124 & 0.0323 & -0.0010 \\
\hline $\mathrm{Cd}$ & -0.0002 & 0.0004 & 0.0051 & 0.0002 & -0.0007 & 0.0005 & 0.0013 & 0.0126 & 0.0025 & -0.0007 \\
\hline In & -0.0002 & 0.0007 & 0.0062 & 0.0010 & -0.0007 & 0.0048 & 0.0113 & 0.0153 & 0.0250 & -0.0007 \\
\hline $\mathrm{Sn}$ & 0.0003 & 0.0006 & 0.0080 & 0.0014 & 0.0000 & 0.0051 & 0.0107 & 0.0198 & 0.0242 & 0.0000 \\
\hline $\mathrm{Sb}$ & 0.0006 & 0.0006 & 0.0093 & 0.0014 & 0.0000 & 0.0092 & 0.0198 & 0.0227 & 0.0445 & 0.0000 \\
\hline $\mathrm{Ba}$ & .0113 & 0.0029 & 0.0343 & -0.0065 & -0.0132 & -0.0023 & 0.0224 & 0.0846 & 0.0378 & -0.0132 \\
\hline $\mathrm{La}$ & .0094 & 0.0086 & 0.0456 & 0.0060 & -0.0133 & -0.0004 & 0.0219 & 0.1118 & 0.0377 & -0.0133 \\
\hline $\mathrm{Au}$ & .0001 & 0.0002 & 0.0017 & 0.0002 & -0.0002 & -0.0002 & 0.0001 & 0.0054 & -0.0001 & -0.0002 \\
\hline $\mathrm{Hg}$ & .0002 & 0.0000 & 0.0014 & -0.0002 & -0.0002 & -0.0002 & 0.0000 & 0.0034 & -0.0002 & -0.0002 \\
\hline $\mathrm{Ti}$ & -0.0002 & 0.0000 & 0.0013 & -0.0002 & -0.0002 & -0.0002 & 0.0000 & 0.0032 & -0.0002 & -0.0002 \\
\hline $\mathrm{Pb}$ & 0.0005 & 0.0003 & 0.0017 & 0.0007 & 0.0000 & 0.0010 & 0.0021 & 0.0043 & 0.0047 & 0.0000 \\
\hline $\mathrm{U}$ & 0.0000 & 0.0001 & 0.0013 & 0.0001 & 0.0000 & 0.0007 & 0.0016 & 0.0031 & 0.0035 & 0.0000 \\
\hline
\end{tabular}


Table 8. Statistics for M85 and RFG Ford Tauruses for FTP PM Chemical Species Emission Rates (mg/mi)

\begin{tabular}{|c|c|c|c|c|c|c|c|c|c|c|}
\hline \multirow[b]{2}{*}{ Species } & \multicolumn{5}{|c|}{ M85 Ford Tauruses } & \multicolumn{5}{|c|}{ RFG Ford Tauruses } \\
\hline & Avg. & St. Dev. & $\begin{array}{l}\text { Avg. } \\
\text { Uncert. }\end{array}$ & Max. & Min. & Avg. & St. Dev. & $\begin{array}{l}\text { Avg. } \\
\text { Uncert. }\end{array}$ & Max. & Min. \\
\hline Organic Carbon & 0.0380 & 0.1106 & 0.1049 & 0.1813 & -0.1139 & 0.0292 & 0.2694 & 0.1037 & 0.4974 & -0.1405 \\
\hline Elemental Carbon & 0.0537 & 0.0540 & 0.0247 & 0.1255 & -0.0048 & 0.2104 & 0.1000 & 0.0285 & 0.3697 & 0.1283 \\
\hline Total Carbon & 0.0921 & 0.1628 & 0.1134 & 0.3068 & -0.1170 & 0.2395 & 0.3217 & 0.1135 & 0.7383 & -0.0079 \\
\hline $\mathrm{NO}_{3}^{-}$ & 0.0022 & 0.0109 & 0.0144 & 0.0175 & -0.0088 & 0.0013 & 0.0128 & 0.0141 & 0.0197 & -0.0136 \\
\hline $\mathrm{SO}_{4}{ }^{2-}$ & 0.0128 & 0.0220 & 0.0139 & 0.0374 & -0.0217 & 0.0046 & 0.0302 & 0.0136 & 0.0421 & -0.0267 \\
\hline $\mathrm{Cl}^{-}$ & -0.0035 & 0.0038 & 0.0134 & 0.0025 & -0.0073 & -0.0071 & 0.0023 & 0.0130 & -0.0045 & -0.0096 \\
\hline $\mathrm{NH}_{4}^{+}$ & 0.0075 & 0.0125 & 0.0137 & 0.0218 & -0.0116 & 0.0033 & 0.0141 & 0.0133 & 0.0238 & -0.0116 \\
\hline $\mathrm{Na}$ & 0.0102 & 0.0026 & 0.0222 & 0.0139 & 0.0065 & -0.0015 & 0.0042 & 0.0233 & 0.0039 & -0.0063 \\
\hline $\mathrm{Mg}$ & -0.0017 & 0.0027 & 0.0095 & 0.0025 & -0.0049 & 0.0002 & 0.0043 & 0.0088 & 0.0064 & -0.0054 \\
\hline $\mathrm{Al}$ & -0.0021 & 0.0011 & 0.0047 & -0.0007 & -0.0037 & 0.0005 & 0.0010 & 0.0038 & 0.0019 & -0.0007 \\
\hline $\mathrm{Si}$ & 0.0020 & 0.0029 & 0.0015 & 0.0050 & -0.0015 & 0.0097 & 0.0090 & 0.0014 & 0.0204 & 0.0020 \\
\hline $\mathrm{P}$ & 0.0046 & 0.0031 & 0.0012 & 0.0074 & -0.0005 & 0.0023 & 0.0016 & 0.0011 & 0.0045 & 0.0006 \\
\hline S & 0.0087 & 0.0082 & 0.0013 & 0.0174 & -0.0050 & 0.0031 & 0.0040 & 0.0010 & 0.0095 & -0.0009 \\
\hline $\mathrm{Cl}$ & 0.0066 & 0.0056 & 0.0028 & 0.0136 & 0.0008 & 0.0035 & 0.0030 & 0.0028 & 0.0087 & 0.0012 \\
\hline K & 0.0006 & 0.0010 & 0.0022 & 0.0019 & -0.0006 & 0.0010 & 0.0014 & 0.0022 & 0.0034 & -0.0003 \\
\hline $\mathrm{Ca}$ & 0.0127 & 0.0068 & 0.0021 & 0.0187 & 0.0024 & 0.0128 & 0.0061 & 0.0020 & 0.0229 & 0.0081 \\
\hline $\mathrm{Ti}$ & 0.0009 & 0.0009 & 0.0129 & 0.0019 & 0.0001 & 0.0010 & 0.0010 & 0.0127 & 0.0021 & 0.0000 \\
\hline V & 0.0001 & 0.0001 & 0.0062 & 0.0003 & 0.0000 & 0.0001 & 0.0002 & 0.0062 & 0.0004 & 0.0000 \\
\hline $\mathrm{Cr}$ & 0.0013 & 0.0024 & 0.0018 & 0.0056 & 0.0000 & 0.0001 & 0.0002 & 0.0018 & 0.0005 & 0.0000 \\
\hline $\mathrm{Mn}$ & 0.0006 & 0.0015 & 0.0011 & 0.0034 & -0.0001 & -0.0001 & 0.0000 & 0.0010 & 0.0000 & -0.0001 \\
\hline $\mathrm{Fe}$ & 0.0257 & 0.0084 & 0.0023 & 0.0346 & 0.0149 & 0.0098 & 0.0055 & 0.0011 & 0.0166 & 0.0042 \\
\hline Co & 0.0002 & 0.0001 & 0.0008 & 0004 & 0.0000 & 0.0000 & 0.0001 & 0.0007 & .0001 & 0.0000 \\
\hline $\mathrm{Ni}$ & 0.0005 & 0.0008 & 0.0006 & 0.0018 & 0.0000 & 0.0000 & 0.0001 & 0.0006 & 0.0001 & -0.0001 \\
\hline $\mathrm{Cu}$ & 0.0020 & 0.0012 & 0.0006 & 0.0035 & 0.0004 & 0.0019 & 0.0016 & 0.0006 & 0.0044 & 0.0000 \\
\hline $\mathrm{Zn}$ & 0066 & 0.0030 & 0.0008 & 0.0098 & 0.0025 & 0.0027 & 0.0010 & 0.0006 & 0.0041 & 0.0016 \\
\hline $\mathrm{Ga}$ & -0.0001 & 0.0001 & 0.0010 & 0.0000 & -0.0002 & -0.0002 & 0.0000 & 0.0010 & -0.0002 & -0.0002 \\
\hline As & 0.0000 & 0.0001 & 0.0012 & 0001 & & 0.0000 & 0.0000 & 0.0012 & 0.0001 & 0.0000 \\
\hline $\mathrm{Se}$ & 0.0001 & 0.0000 & 0.0006 & 0.0001 & 0.0000 & 0.0000 & 0.0000 & 0.0006 & 0.0000 & 0.0000 \\
\hline $\mathrm{Br}$ & 0.0000 & 0.0001 & 0.0006 & 0.0001 & -0.0001 & 0.0000 & 0.0001 & 0.0006 & 0.0001 & -0.0001 \\
\hline $\mathrm{Rb}$ & .0001 & 0.0000 & 0.0005 & 0.0000 & -0.0001 & 0.0000 & 0.0000 & 0.0005 & 0.0000 & -0.0001 \\
\hline $\mathrm{Sr}$ & 0.0001 & 0.0001 & 0.0006 & 0.0003 & 0.0001 & 0.0001 & 0.0001 & 0.0006 & 0.0002 & 0.0000 \\
\hline Y & -0.0001 & 0.0000 & 0.0007 & 0.0000 & -0.0001 & 0.0000 & 0.0001 & 0.0007 & 0.0000 & -0.0001 \\
\hline $\mathrm{Zr}$ & 0.0003 & 0.0002 & 0.0008 & 0.0005 & 0.0000 & 0.0003 & 0.0003 & 0.0008 & 0.0006 & 0.0000 \\
\hline Mo & 0.0002 & 0.0002 & 0.0015 & 0.0005 & 0.0000 & 0.0001 & 0.0002 & 0.0015 & 0.0006 & 0.0000 \\
\hline $\mathrm{Pd}$ & 0.0001 & 0.0002 & 0.0043 & 0.0004 & 0.0000 & 0.0002 & 0.0004 & 0.0042 & 0.0010 & 0.0000 \\
\hline $\mathrm{Ag}$ & -0.0006 & 0.0005 & 0.0050 & 0.0001 & -0.0012 & -0.0005 & 0.0006 & 0.0049 & 0.0000 & -0.0012 \\
\hline $\mathrm{Cd}$ & -0.0004 & 0.0005 & 0.0051 & 0.0004 & -0.0007 & -0.0003 & 0.0005 & 0.0050 & 0.0004 & -0.0007 \\
\hline In & -0.0007 & 0.0000 & 0.0063 & -0.0007 & -0.0007 & -0.0007 & 0.0000 & 0.0061 & -0.0007 & -0.0007 \\
\hline Sn & 0.0009 & 0.0007 & 0.0080 & 0.0018 & 0.0000 & 0.0006 & 0.0005 & 0.0079 & 0.0010 & 0.0000 \\
\hline $\mathrm{Sb}$ & 0.0008 & 0.0007 & 0.0093 & 0.0019 & 0.0001 & 0.0007 & 0.0007 & 0.0091 & 0.0016 & 0.0000 \\
\hline $\mathrm{Ba}$ & .0128 & 0.0007 & 0.0343 & -0.0115 & -0.0132 & -0.0089 & 0.0060 & 0.0336 & -0.0004 & -0.0132 \\
\hline $\mathrm{La}$ & -0.0045 & 0.0045 & 0.0455 & -0.0016 & -0.0123 & -0.0065 & 0.0063 & 0.0447 & 0.0032 & -0.0133 \\
\hline $\mathrm{Au}$ & .0001 & 0.0002 & 0.0017 & 0.0002 & -0.0002 & -0.0002 & 0.0000 & 0.0016 & -0.0002 & -0.0002 \\
\hline $\mathrm{Hg}$ & .0002 & 0.0000 & 0.0014 & -0.0002 & -0.0002 & -0.0002 & 0.0000 & 0.0013 & -0.0002 & -0.0002 \\
\hline $\mathrm{Ti}$ & -0.0002 & 0.0001 & 0.0013 & -0.0001 & -0.0002 & -0.0002 & 0.0000 & 0.0013 & -0.0001 & -0.0002 \\
\hline $\mathrm{Pb}$ & 0.0006 & 0.0002 & 0.0017 & 0.0009 & 0.0004 & 0.0001 & 0.0001 & 0.0016 & 0.0003 & 0.0000 \\
\hline $\mathrm{U}$ & 0.0000 & 0.0001 & 0.0013 & 0.0002 & 0.0000 & 0.0000 & 0.0001 & 0.0012 & 0.0002 & 0.0000 \\
\hline
\end{tabular}


Table 9. Statistics for CNG and RFG Dodge Caravans for US06 PM

Chemical Species Emission Rates (mg/mi)

\begin{tabular}{|c|c|c|c|c|c|c|c|c|c|c|}
\hline \multirow[b]{2}{*}{ Species } & \multicolumn{5}{|c|}{ CNG Dodge Caravans } & \multicolumn{5}{|c|}{ RFG Dodge Caravans } \\
\hline & Avg. & St. Dev. & $\begin{array}{l}\text { Avg. } \\
\text { Uncert. }\end{array}$ & Max. & Min. & Avg. & St. Dev. & $\begin{array}{l}\text { Avg. } \\
\text { Uncert. }\end{array}$ & Max. & Min. \\
\hline Organic Carbon & 4.2170 & 3.5173 & 0.4475 & 6.7041 & 1.7299 & 0.9517 & 0.4863 & 0.1429 & 1.2955 & 0.6078 \\
\hline Elemental Carbon & 1.3191 & 0.4662 & 0.1314 & 1.6487 & 0.9894 & 1.9788 & 2.3408 & 0.1972 & 3.6341 & 0.3236 \\
\hline Total Carbon & 5.5361 & 3.9834 & 0.5510 & 8.3528 & 2.7194 & 2.9305 & 2.8272 & 0.3155 & 4.9296 & 0.9314 \\
\hline $\mathrm{NO}_{3}^{-}$ & 0.0408 & 0.0120 & 0.0146 & 0.0493 & 0.0323 & 0.0697 & 0.1033 & 0.0255 & 0.1428 & -0.0033 \\
\hline $\mathrm{SO}_{4}{ }^{2-}$ & 0.0417 & 0.0038 & 0.0135 & 0.0444 & 0.0390 & 0.1552 & 0.1632 & 0.0282 & 0.2706 & 0.0397 \\
\hline $\mathrm{Cl}^{-}$ & -0.0017 & 0.0009 & 0.0124 & -0.0011 & -0.0023 & 0.0371 & 0.0328 & 0.0234 & 0.0603 & 0.0139 \\
\hline $\mathrm{NH}_{4}^{+}$ & 0.0501 & 0.0277 & 0.0135 & 0.0697 & 0.0305 & 0.0781 & 0.0786 & 0.0242 & 0.1337 & 0.0225 \\
\hline $\mathrm{Na}$ & -0.0063 & 0.0000 & 0.0284 & -0.0063 & -0.0063 & -0.0063 & 0.0000 & 0.0732 & -0.0063 & -0.0063 \\
\hline $\mathrm{Mg}$ & 0.0373 & 0.0022 & 0.0092 & 0.0389 & 0.0357 & 0.1115 & 0.0432 & 0.0160 & 0.1421 & 0.0810 \\
\hline $\mathrm{Al}$ & 0.0620 & 0.0297 & 0.0070 & 0.0830 & 0.0409 & 0.0350 & 0.0424 & 0.0073 & 0.0650 & 0.0050 \\
\hline $\mathrm{Si}$ & 0.3351 & 0.2194 & 0.0301 & 0.4903 & 0.1800 & 0.1373 & 0.1165 & 0.0131 & 0.2196 & 0.0549 \\
\hline $\mathrm{P}$ & 0.0206 & 0.0104 & 0.0022 & 0.0280 & 0.0132 & 0.1084 & 0.0474 & 0.0102 & 0.1419 & 0.0748 \\
\hline$S$ & 0.0607 & 0.0189 & 0.0055 & 0.0740 & 0.0474 & 0.1234 & 0.0890 & 0.0113 & 0.1863 & 0.0604 \\
\hline $\mathrm{Cl}$ & 0.0211 & 0.0088 & 0.0034 & 0.0273 & 0.0149 & 0.0508 & 0.0055 & 0.0060 & 0.0546 & 0.0469 \\
\hline $\mathrm{K}$ & 0.0194 & 0.0140 & 0.0028 & 0.0294 & 0.0095 & 0.0036 & 0.0046 & 0.0026 & 0.0069 & 0.0003 \\
\hline $\mathrm{Ca}$ & 0.0203 & 0.0076 & 0.0025 & 0.0257 & 0.0150 & 0.1005 & 0.0991 & 0.0095 & 0.1706 & 0.0305 \\
\hline $\mathrm{Ti}$ & 0.0045 & 0.0039 & 0.0118 & 0.0072 & 0.0017 & 0.0004 & 0.0006 & 0.0216 & 0.0008 & 0.0000 \\
\hline V & 0.0013 & 0.0013 & 0.0055 & 0.0023 & 0.0004 & 0.0002 & 0.0003 & 0.0091 & 0.0004 & 0.0000 \\
\hline $\mathrm{Cr}$ & 0.0082 & 0.0062 & 0.0018 & 0.0126 & 0.0038 & 0.0063 & 0.0062 & 0.0019 & 0.0107 & 0.0020 \\
\hline $\mathrm{Mn}$ & 0.0014 & 0.0008 & 0.0009 & 0.0020 & 0.0008 & 0.0025 & 0.0023 & 0.0012 & 0.0041 & 0.0009 \\
\hline $\mathrm{Fe}$ & 0.1559 & 0.0864 & 0.0140 & 0.2169 & 0.0948 & 0.3782 & 0.4323 & 0.0339 & 0.6838 & 0.0725 \\
\hline Co & 0.0000 & 0.0000 & 0.0026 & 0.0000 & 0.0000 & 0.0000 & 0.0000 & 0.0063 & 0.0000 & 0.0000 \\
\hline $\mathrm{Ni}$ & 0.0034 & 0.0008 & 0.0006 & 0.0040 & 0.0029 & 0.0063 & 0.0039 & 0.0009 & 0.0091 & 0.0036 \\
\hline $\mathrm{Cu}$ & 0.0019 & 0.0001 & 0.0006 & 0.0020 & 0.0018 & 0.0189 & 0.0004 & 0.0019 & 0.0192 & 0.0187 \\
\hline $\mathrm{Zn}$ & 0.0320 & 0.0162 & 0.0029 & 0.0434 & 0.0206 & 0.1602 & 0.0455 & 0.0144 & 0.1924 & 0.1281 \\
\hline $\mathrm{Ga}$ & -0.0002 & 0.0000 & 0.0010 & -0.0002 & -0.0002 & -0.0002 & 0.0000 & 0.0018 & -0.0002 & -0.0002 \\
\hline As & 0.0000 & 0.0000 & 0.0011 & 0.0000 & 0.0000 & 0.0000 & 0.0000 & 0.0024 & 0.0000 & 0.0000 \\
\hline $\mathrm{Se}$ & 0.0000 & 0.0000 & 0.0006 & 0.0000 & 0.0000 & 0.0000 & 0.0000 & 0.0010 & 0.0000 & 0.0000 \\
\hline $\mathrm{Br}$ & 0.0007 & 0.0000 & 0.0005 & 0.0008 & 0.0007 & 0.0018 & 0.0020 & 0.0007 & 0.0033 & 0.0004 \\
\hline $\mathrm{Rb}$ & 0.0001 & 0.0000 & 0.0005 & 0.0001 & 0.0001 & -0.0001 & 0.0000 & 0.0009 & -0.0001 & -0.0001 \\
\hline $\mathrm{Sr}$ & 0.0001 & 0.0001 & 0.0005 & 0.0002 & 0.0001 & 0.0001 & 0.0000 & 0.0010 & 0.0001 & 0.0001 \\
\hline Y & -0.0001 & 0.0000 & 0.0007 & -0.0001 & -0.0001 & 0.0001 & 0.0002 & 0.0012 & 0.0002 & -0.0001 \\
\hline $\mathrm{Zr}$ & 0.0020 & 0.0015 & 0.0008 & 0.0031 & 0.0010 & 0.0006 & 0.0006 & 0.0014 & 0.0011 & 0.0001 \\
\hline Mo & 0.0006 & 0.0003 & 0.0014 & 0.0008 & 0.0004 & 0.0011 & 0.0005 & 0.0025 & 0.0015 & 0.0008 \\
\hline $\mathrm{Pd}$ & 0.0017 & 0.0023 & 0.0040 & 0.0033 & 0.0000 & 0.0002 & 0.0003 & 0.0073 & 0.0005 & 0.0000 \\
\hline $\mathrm{Ag}$ & -0.0012 & 0.0000 & 0.0047 & -0.0012 & -0.0012 & 0.0007 & 0.0024 & 0.0085 & 0.0024 & -0.0009 \\
\hline $\mathrm{Cd}$ & -0.0007 & 0.0001 & 0.0048 & -0.0006 & -0.0007 & 0.0003 & 0.0002 & 0.0087 & 0.0004 & 0.0001 \\
\hline In & -0.0007 & 0.0000 & 0.0058 & -0.0007 & -0.0007 & 0.0006 & 0.0018 & 0.0104 & 0.0019 & -0.0007 \\
\hline Sn & 0.0007 & 0.0002 & 0.0075 & 0.0008 & 0.0005 & 0.0055 & 0.0071 & 0.0135 & 0.0105 & 0.0006 \\
\hline $\mathrm{Sb}$ & 0.0010 & 0.0006 & 0.0087 & 0.0014 & 0.0005 & 0.0040 & 0.0023 & 0.0151 & 0.0056 & 0.0024 \\
\hline $\mathrm{Ba}$ & -0.0078 & 0.0006 & 0.0320 & -0.0074 & -0.0082 & 0.0145 & 0.0391 & 0.0583 & 0.0422 & -0.0132 \\
\hline $\mathrm{La}$ & -0.0133 & 0.0000 & 0.0426 & -0.0133 & -0.0133 & -0.0133 & 0.0000 & 0.0760 & -0.0133 & -0.0133 \\
\hline $\mathrm{Au}$ & 0.0000 & 0.0000 & 0.0021 & 0.0000 & -0.0001 & 0.0002 & 0.0006 & 0.0067 & 0.0006 & -0.0002 \\
\hline $\mathrm{Hg}$ & -0.0002 & 0.0000 & 0.0013 & -0.0002 & -0.0002 & -0.0002 & 0.0000 & 0.0024 & -0.0002 & -0.0002 \\
\hline $\mathrm{Ti}$ & -0.0002 & 0.0000 & 0.0012 & -0.0002 & -0.0002 & -0.0002 & 0.0000 & 0.0022 & -0.0002 & -0.0002 \\
\hline $\mathrm{Pb}$ & 0.0006 & 0.0000 & 0.0015 & 0.0007 & 0.0006 & 0.0061 & 0.0061 & 0.0019 & 0.0105 & 0.0018 \\
\hline $\mathrm{U}$ & 0.0001 & 0.0000 & 0.0012 & 0.0001 & 0.0000 & 0.0000 & 0.0000 & 0.0021 & 0.0000 & 0.0000 \\
\hline
\end{tabular}


Table 10. Statistics for M85 and RFG Ford Taurus for US06 PM

Chemical Species Emission Rates (mg/mi)

\begin{tabular}{|c|c|c|c|c|c|c|c|c|c|c|}
\hline \multirow[b]{2}{*}{ Species } & \multicolumn{5}{|c|}{ M85 Ford Tauruses } & \multicolumn{5}{|c|}{ RFG Ford Tauruses } \\
\hline & Avg. & St. Dev. & $\begin{array}{l}\text { Avg. } \\
\text { Uncert. }\end{array}$ & Max. & Min. & Avg. & St. Dev. & $\begin{array}{l}\text { Avg. } \\
\text { Uncert. }\end{array}$ & Max. & Min. \\
\hline Organic Carbon & 0.3797 & 0.0207 & 0.1178 & 0.3944 & 0.3650 & 0.2515 & 0.1039 & 0.1077 & 0.3250 & 0.1781 \\
\hline Elemental Carbon & 4435 & 0.2839 & 0.0472 & 0.6442 & 0.2428 & 0.7554 & 0.3951 & 0.0728 & 1.0348 & 0.4760 \\
\hline Total Carbon & 8232 & 0.2631 & 0.1404 & 1.0093 & 0.6371 & 1.0069 & 0.2913 & 0.1491 & 1.2129 & 0.8009 \\
\hline $\mathrm{NO}_{3}^{-}$ & -0.0081 & 0.0038 & 0.0136 & -0.0054 & -0.0107 & -0.0151 & 0.0057 & 0.0136 & -0.0111 & -0.0191 \\
\hline $\mathrm{SO}_{4}{ }^{2-}$ & 0.0415 & 0.0546 & 0.0144 & 0.0802 & 0.0029 & 0.0035 & 0.0175 & 0.0130 & 0.0158 & -0.0089 \\
\hline $\mathrm{Cl}^{-}$ & 0852 & 0.0891 & 0.0182 & 0.1482 & 0.0223 & -0.0087 & 0.0027 & 0.0126 & -0.0068 & -0.0105 \\
\hline $\mathrm{NH}_{4}^{+}$ & 0814 & 0.0047 & 0.0202 & 0.0847 & 0.0781 & 0.0087 & 0.0100 & 0.0130 & 0.0158 & 0.0016 \\
\hline $\mathrm{Na}$ & .0044 & 0.0027 & 0.0284 & -0.0025 & -0.0063 & -0.0063 & 0.0000 & 0.0248 & -0.0063 & -0.0063 \\
\hline $\mathrm{Mg}$ & 0.0016 & 0.0090 & 0.0101 & 0.0080 & -0.0048 & 0.0008 & 0.0011 & 0.0097 & 0.0016 & 0.0000 \\
\hline $\mathrm{Al}$ & -0.0027 & 0.0015 & 0.0063 & -0.0017 & -0.0037 & -0.0025 & 0.0018 & 0.0054 & -0.0013 & -0.0037 \\
\hline $\mathrm{Si}$ & 0.5004 & 0.1144 & 0.0449 & 0.5812 & 0.4195 & 0.3646 & 0.1809 & 0.0327 & 0.4925 & 0.2368 \\
\hline $\mathrm{P}$ & 0105 & 0.0022 & 0.0016 & 0.0121 & 0.0089 & 0.0045 & 0.0027 & 0.0012 & 0.0064 & 0.0026 \\
\hline$S$ & 0387 & 0.0413 & 0.0037 & 0.0680 & 0.0095 & 0.0105 & 0.0023 & 0.0013 & 0.0122 & 0.0089 \\
\hline $\mathrm{Cl}$ & 1386 & 0.1031 & 0.0129 & 0.2114 & 0.0657 & 0.0049 & 0.0004 & 0.0027 & 0.0052 & 0.0046 \\
\hline K & 0.0000 & 0.0009 & 0.0022 & 0.0007 & -0.0007 & -0.0009 & 0.0003 & 0.0024 & -0.0007 & -0.0011 \\
\hline $\mathrm{Ca}$ & 0.0289 & 0.0071 & 0.0031 & 0.0339 & 0.0239 & 0.0198 & 0.0071 & 0.0024 & 0.0248 & 0.0148 \\
\hline $\mathrm{Ti}$ & 0.0000 & 0.0000 & 0.0124 & 0.0000 & 0.0000 & 0.0006 & 0.0008 & 0.0123 & 0.0012 & 0.0000 \\
\hline V & 0.0000 & 0.0000 & 0.0060 & 0.0000 & 0.0000 & 0.0000 & 0.0000 & 0.0059 & 0.0000 & 0.0000 \\
\hline $\mathrm{Cr}$ & 0.0001 & 0.0001 & 0.0018 & 0.0002 & 0.0000 & 0.0001 & 0.0002 & 0.0017 & 0.0002 & 0.0000 \\
\hline Mn & 0.0000 & 0.0000 & 0.0010 & 0.0000 & -0.0001 & -0.0001 & 0.0000 & 0.0010 & -0.0001 & -0.0001 \\
\hline $\mathrm{Fe}$ & 0290 & 0.0245 & 0.0027 & 0.0463 & 0.0116 & 0.0184 & 0.0182 & 0.0018 & 0.0313 & 0.0055 \\
\hline Co & 0001 & 0.0000 & 0.0008 & 0.0001 & 0.0001 & 0.0000 & 0.0000 & 0.0007 & 0.0000 & 0.0000 \\
\hline $\mathrm{Ni}$ & .0002 & 0.0002 & 0.0006 & 0.0004 & 0.0001 & 0.0001 & 0.0001 & 0.0006 & 0.0001 & 0.0000 \\
\hline $\mathrm{Cu}$ & 0021 & 0.0025 & 0.0006 & 0.0039 & 0.0003 & 0.0011 & 0.0011 & 0.0006 & 0.0018 & 0.0003 \\
\hline $\mathrm{Zn}$ & 0148 & 0.0032 & 0.0014 & 0.0170 & 0.0125 & 0.0065 & 0.0034 & 0.0008 & 0.0089 & 0.0040 \\
\hline $\mathrm{Ga}$ & .0001 & 0.0001 & 0.0010 & -0.0001 & -0.0002 & -0.0002 & 0.0000 & 0.0010 & -0.0002 & -0.0002 \\
\hline As & 0.0000 & 0.0000 & 0.0011 & 0.0000 & & 0.0000 & 0.0001 & 0.0011 & 0.0000 & 0.0000 \\
\hline $\mathrm{Se}$ & 0.0000 & 0.0000 & 0.0006 & 0.0000 & 0.0000 & 0.0000 & 0.0000 & 0.0006 & 0.0000 & 0.0000 \\
\hline $\mathrm{Br}$ & .0013 & 0.0004 & 0.0006 & 0.0016 & 0.0010 & 0.0002 & 0.0001 & 0.0005 & 0.0003 & 0.0001 \\
\hline $\mathrm{Rb}$ & .0001 & 0.0000 & 0.0005 & -0.0001 & -0.0001 & 0.0000 & 0.0000 & 0.0005 & 0.0000 & -0.0001 \\
\hline $\mathrm{Sr}$ & .0002 & 0.0002 & 0.0005 & 0.0003 & 0.0001 & 0.0002 & 0.0001 & 0.0005 & 0.0003 & 0.0001 \\
\hline Y & -0.0001 & 0.0000 & 0.0007 & -0.0001 & -0.0001 & -0.0001 & 0.0000 & 0.0007 & 0.0000 & -0.0001 \\
\hline $\mathrm{Zr}$ & 0.0002 & 0.0003 & 0.0008 & 0.0005 & 0.0000 & 0.0001 & 0.0002 & 0.0008 & 0.0003 & 0.0000 \\
\hline Mo & 0.0001 & 0.0001 & 0.0014 & 0.0001 & 0.0000 & 0.0001 & 0.0001 & 0.0014 & 0.0001 & 0.0000 \\
\hline $\mathrm{Pd}$ & 0.0001 & 0.0001 & 0.0041 & 0.0001 & 0.0000 & 0.0000 & 0.0000 & 0.0041 & 0.0000 & 0.0000 \\
\hline $\mathrm{Ag}$ & -0.0008 & 0.0001 & 0.0048 & -0.0007 & -0.0008 & -0.0011 & 0.0000 & 0.0047 & -0.0011 & -0.0011 \\
\hline $\mathrm{Cd}$ & -0.0003 & 0.0006 & 0.0049 & 0.0002 & -0.0007 & -0.0003 & 0.0006 & 0.0048 & 0.0001 & -0.0007 \\
\hline In & -0.0007 & 0.0000 & 0.0059 & -0.0007 & -0.0007 & -0.0002 & 0.0007 & 0.0059 & 0.0003 & -0.0007 \\
\hline Sn & 0.0020 & 0.0012 & 0.0074 & 0.0029 & 0.0011 & 0.0005 & 0.0007 & 0.0076 & 0.0010 & 0.0000 \\
\hline $\mathrm{Sb}$ & 0.0013 & 0.0004 & 0.0088 & 0.0016 & 0.0010 & 0.0004 & 0.0006 & 0.0088 & 0.0008 & 0.0000 \\
\hline $\mathrm{Ba}$ & .0008 & 0.0091 & 0.0315 & 0.0056 & -0.0073 & -0.0060 & 0.0102 & 0.0314 & 0.0013 & -0.0132 \\
\hline $\mathrm{La}$ & .0028 & 0.0008 & 0.0431 & -0.0023 & -0.0034 & -0.0038 & 0.0059 & 0.0429 & 0.0004 & -0.0080 \\
\hline $\mathrm{Au}$ & .0002 & 0.0000 & 0.0017 & -0.0002 & -0.0002 & -0.0002 & 0.0000 & 0.0016 & -0.0002 & -0.0002 \\
\hline $\mathrm{Hg}$ & .0002 & 0.0001 & 0.0013 & -0.0001 & -0.0002 & -0.0002 & 0.0001 & 0.0013 & -0.0001 & -0.0002 \\
\hline $\mathrm{Ti}$ & .0002 & 0.0000 & 0.0012 & -0.0002 & -0.0002 & -0.0002 & 0.0000 & 0.0012 & -0.0002 & -0.0002 \\
\hline $\mathrm{Pb}$ & .0008 & 0.0006 & 0.0016 & 0.0012 & 0.0004 & 0.0002 & 0.0002 & 0.0016 & 0.0003 & 0.0001 \\
\hline $\mathrm{U}$ & 0.0000 & 0.0000 & 0.0012 & 0.0000 & 0.0000 & 0.0000 & 0.0000 & 0.0012 & 0.0000 & 0.0000 \\
\hline
\end{tabular}


It should be noted that the low emissions levels and the large sample-to-sample variability (as indicated by the large standard deviations) make it difficult to differentiate between the species profiles for different vehicle/fuel combinations or to compare the US06 and FTP. It should also be noted that mass identified from the chemical analyses was generally less than that obtained from the gravimetric measurements, as shown in Appendices F and G. This could be because of to the higher blank levels for the chemical analysis and organic carbon measurements, the fact that not all species that contribute to the particle composition are measured, or the difficulties in determining total carbon based on TOR from a small section of the filter, as has been observed in previous studies (Sagebiel et al., 1997; Watson et al., 1994).

\subsection{PAH, Hopane, and Sterane Emission Results}

Total PAH emission rates were obtained for each fuel/vehicle group. The FTP PAH emission results are presented in Table 11 and Figure 11 for the CNG and RFG Dodge Caravans and in Table 12 and Figure 12 for the M85 and RFG Ford Tauruses. These results were obtained by grouping samples for all five vehicles in each vehicle/fuel group into a single sample for extraction and subsequent analysis. The US06 emission results for PAHs are presented in Table 13 and Figure 13 for the CNG and RFG Dodge Caravans and in Table 14 and Figure 14 for the M85 and RFG Ford Tauruses. These results were obtained by grouping samples from two of the vehicles in each group into a single sample for extraction and subsequent analysis. The emission rates are corrected for the contribution of trace species detected in the dilution tunnel, and as a result, include some negative values. For Tables 11-14, chemical components whose concentrations are at least twice the average uncertainty are shown in bold.

PAH emissions were highest for the RFG fueled vehicles. Total FTP PAH emissions rates were 1,142.0 $\mu \mathrm{g} / \mathrm{mi}$ for the RFG Dodge Caravans and $352.5 \mu \mathrm{g} / \mathrm{mi}$ for the RFG Ford Tauruses. Total PAH emissions were lower over the US06 with an emission rate of $965.1 \mu \mathrm{g} / \mathrm{mi}$ for the RFG Dodge Caravans and $203.1 \mu \mathrm{g} / \mathrm{mi}$ for the RFG Ford Tauruses. These levels are comparable to those reported by Siegel et al. (1994) for a normal-emitting vehicle, but are slightly less that those reported by Sagebiel et al. (1997) for high-emitting gasoline vehicles in Nevada. These levels are also slightly higher than those measured by Whitney (1997), since emission rates of semi-volative PAHs such as naphthalenes, methylnapthalenes and dimethylnaphthalenes were not quantified in that study. The distribution of PAHs for the gasoline vehicles is similar to that reported previously (Siegel et al., 1994; Sagebiel et al., 1997) with naphthalene, 2-methylnaphthalene, 1-methylnaphthalene, and dimethylnaphthalenes being the primary constituents.

Total PAH emission rates for the M85 Ford Tauruses were lower for the FTP $(160.6 \mu \mathrm{g} / \mathrm{mi})$ and considerably lower for the US06 $(21.7 \mu \mathrm{g} / \mathrm{mi})$ compared with the RFG Ford Tauruses. Naphthalene and methylnaphthalenes were the most prominent PAHs for the M85 vehicles. Other PAHs detected at levels below $10 \mu \mathrm{g} / \mathrm{mi}$ include biphenyl, phenanthrene, $\mathrm{C}$-methylfluorene, anathracene and pyrene. Total FTP PAH emissions for the CNG vehicles were considerably lower $(50.5 \mu \mathrm{g} / \mathrm{mi})$ than those for either the RFG or M85 vehicles. For the US06, total PAH emissions for the CNG vehicles $(31.6 \mu \mathrm{g} / \mathrm{mi})$ were lower than those for the RFG vehicles but comparable to those for the M85 vehicles. Unlike the RFG and M85 vehicles, naphthalenes, 2- 
methylnaphthalene, and 1-methylnaphthalene were not detected for the CNG vehicles. The only PAHs detected at levels greater than $3 \mu \mathrm{g} / \mathrm{mi}$ for CNG on both the FTP and US06 cycles were pyrene, fluoranthene, phenanthrene, and C-methylfluorene.

Analyses were also conducted for hopane and sterane emissions using the same sample groupings used for the PAH analyses. No hopane or sterane compounds were measured above detectable levels, however, for any of the vehicle/fuel/driving-cycle groups. Because hopanes and steranes are primarily oil tracers, this indicates that none of the test vehicles were excessive oil burners. It should be noted, however, that some elements that can be attributed to oil sources were identified in the XRF analysis (Mg, P, Ca, and Zn). 
Figure 11. PAH Mass Emission Rates for CNG/RFG Dodge Caravans for FTP

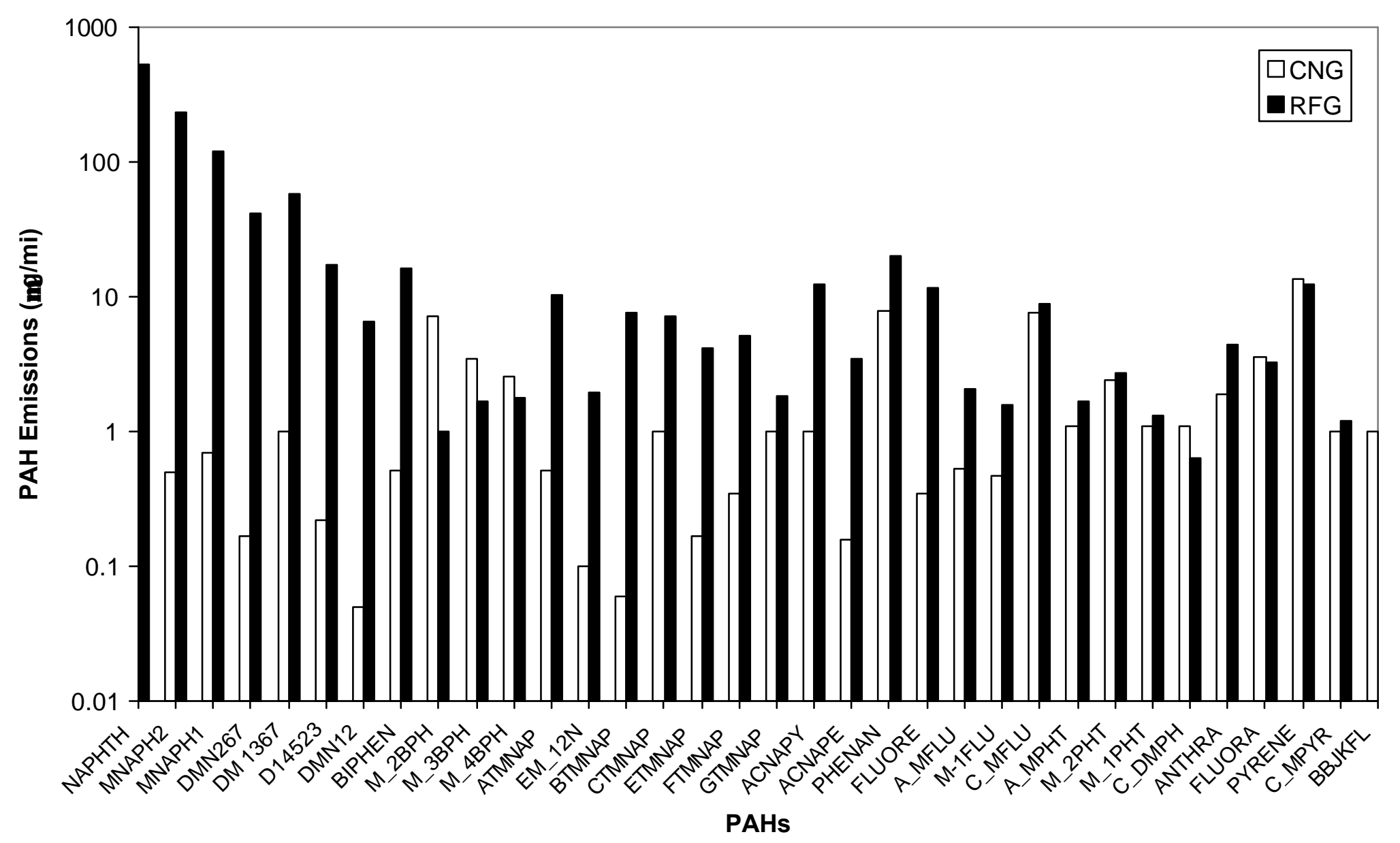


Figure 12. PAH Mass Emission Rates for M85/RFG Ford Tauruses for FTP

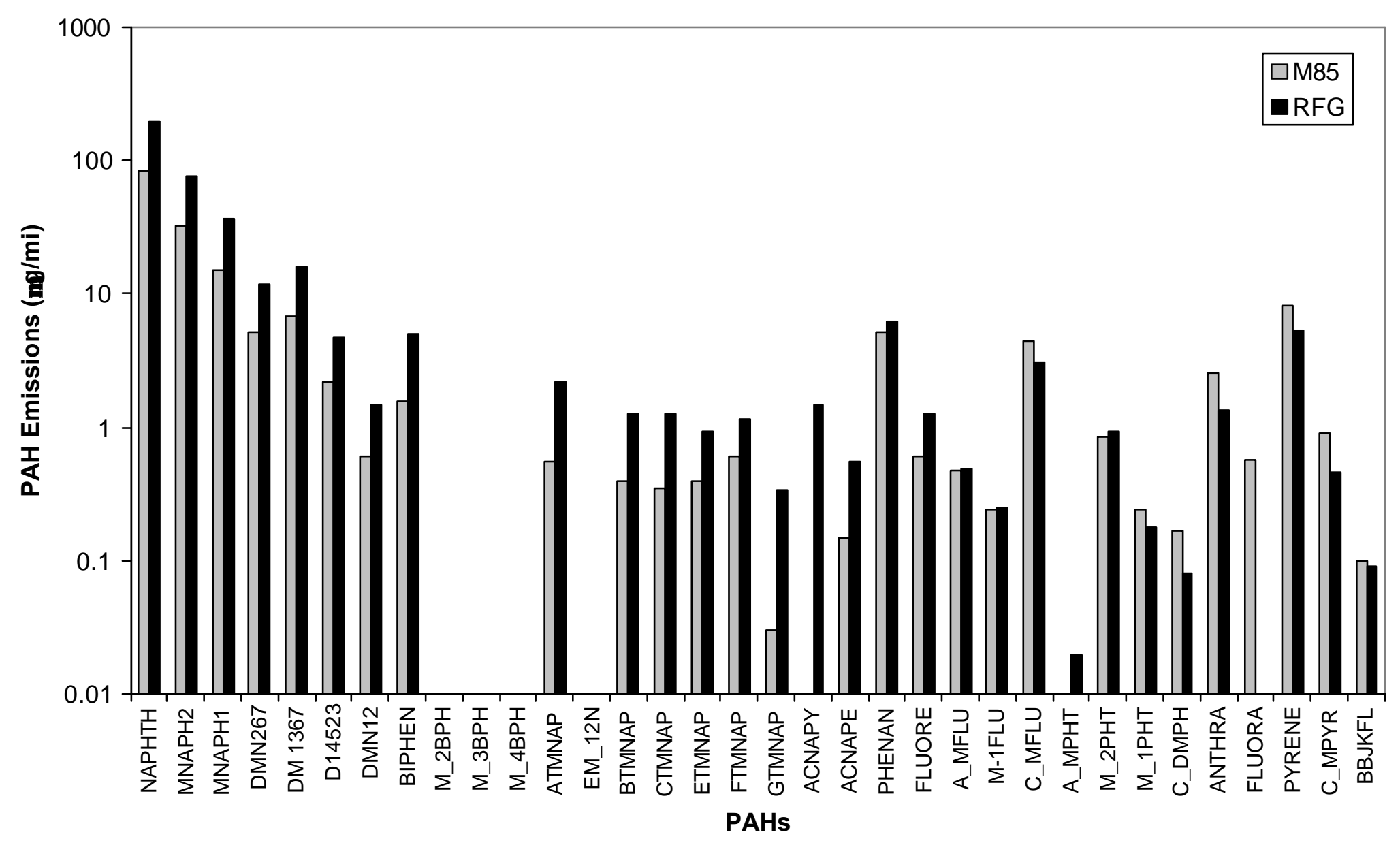


Figure 13. PAH Mass Emission Rates for CNG/RFG Dodge Caravans for US06

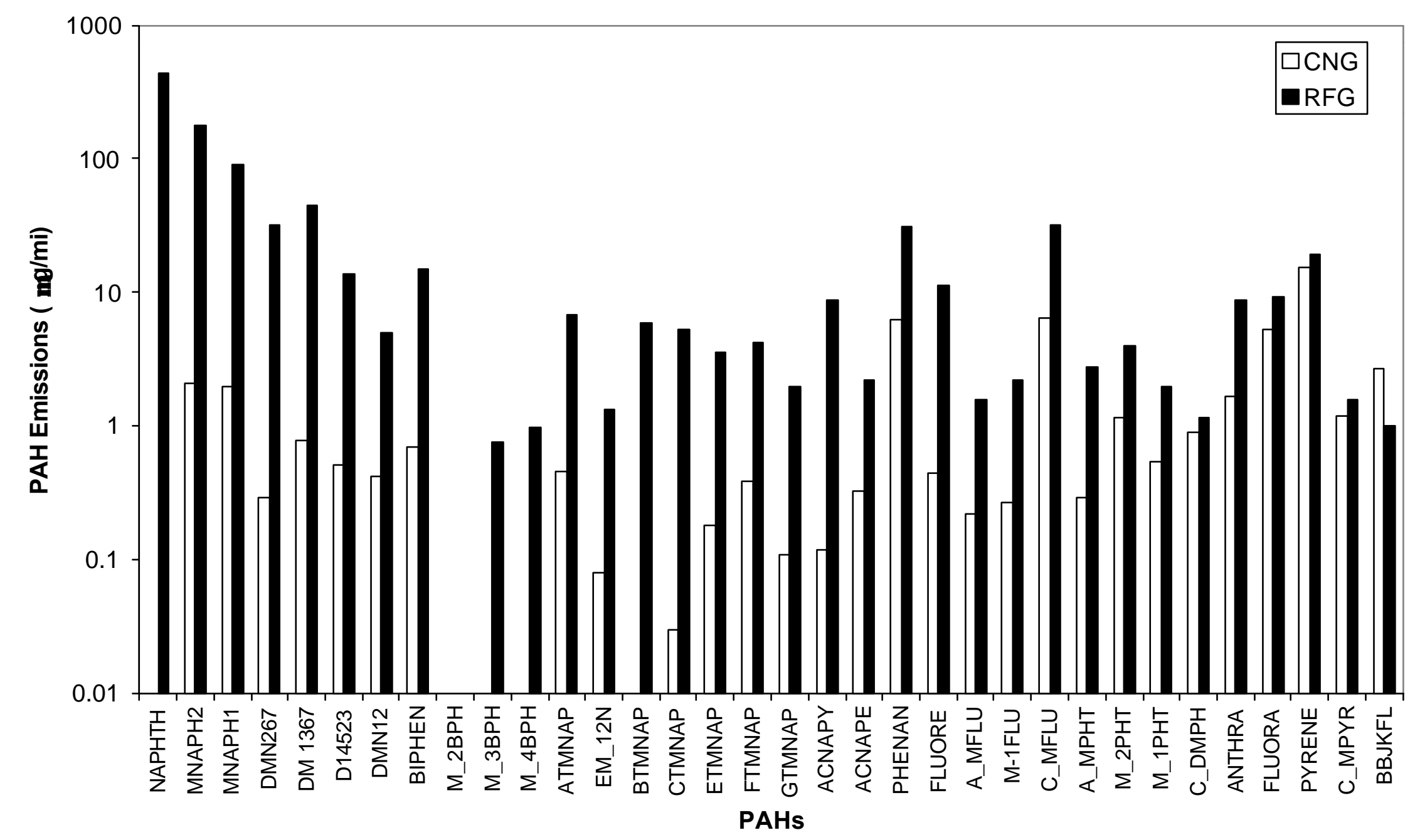


Figure 14. PAH Mass Emission Rates for M85/RFG Ford Tauruses for US06

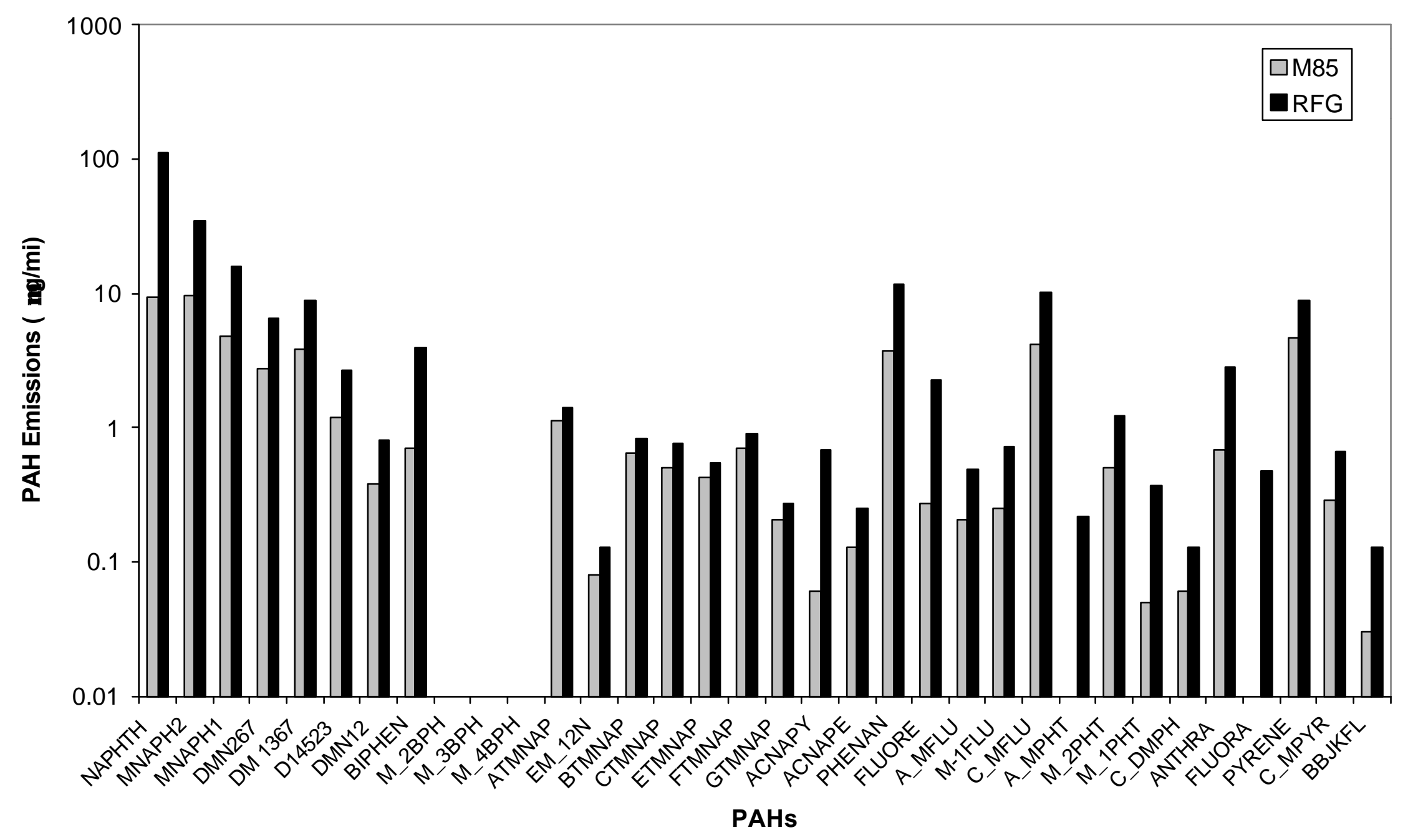


Table 11. Statistics for CNG and RFG Dodge Caravans for FTP PAH Emissions ( $\mu \mathrm{g} / \mathrm{mi})$

\begin{tabular}{|c|c|c|c|c|c|c|}
\hline \multirow[b]{2}{*}{ Naphthalene } & \multicolumn{3}{|c|}{ CNG Dodge Caravans } & \multicolumn{3}{|c|}{ RFG Dodge Caravans } \\
\hline & -2.51 & $+/-$ & 2.02 & 531.99 & $+/-$ & 55.89 \\
\hline 2-Methylnaphthalene & 0.51 & $+/-$ & 1.99 & 232.29 & $+/-$ & 24.52 \\
\hline 1-Methylnaphthalene & 0.71 & $+/-$ & 1.07 & 120.31 & $+/-$ & 12.77 \\
\hline 2,6+2,7-Dimethylnaphthalene & 0.17 & $+/-$ & 2.70 & 41.46 & $+/-$ & 5.17 \\
\hline $1,7+1,3+1,6$ & -0.31 & $+/-$ & 3.59 & 57.55 & $+/-$ & 7.03 \\
\hline Dimethylnaphthalene & & & & & & \\
\hline $2,3+1,4+1,5$ & 0.22 & $+/-$ & 5.12 & 17.51 & $+/-$ & 5.42 \\
\hline Dimethylnaphthalene & & & & & & \\
\hline 1,2-Dimethylnaphthalene & 0.05 & $+/-$ & 3.14 & 6.56 & $+/-$ & 3.22 \\
\hline 1,8-Dimethylnaphthalene & 0.00 & $+/-$ & 2.59 & 0.09 & $+/-$ & 2.58 \\
\hline Biphenyl & 0.52 & $+/-$ & 0.62 & 16.33 & $+/-$ & 1.85 \\
\hline 2-Methylbiphenyl & 7.23 & $+/-$ & 1.82 & -13.65 & $+/-$ & 1.67 \\
\hline 3-Methylbiphenyl & 3.54 & $+/-$ & 0.84 & 1.67 & $+/-$ & 0.73 \\
\hline 4-Methylbiphenyl & 2.55 & $+/-$ & 0.68 & 1.80 & $+/-$ & 0.62 \\
\hline A-Trimethylnaphthalene & 0.52 & $+/-$ & 0.48 & 10.40 & $+/-$ & 1.23 \\
\hline 1-Ethyl-2-methylnaphthalene & 0.10 & $+/-$ & 0.48 & 1.97 & $+/-$ & 0.54 \\
\hline B-Trimethylnaphthalene & 0.06 & $+/-$ & 0.48 & 7.79 & $+/-$ & 1.04 \\
\hline C-Trimethylnaphthalene & -0.03 & $+/-$ & 0.48 & 7.15 & $+/-$ & 0.95 \\
\hline 2-Ethyl-1-methylnaphthalene & -0.03 & $+/-$ & 0.48 & 0.19 & $+/-$ & 0.48 \\
\hline E-Trimethylnaphthalene & 0.17 & $+/-$ & 0.49 & 4.22 & $+/-$ & 0.78 \\
\hline F-Trimethylnaphthalene & 0.35 & $+/-$ & 0.48 & 5.15 & $+/-$ & 0.76 \\
\hline G-Trimethylnaphthalene & -0.06 & $+/-$ & 0.49 & 1.88 & $+/-$ & 0.68 \\
\hline H-Trimethylnaphthalene & -0.11 & $+1-$ & 0.48 & 0.39 & $+/-$ & 0.48 \\
\hline $1,2,8$-Trimethylnaphthalene & 0.02 & $+/-$ & 0.48 & 0.35 & $+/-$ & 0.52 \\
\hline Acenaphthylene & -0.15 & $+/-$ & 3.11 & 12.64 & $+/-$ & 3.44 \\
\hline Acenaphthene & 0.16 & $+/-$ & 1.40 & 3.47 & $+/-$ & 1.45 \\
\hline Phenanthrene & 7.87 & $+/-$ & 1.13 & 20.26 & $+/-$ & 2.32 \\
\hline Fluorene & 0.35 & $+/-$ & 0.56 & 11.61 & $+/-$ & 1.43 \\
\hline A-Methylfluorene & 0.53 & $+/-$ & 0.50 & 2.07 & $+/-$ & 0.59 \\
\hline 1-Methylfluorene & 0.47 & $+/-$ & 0.49 & 1.60 & $+/-$ & 0.54 \\
\hline B-Methylfluorene & -1.96 & $+/-$ & 0.57 & -1.53 & $+/-$ & 0.56 \\
\hline C-Methylfluorene & 7.77 & $+/-$ & 1.20 & 9.05 & $+/-$ & 1.35 \\
\hline A-Methylphenanthrene & 1.12 & $+/-$ & 0.57 & 1.70 & $+/-$ & 0.63 \\
\hline 2-Methylphenanthrene & 2.43 & $+/-$ & 0.56 & 2.75 & $+/-$ & 0.58 \\
\hline B-Methylphenanthrene & -0.31 & $+/-$ & 0.48 & -0.20 & $+/-$ & 0.48 \\
\hline C-Methylphenanthrene & 0.57 & $+/-$ & 0.53 & 0.43 & $+/-$ & 0.52 \\
\hline 1-Methylphenanthrene & 1.12 & $+/-$ & 0.51 & 1.31 & $+/-$ & 0.51 \\
\hline 3,6-Dimethylphenanthrene & 0.24 & $+/-$ & 0.49 & 0.31 & $+/-$ & 0.49 \\
\hline A-Dimethylphenanthrene & 0.65 & $+/-$ & 0.49 & 0.66 & $+/-$ & 0.49 \\
\hline B-Dimethylphenanthrene & 0.05 & $+/-$ & 0.48 & -0.10 & $+/-$ & 0.48 \\
\hline C-Dimethylphenanthrene & 1.11 & $+/-$ & 0.52 & 0.64 & $+/-$ & 0.49 \\
\hline 1,7-Dimethylphenanthrene & 0.40 & $+/-$ & 0.48 & 0.37 & $+/-$ & 0.48 \\
\hline D-Dimethylphenanthrene & 0.27 & $+/-$ & 0.48 & 0.14 & $+/-$ & 0.48 \\
\hline E-Dimethylphenanthrene & -0.31 & $+/-$ & 0.35 & -0.34 & $+/-$ & 0.34 \\
\hline Anthracene & 1.93 & $+/-$ & 0.57 & 4.49 & $+/-$ & 0.83 \\
\hline 9-Methylanthracene & -5.63 & $+/-$ & 1.10 & -5.55 & $+/-$ & 1.10 \\
\hline Fluoranthene & 3.57 & $+/-$ & 1.00 & 3.34 & $+/-$ & 0.98 \\
\hline Pyrene & 13.62 & $+/-$ & 1.54 & 12.60 & $+/-$ & 1.44 \\
\hline A-Methylpyrene & -0.24 & $+/-$ & 0.48 & -0.18 & $+/-$ & 0.48 \\
\hline B-Methylpyrene & 0.03 & $+/-$ & 0.48 & 0.04 & $+/-$ & 0.48 \\
\hline C-Methylpyrene & 1.00 & $+/-$ & 0.49 & 1.22 & $+/-$ & 0.50 \\
\hline D-Methylpyrene & 0.17 & $+/-$ & 0.48 & 0.45 & $+/-$ & 0.48 \\
\hline E-Methylpyrene & 0.39 & $+/-$ & 0.48 & 0.34 & $+/-$ & 0.48 \\
\hline F-Methylpyrene & 0.27 & $+/-$ & 0.68 & 0.30 & $+/-$ & 0.68 \\
\hline Retene & 0.00 & $+/-$ & 0.95 & -0.01 & $+/-$ & 0.95 \\
\hline Benzonaphthothiophene & -0.01 & $+/-$ & 1.40 & 0.00 & $+/-$ & 1.39 \\
\hline Benz(a)anthracene & 0.10 & $+/-$ & 0.50 & 0.44 & $+/-$ & 0.49 \\
\hline 7-Methylbenz[a]anthracene & -0.14 & $+/-$ & 0.71 & -0.15 & $+/-$ & 0.71 \\
\hline Chrysene & 0.08 & $+/-$ & 0.79 & 0.49 & $+/-$ & 0.79 \\
\hline Benzo $(b+j+k)$ fluoranthene & -0.01 & $+/-$ & 0.48 & 1.54 & $+/-$ & 0.55 \\
\hline Benzo(e)pyrene & 0.00 & $+/-$ & 1.53 & 0.42 & $+/-$ & 1.53 \\
\hline Benzo(a)pyrene & -0.02 & $+/-$ & 0.50 & 0.55 & $+/-$ & 0.49 \\
\hline 7-Methylbenzo[a]pyrene & -0.11 & $+/-$ & 1.29 & -0.10 & $+/-$ & 1.29 \\
\hline Indeno[1,2,3-cd]pyrene & -0.01 & $+/-$ & 1.87 & 0.41 & $+/-$ & 1.87 \\
\hline Dibenz $(a h+a c)$ anthracene & -0.03 & $+/-$ & 0.97 & -0.02 & $+/-$ & 0.96 \\
\hline Benzo(b)chrysene & -0.09 & $+/-$ & 1.67 & -0.07 & $+/-$ & 1.66 \\
\hline Benzo(ghi)perylene & -0.45 & $+/-$ & 0.54 & 0.53 & $+/-$ & 0.54 \\
\hline Coronene & 0.02 & $+/-$ & 0.05 & 0.68 & $+/-$ & 0.17 \\
\hline Total & 50.50 & & & 1142.00 & & \\
\hline
\end{tabular}


Table 12. Statistics for M85 and RFG FFV Ford Taurus for FTP PAH Emissions ( $\mu \mathrm{g} / \mathrm{mi})$

\begin{tabular}{|c|c|c|c|c|c|c|}
\hline & M85 & rd 7 & Irus & $\mathrm{RFG}$ & ord & urus \\
\hline Naphthalene & 84.38 & $+/-$ & 9.38 & 195.27 & $+1-$ & 20.80 \\
\hline 2-Methylnaphthalene & 32.61 & $+1-$ & 4.01 & 75.54 & $+/-$ & 8.23 \\
\hline 1-Methylnaphthalene & 15.25 & $+1-$ & 1.95 & 37.21 & $+/-$ & 4.10 \\
\hline 2,6+2,7-Dimethylnaphthalene & 5.14 & $+1-$ & 2.76 & 11.86 & $+/-$ & 2.98 \\
\hline $1,7+1,3+1,6$ & 6.77 & $+1-$ & 3.66 & 16.05 & $+1-$ & 3.97 \\
\hline Dimethylnaphthalene & & & & & & \\
\hline $2,3+1,4+1,5$ & 2.23 & $+/-$ & 5.12 & 4.68 & $+/-$ & 5.12 \\
\hline Dimethylnaphthalene & & & & & & \\
\hline 1,2-Dimethylnaphthalene & 0.61 & $+1-$ & 3.14 & 1.49 & $+/-$ & 3.13 \\
\hline 1,8-Dimethylnaphthalene & 0.00 & $+1-$ & 2.59 & 1.32 & $+1-$ & 2.67 \\
\hline Biphenyl & 1.59 & $+/-$ & 0.64 & 4.95 & $+1-$ & 0.82 \\
\hline 2-Methylbiphenyl & -5.31 & $+1-$ & 1.33 & -9.96 & $+1-$ & 1.45 \\
\hline 3-Methylbiphenyl & -1.07 & $+/-$ & 0.66 & -2.09 & $+1-$ & 0.65 \\
\hline 4-Methylbiphenyl & -0.42 & $+/-$ & 0.55 & -0.64 & $+/-$ & 0.54 \\
\hline A-Trimethylnaphthalene & 0.56 & $+/-$ & 0.48 & 2.17 & $+/-$ & 0.53 \\
\hline 1-Ethyl-2-methylnaphthalene & -0.03 & $+/-$ & 0.48 & 0.28 & $+/-$ & 0.48 \\
\hline B-Trimethylnaphthalene & 0.39 & $+/-$ & 0.49 & 1.25 & $+/-$ & 0.51 \\
\hline C-Trimethylnaphthalene & 0.35 & $+/-$ & 0.48 & 1.27 & $+/-$ & 0.51 \\
\hline 2-Ethyl-1-methylnaphthalene & 0.07 & $+/-$ & 0.48 & 0.08 & $+/-$ & 0.48 \\
\hline E-Trimethylnaphthalene & 0.40 & $+/-$ & 0.49 & 0.92 & $+/-$ & 0.50 \\
\hline F-Trimethylnaphthalene & 0.61 & $+/-$ & 0.48 & 1.17 & $+/-$ & 0.50 \\
\hline G-Trimethylnaphthalene & 0.03 & $+/-$ & 0.48 & 0.34 & $+/-$ & 0.49 \\
\hline H-Trimethylnaphthalene & -0.09 & $+/-$ & 0.48 & -0.09 & $+/-$ & 0.48 \\
\hline $1,2,8$-Trimethylnaphthalene & -0.07 & $+1-$ & 0.48 & 0.00 & $+1-$ & 0.48 \\
\hline Acenaphthylene & -0.18 & $+1-$ & 3.10 & 1.48 & $+1-$ & 3.10 \\
\hline Acenaphthene & 0.15 & $+/-$ & 1.40 & 0.55 & $+1-$ & 1.40 \\
\hline Phenanthrene & 5.22 & $+1-$ & 0.93 & 6.13 & $+/-$ & 0.99 \\
\hline Fluorene & 0.61 & $+/-$ & 0.56 & 1.28 & $+/-$ & 0.58 \\
\hline A-Methylfluorene & 0.47 & $+/-$ & 0.49 & 0.49 & $+/-$ & 0.49 \\
\hline 1-Methylfluorene & 0.24 & $+1-$ & 0.48 & 0.25 & $+/-$ & 0.48 \\
\hline B-Methylfluorene & -2.01 & $+/-$ & 0.57 & -1.99 & $+1-$ & 0.57 \\
\hline C-Methylfluorene & 4.38 & $+1-$ & 0.81 & 3.09 & $+1-$ & 0.67 \\
\hline A-Methylphenanthrene & -0.13 & $+/-$ & 0.49 & 0.02 & $+/-$ & 0.50 \\
\hline 2-Methylphenanthrene & 0.86 & $+/-$ & 0.49 & 0.94 & $+1-$ & 0.49 \\
\hline B-Methylphenanthrene & -0.36 & $+/-$ & 0.48 & -0.36 & $+1-$ & 0.48 \\
\hline C-Methylphenanthrene & -0.17 & $+/-$ & 0.49 & -0.25 & $+1-$ & 0.48 \\
\hline 1-Methylphenanthrene & 0.24 & $+/-$ & 0.48 & 0.18 & $+1-$ & 0.48 \\
\hline 3,6-Dimethylphenanthrene & -0.10 & $+/-$ & 0.48 & -0.10 & $+1-$ & 0.48 \\
\hline A-Dimethylphenanthrene & 0.18 & $+/-$ & 0.48 & 0.15 & $+/-$ & 0.48 \\
\hline B-Dimethylphenanthrene & -0.21 & $+/-$ & 0.48 & 0.28 & $+/-$ & 0.48 \\
\hline C-Dimethylphenanthrene & 0.17 & $+/-$ & 0.48 & 0.08 & $+/-$ & 0.48 \\
\hline 1,7-Dimethylphenanthrene & 0.04 & $+/-$ & 0.48 & -0.04 & $+1-$ & 0.48 \\
\hline D-Dimethylphenanthrene & 0.02 & $+/-$ & 0.48 & -0.04 & $+/-$ & 0.48 \\
\hline E-Dimethylphenanthrene & -0.57 & $+/-$ & 0.35 & -0.60 & $+1-$ & 0.34 \\
\hline Anthracene & 2.53 & $+/-$ & 0.61 & 1.35 & $+1-$ & 0.52 \\
\hline 9-Methylanthracene & -5.00 & $+1-$ & 1.09 & -5.61 & $+1-$ & 1.10 \\
\hline Fluoranthene & 0.57 & $+1-$ & 0.82 & -3.05 & $+1-$ & 0.76 \\
\hline Pyrene & 8.10 & $+/-$ & 1.02 & 5.33 & $+/-$ & 0.78 \\
\hline A-Methylpyrene & -0.08 & $+1-$ & 0.48 & -0.21 & $+1-$ & 0.48 \\
\hline B-Methylpyrene & 0.00 & $+/-$ & 0.48 & -0.22 & $+/-$ & 0.48 \\
\hline C-Methylpyrene & 0.90 & $+1-$ & 0.49 & 0.46 & $+/-$ & 0.48 \\
\hline D-Methylpyrene & 0.12 & $+1-$ & 0.48 & 0.03 & $+/-$ & 0.48 \\
\hline E-Methylpyrene & 0.06 & $+1-$ & 0.48 & 0.09 & $+1-$ & 0.48 \\
\hline F-Methylpyrene & 0.08 & $+/-$ & 0.68 & 0.06 & $+/-$ & 0.68 \\
\hline Retene & 0.02 & $+/-$ & 0.95 & -0.01 & $+1-$ & 0.95 \\
\hline Benzonaphthothiophene & 0.05 & $+/-$ & 1.40 & -0.01 & $+/-$ & 1.39 \\
\hline Benz(a)anthracene & 0.41 & $+/-$ & 0.51 & 0.15 & $+/-$ & 0.48 \\
\hline 7-Methylbenz[a]anthracene & 0.03 & $+/-$ & 0.72 & -0.16 & $+/-$ & 0.71 \\
\hline Chrysene & 0.21 & $+/-$ & 0.79 & 0.05 & $+/-$ & 0.78 \\
\hline Benzo $(b+j+k)$ fluoranthene & 0.10 & $+1-$ & 0.48 & 0.09 & $+1-$ & 0.48 \\
\hline Benzo(e)pyrene & 0.03 & $+/-$ & 1.53 & 0.01 & $+1-$ & 1.53 \\
\hline Benzo(a)pyrene & 0.19 & $+/-$ & 0.50 & 0.16 & $+/-$ & 0.48 \\
\hline 7-Methylbenzo[a]pyrene & -0.11 & $+/-$ & 1.29 & -0.11 & $+/-$ & 1.29 \\
\hline Indeno[ $[1,2,3$-cd]pyrene & 0.01 & $+/-$ & 1.87 & 0.00 & $+1-$ & 1.87 \\
\hline Dibenz $(a h+a c)$ anthracene & -0.03 & $+/-$ & 0.97 & -0.03 & $+/-$ & 0.95 \\
\hline Benzo(b)chrysene & -0.10 & $+1-$ & 1.67 & -0.10 & $+/-$ & 1.66 \\
\hline Benzo(ghi)perylene & -0.40 & $+1-$ & 0.54 & -0.40 & $+/-$ & 0.52 \\
\hline Coronene & 0.07 & $+1-$ & 0.05 & 0.04 & $+/-$ & 0.02 \\
\hline Total & 160.58 & & & 352.52 & & \\
\hline
\end{tabular}


Table 13. Statistics for CNG and RFG Dodge Caravans for USO6 PAH Emissions ( $\mu \mathrm{g} / \mathrm{mi})$

\begin{tabular}{|c|c|c|c|c|c|c|}
\hline \multirow[b]{2}{*}{ Naphthalene } & \multicolumn{3}{|c|}{ CNG Dodge Caravans } & \multicolumn{3}{|c|}{ RFG Dodge Caravans } \\
\hline & -4.27 & $+/-$ & 1.94 & 431.97 & $+/-$ & 45.47 \\
\hline 2-Methylnaphthalene & 2.10 & $+/-$ & 2.02 & 177.02 & $+/-$ & 18.75 \\
\hline 1-Methylnaphthalene & 2.00 & $+1-$ & 1.10 & 89.26 & $+1-$ & 9.51 \\
\hline 2,6+2,7-Dimethylnaphthalene & 0.29 & $+1-$ & 2.72 & 31.63 & $+1-$ & 4.32 \\
\hline $1,7+1,3+1,6$ & 0.77 & $+1-$ & 3.62 & 44.49 & $+/-$ & 5.91 \\
\hline Dimethylnaphthalene & & & & & & \\
\hline $2,3+1,4+1,5$ & 0.51 & $+/-$ & 5.17 & 13.84 & $+/-$ & 5.33 \\
\hline Dimethylnaphthalene & & & & & & \\
\hline 1,2-Dimethylnaphthalene & 0.42 & $+/-$ & 3.17 & 5.07 & $+/-$ & 3.20 \\
\hline 1,8-Dimethylnaphthalene & 0.04 & $+1-$ & 2.62 & 0.46 & $+1-$ & 2.61 \\
\hline Biphenyl & 0.69 & $+/-$ & 0.63 & 15.08 & $+/-$ & 1.73 \\
\hline 2-Methylbiphenyl & -9.57 & $+1-$ & 1.45 & -13.65 & $+1-$ & 1.67 \\
\hline 3-Methylbiphenyl & -2.55 & $+/-$ & 0.67 & 0.76 & $+/-$ & 0.69 \\
\hline 4-Methylbiphenyl & -0.75 & $+/-$ & 0.55 & 0.98 & $+/-$ & 0.58 \\
\hline A-Trimethylnaphthalene & 0.46 & $+/-$ & 0.49 & 6.90 & $+/-$ & 0.89 \\
\hline 1-Ethyl-2-methylnaphthalene & 0.08 & $+/-$ & 0.48 & 1.33 & $+/-$ & 0.51 \\
\hline B-Trimethylnaphthalene & -0.04 & $+/-$ & 0.49 & 5.87 & $+/-$ & 0.85 \\
\hline C-Trimethylnaphthalene & 0.03 & $+/-$ & 0.49 & 5.35 & $+/-$ & 0.78 \\
\hline 2-Ethyl-1-methylnaphthalene & 0.01 & $+/-$ & 0.48 & 0.12 & $+/-$ & 0.48 \\
\hline E-Trimethylnaphthalene & 0.18 & $+/-$ & 0.49 & 3.59 & $+/-$ & 0.71 \\
\hline F-Trimethylnaphthalene & 0.39 & $+/-$ & 0.49 & 4.27 & $+/-$ & 0.69 \\
\hline G-Trimethylnaphthalene & 0.11 & $+/-$ & 0.49 & 1.96 & $+/-$ & 0.70 \\
\hline H-Trimethylnaphthalene & -0.06 & $+1-$ & 0.48 & 0.31 & $+1-$ & 0.48 \\
\hline 1,2,8-Trimethylnaphthalene & 0.01 & $+/-$ & 0.49 & 0.34 & $+/-$ & 0.52 \\
\hline Acenaphthylene & 0.12 & $+/-$ & 3.14 & 8.68 & $+/-$ & 3.27 \\
\hline Acenaphthene & 0.33 & $+/-$ & 1.41 & 2.24 & $+/-$ & 1.43 \\
\hline Phenanthrene & 6.24 & $+/-$ & 1.00 & 31.11 & $+/-$ & 3.45 \\
\hline Fluorene & 0.45 & $+/-$ & 0.57 & 11.18 & $+/-$ & 1.38 \\
\hline A-Methylfluorene & 0.22 & $+/-$ & 0.49 & 1.59 & $+/-$ & 0.55 \\
\hline 1-Methylfluorene & 0.27 & $+/-$ & 0.49 & 2.20 & $+/-$ & 0.60 \\
\hline B-Methylfluorene & -2.02 & $+/-$ & 0.57 & -1.51 & $+/-$ & 0.56 \\
\hline C-Methylfluorene & 6.42 & $+1-$ & 1.03 & 31.65 & $+1-$ & 4.24 \\
\hline A-Methylphenanthrene & 0.29 & $+/-$ & 0.51 & 2.74 & $+/-$ & 0.75 \\
\hline 2-Methylphenanthrene & 1.15 & $+/-$ & 0.50 & 4.03 & $+/-$ & 0.68 \\
\hline B-Methylphenanthrene & -0.36 & $+/-$ & 0.48 & -0.35 & $+/-$ & 0.48 \\
\hline C-Methylphenanthrene & 0.15 & $+/-$ & 0.50 & 0.94 & $+/-$ & 0.57 \\
\hline 1-Methylphenanthrene & 0.54 & $+/-$ & 0.49 & 2.00 & $+/-$ & 0.55 \\
\hline 3,6-Dimethylphenanthrene & -0.01 & $+/-$ & 0.49 & 0.54 & $+/-$ & 0.50 \\
\hline A-Dimethylphenanthrene & 0.28 & $+/-$ & 0.49 & 0.97 & $+/-$ & 0.51 \\
\hline B-Dimethylphenanthrene & -0.16 & $+/-$ & 0.48 & 0.16 & $+/-$ & 0.48 \\
\hline C-Dimethylphenanthrene & 0.91 & $+/-$ & 0.51 & 1.17 & $+/-$ & 0.52 \\
\hline 1,7-Dimethylphenanthrene & 0.27 & $+/-$ & 0.49 & 0.51 & $+/-$ & 0.48 \\
\hline D-Dimethylphenanthrene & 0.21 & $+1-$ & 0.49 & 0.38 & $+/-$ & 0.48 \\
\hline E-Dimethylphenanthrene & -0.37 & $+/-$ & 0.35 & -0.08 & $+/-$ & 0.35 \\
\hline Anthracene & 1.69 & $+/-$ & 0.55 & 8.82 & $+/-$ & 1.41 \\
\hline 9-Methylanthracene & -5.30 & $+/-$ & 1.09 & -5.22 & $+/-$ & 1.09 \\
\hline Fluoranthene & 5.25 & $+/-$ & 1.13 & 9.28 & $+/-$ & 1.48 \\
\hline Pyrene & 15.32 & $+/-$ & 1.71 & 19.21 & $+/-$ & 2.11 \\
\hline A-Methylpyrene & 0.45 & $+/-$ & 0.49 & -0.06 & $+/-$ & 0.48 \\
\hline B-Methylpyrene & 0.01 & $+/-$ & 0.48 & 0.36 & $+/-$ & 0.48 \\
\hline C-Methylpyrene & 1.19 & $+/-$ & 0.50 & 1.56 & $+/-$ & 0.51 \\
\hline D-Methylpyrene & 0.22 & $+1-$ & 0.49 & 0.35 & $+1-$ & 0.48 \\
\hline E-Methylpyrene & 0.54 & $+/-$ & 0.49 & 0.53 & $+/-$ & 0.48 \\
\hline F-Methylpyrene & 0.41 & $+/-$ & 0.69 & 0.37 & $+/-$ & 0.68 \\
\hline Retene & 0.15 & $+/-$ & 0.96 & 0.11 & $+/-$ & 0.95 \\
\hline Benzonaphthothiophene & 0.15 & $+/-$ & 1.40 & 0.11 & $+/-$ & 1.40 \\
\hline Benz(a)anthracene & 0.78 & $+/-$ & 0.56 & 0.60 & $+/-$ & 0.52 \\
\hline 7-Methylbenz[a]anthracene & -0.13 & $+/-$ & 0.72 & -0.16 & $+/-$ & 0.71 \\
\hline Chrysene & 1.03 & $+/-$ & 0.82 & 0.61 & $+/-$ & 0.80 \\
\hline Benzo $(b+j+k)$ fluoranthene & 2.69 & $+/-$ & 0.67 & 1.01 & $+/-$ & 0.51 \\
\hline Benzo(e)pyrene & 0.85 & $+/-$ & 1.54 & 0.35 & $+/-$ & 1.53 \\
\hline Benzo(a)pyrene & 0.11 & $+/-$ & 0.55 & 0.12 & $+/-$ & 0.50 \\
\hline 7-Methylbenzo[a]pyrene & -0.10 & $+/-$ & 1.29 & -0.11 & $+/-$ & 1.29 \\
\hline Indeno[1,2,3-cd]pyrene & 0.27 & $+/-$ & 1.88 & 0.12 & $+/-$ & 1.87 \\
\hline Dibenz $(a h+a c)$ anthracene & -0.01 & $+/-$ & 1.01 & -0.03 & $+/-$ & 0.97 \\
\hline Benzo(b)chrysene & -0.08 & $+/-$ & 1.67 & -0.10 & $+/-$ & 1.67 \\
\hline Benzo(ghi)perylene & 0.06 & $+/-$ & 0.60 & -0.02 & $+/-$ & 0.55 \\
\hline Coronene & 0.24 & $+/-$ & 0.10 & 0.20 & $+/-$ & 0.07 \\
\hline Total & 31.60 & & & 965.10 & & \\
\hline
\end{tabular}


Table 14. Statistics for M85 and RFG FFV Ford Taurus for USO6 PAH Emissions ( $\mu \mathrm{g} / \mathrm{mi})$

\begin{tabular}{|c|c|c|c|c|c|c|}
\hline \multirow[b]{2}{*}{ Naphthalene } & \multicolumn{3}{|c|}{ M85 Ford Taurus } & \multicolumn{3}{|c|}{ RFG Ford Taurus } \\
\hline & 9.34 & $+/-$ & 2.40 & 110.81 & $+/-$ & 12.07 \\
\hline 2-Methylnaphthalene & 9.71 & $+/-$ & 2.28 & 34.50 & $+/-$ & 4.18 \\
\hline 1-Methylnaphthalene & 4.76 & $+1-$ & 1.20 & 15.90 & $+1-$ & 2.01 \\
\hline 2,6+2,7-Dimethylnaphthalene & 2.73 & $+1-$ & 2.75 & 6.51 & $+1-$ & 2.79 \\
\hline $1,7+1,3+1,6$ & 3.85 & $+/-$ & 3.65 & 8.85 & $+/-$ & 3.72 \\
\hline Dimethylnaphthalene & & & & & & \\
\hline $2,3+1,4+1,5$ & 1.21 & $+/-$ & 5.18 & 2.68 & $+1-$ & 5.13 \\
\hline Dimethylnaphthalene & & & & & & \\
\hline 1,2-Dimethylnaphthalene & 0.38 & $+1-$ & 3.18 & 0.81 & $+/-$ & 3.14 \\
\hline 1,8-Dimethylnaphthalene & 0.00 & $+/-$ & 2.62 & 0.00 & $+/-$ & 2.59 \\
\hline Biphenyl & 0.70 & $+/-$ & 0.63 & 3.92 & $+1-$ & 0.75 \\
\hline 2-Methylbiphenyl & -10.27 & $+/-$ & 1.49 & -12.65 & $+/-$ & 1.60 \\
\hline 3-Methylbiphenyl & -3.49 & $+/-$ & 0.69 & -3.60 & $+/-$ & 0.69 \\
\hline 4-Methylbiphenyl & -1.26 & $+/-$ & 0.56 & -1.31 & $+/-$ & 0.55 \\
\hline A-Trimethylnaphthalene & 1.12 & $+/-$ & 0.50 & 1.42 & $+/-$ & 0.50 \\
\hline 1-Ethyl-2-methylnaphthalene & 0.08 & $+/-$ & 0.48 & 0.13 & $+/-$ & 0.48 \\
\hline B-Trimethylnaphthalene & 0.64 & $+/-$ & 0.50 & 0.83 & $+/-$ & 0.50 \\
\hline C-Trimethylnaphthalene & 0.51 & $+/-$ & 0.49 & 0.77 & $+1-$ & 0.49 \\
\hline 2-Ethyl-1-methylnaphthalene & 0.00 & $+/-$ & 0.48 & 0.01 & $+1-$ & 0.48 \\
\hline E-Trimethylnaphthalene & 0.43 & $+/-$ & 0.49 & 0.55 & $+1-$ & 0.49 \\
\hline F-Trimethylnaphthalene & 0.71 & $+/-$ & 0.49 & 0.92 & $+/-$ & 0.49 \\
\hline G-Trimethylnaphthalene & 0.21 & $+/-$ & 0.50 & 0.27 & $+/-$ & 0.49 \\
\hline H-Trimethylnaphthalene & -0.13 & $+/-$ & 0.48 & -0.16 & $+/-$ & 0.48 \\
\hline $1,2,8$-Trimethylnaphthalene & -0.06 & $+/-$ & 0.49 & -0.07 & $+/-$ & 0.48 \\
\hline Acenaphthylene & 0.06 & $+1-$ & 3.14 & 0.69 & $+1-$ & 3.11 \\
\hline Acenaphthene & 0.13 & $+/-$ & 1.42 & 0.25 & $+/-$ & 1.40 \\
\hline Phenanthrene & 3.74 & $+/-$ & 0.83 & 11.70 & $+1-$ & 1.47 \\
\hline Fluorene & 0.27 & $+/-$ & 0.57 & 2.25 & $+1-$ & 0.62 \\
\hline A-Methylfluorene & 0.21 & $+/-$ & 0.49 & 0.49 & $+/-$ & 0.49 \\
\hline 1-Methylfluorene & 0.25 & $+1-$ & 0.49 & 0.72 & $+1-$ & 0.49 \\
\hline B-Methylfluorene & -2.02 & $+/-$ & 0.57 & -1.90 & $+1-$ & 0.57 \\
\hline C-Methylfluorene & 4.25 & $+/-$ & 0.80 & 10.10 & $+1-$ & 1.48 \\
\hline A-Methylphenanthrene & -0.26 & $+/-$ & 0.50 & 0.22 & $+/-$ & 0.51 \\
\hline 2-Methylphenanthrene & 0.51 & $+/-$ & 0.49 & 1.22 & $+/-$ & 0.50 \\
\hline B-Methylphenanthrene & -0.32 & $+/-$ & 0.48 & -0.36 & $+1-$ & 0.48 \\
\hline C-Methylphenanthrene & -0.34 & $+/-$ & 0.49 & -0.15 & $+/-$ & 0.49 \\
\hline 1-Methylphenanthrene & 0.05 & $+/-$ & 0.49 & 0.37 & $+1-$ & 0.48 \\
\hline 3,6-Dimethylphenanthrene & -0.18 & $+/-$ & 0.48 & -0.08 & $+/-$ & 0.48 \\
\hline A-Dimethylphenanthrene & -0.01 & $+/-$ & 0.48 & 0.11 & $+/-$ & 0.48 \\
\hline B-Dimethylphenanthrene & -0.30 & $+/-$ & 0.48 & -0.24 & $+/-$ & 0.48 \\
\hline C-Dimethylphenanthrene & 0.06 & $+/-$ & 0.49 & 0.13 & $+/-$ & 0.48 \\
\hline 1,7-Dimethylphenanthrene & -0.09 & $+/-$ & 0.48 & 0.00 & $+1-$ & 0.48 \\
\hline D-Dimethylphenanthrene & -0.07 & $+/-$ & 0.48 & -0.01 & $+/-$ & 0.48 \\
\hline E-Dimethylphenanthrene & -0.66 & $+/-$ & 0.36 & -0.60 & $+1-$ & 0.35 \\
\hline Anthracene & 0.69 & $+/-$ & 0.49 & 2.88 & $+1-$ & 0.65 \\
\hline 9-Methylanthracene & -5.68 & $+1-$ & 1.11 & -5.47 & $+1-$ & 1.10 \\
\hline Fluoranthene & -3.65 & $+/-$ & 0.78 & 0.48 & $+1-$ & 0.82 \\
\hline Pyrene & 4.69 & $+/-$ & 0.74 & 8.89 & $+1-$ & 1.09 \\
\hline A-Methylpyrene & -0.19 & $+/-$ & 0.49 & -0.17 & $+1-$ & 0.48 \\
\hline B-Methylpyrene & -0.34 & $+/-$ & 0.48 & -0.17 & $+/-$ & 0.48 \\
\hline C-Methylpyrene & 0.29 & $+1-$ & 0.49 & 0.67 & $+/-$ & 0.48 \\
\hline D-Methylpyrene & -0.06 & $+1-$ & 0.48 & 0.00 & $+1-$ & 0.48 \\
\hline E-Methylpyrene & 0.05 & $+/-$ & 0.48 & 0.14 & $+/-$ & 0.48 \\
\hline F-Methylpyrene & 0.02 & $+/-$ & 0.68 & 0.18 & $+/-$ & 0.68 \\
\hline Retene & 0.02 & $+/-$ & 0.96 & 0.02 & $+1-$ & 0.95 \\
\hline Benzonaphthotiophene & 0.00 & $+/-$ & 1.40 & 0.02 & $+1-$ & 1.40 \\
\hline Benz(a)anthracene & 0.10 & $+/-$ & 0.54 & 0.15 & $+1-$ & 0.50 \\
\hline 7-Methylbenz[a]anthracene & -0.14 & $+/-$ & 0.72 & -0.15 & $+/-$ & 0.71 \\
\hline Chrysene & 0.04 & $+/-$ & 0.79 & 0.14 & $+/-$ & 0.79 \\
\hline Benzo $(b+j+k)$ fluoranthene & 0.03 & $+/-$ & 0.50 & 0.13 & $+/-$ & 0.48 \\
\hline Benzo(e)pyrene & 0.03 & $+/-$ & 1.53 & 0.05 & $+1-$ & 1.53 \\
\hline Benzo(a)pyrene & -0.02 & $+/-$ & 0.55 & -0.02 & $+/-$ & 0.50 \\
\hline 7-Methylbenzo[a]pyrene & -0.11 & $+/-$ & 1.29 & -0.11 & $+/-$ & 1.29 \\
\hline Indeno[1,2,3-cd]pyrene & -0.02 & $+/-$ & 1.88 & -0.01 & $+/-$ & 1.87 \\
\hline Dibenz $(a h+a c)$ anthracene & -0.02 & $+/-$ & 1.01 & -0.02 & $+/-$ & 0.97 \\
\hline Benzo(b)chrysene & -0.10 & $+/-$ & 1.67 & -0.10 & $+1-$ & 1.67 \\
\hline Benzo(ghi)perylene & -0.45 & $+/-$ & 0.60 & -0.41 & $+1-$ & 0.55 \\
\hline Coronene & 0.03 & $+/-$ & 0.09 & 0.04 & $+1-$ & 0.05 \\
\hline Total & 21.65 & & & 203.08 & & \\
\hline
\end{tabular}




\subsection{Summary of Results}

The findings of this study are as follows:

- $\quad$ Average FTP particulate emissions for CNG and M85 fueled vehicles were 1.40 and 0.70 $\mathrm{mg} / \mathrm{mi}$, respectively. These particulate emission values are low and comparable to those of their gasoline counterparts.

- $\quad \mathrm{CNG}$ vehicles produced considerably lower NMHC than RFG vehicles, with reductions of 83\% for the FTP and 93\% for the US06. CO emissions for CNG vehicles were also lower compared with RFG, with reductions of $38 \%$ and $85 \%$, respectively, for the FTP and the US06. Reductions in NMHC and $\mathrm{CO}$ were even greater when the contribution from the highest-emitting CNG Dodge Caravan was removed from the average. $\mathrm{NO}_{\mathrm{x}}$ emissions for CNG vehicles were comparable to those for the gasoline vehicles for the fleet average, and lower than RFG when CNG vehicle \#1 was excluded.

- $\quad$ M85 produced 27\% lower $\mathrm{NO}_{\mathrm{x}}$ and 36\% higher $\mathrm{CO}$ emissions than RFG over the FTP. OMHCE emissions were 38\% higher on M85 compared with RFG. Total hydrocarbons excluding methanol were lower for M85 than RFG, however.

- $\quad$ M85 produced lower emissions than RFG for THC, NMHC, CO, and $\mathrm{NO}_{\mathrm{x}}$ over the US06 cycle. The reductions for M85 relative to RFG were $68 \%, 72 \%, 33 \%$, and 44\%, respectively, for $\mathrm{THC}, \mathrm{NMHC}, \mathrm{CO}$, and $\mathrm{NO}_{\mathrm{x}}$.

- $\quad$ FTP average mass-emission rates for methanol and formaldehyde were $224 \mathrm{mg} / \mathrm{mi}$ and 19 $\mathrm{mg} / \mathrm{mi}$, respectively. Methanol emissions were primarily attributable to cold-start emissions. Methanol and formaldehyde emissions were very low for RFG over the FTP and US06, and for M85 over the US06.

- $\quad$ Particulate, $\mathrm{NO}_{\mathrm{x}}$, and $\mathrm{CO}$ emissions were significantly higher for the more aggressive US06 cycle than the FTP for all vehicle/fuel combinations, with some vehicles having significant increases in particulate emissions over the US06. Average US06 particulate emissions were 7.76 and $3.62 \mathrm{mg} / \mathrm{mi}$, respectively, for CNG and M85 vehicles, or a factor of more than 5 greater than the FTP values. Increases relative to the FTP of $72 \%$ and $103 \%$ were observed for $\mathrm{CO}$ and $\mathrm{NO}_{\mathrm{x}}$, respectively, for CNG vehicles over the US06. Increases relative to the FTP of $212 \%$ and $143 \%$ were observed for $\mathrm{CO}$ and $\mathrm{NO}_{\mathrm{x}}$, respectively, for M85 vehicles over the US06.

- $\quad$ Most of the particulate mass was below $10 \mu \mathrm{m}$ in aerodynamic diameter (77\%-92\%) with $58 \%-82 \%$ of the mass below $2.5 \mu \mathrm{m}$, and $42 \%-77 \%$ below $1.0 \mu \mathrm{m}$. The fractions of particulate in the smallest size regions are slightly lower than those observed in previous studies, which could indicate a greater contribution of re-entrained particulate. It should also be noted that low particulate emissions made the measurement of particulate size distributions difficult, especially over the FTP cycle. 
- Analysis of particulate samples for organic and elemental carbon, trace elements, and ions revealed that elemental and organic carbon were prominent constituents for all three vehicle groups. Other species identified include possible fuel-derived components $\left(\mathrm{SO}_{4}{ }^{2-}, \mathrm{S}\right)$ and oil/wear-derived components ( $\mathrm{Mg}, \mathrm{P}, \mathrm{Ca}, \mathrm{Zn}, \mathrm{Fe}, \mathrm{Si}$, and $\mathrm{Al})$. Low emissions levels and large sample-to-sample variability made it difficult to differentiate between the species profiles for different vehicle/fuel combinations.

- $\quad$ PAH emissions were highest for the RFG vehicles over the FTP and the US06. Naphthalene, methylnaphthalenes, and dimethylnaphthalenes were the primary PAH constituents for the RFG vehicles. PAH emissions for M85 vehicles were lower than for RFG vehicles over the FTP and considerably lower over the US06. Naphthalene and methylnaphthalenes were the most prominent PAHs for M85 vehicles. PAH emissions for CNG vehicles were lower than for RFG vehicles over the FTP and US06 cycles, and lower than those for M85 vehicles over the FTP. For CNG, most PAH compounds were identified in relatively low concentrations, and naphthalene and methylnaphthalenes were not identified.

- $\quad$ Hopane and sterane emissions were not measured above the detectable levels for any of the vehicle/fuel groups, indicating that no test vehicles were excessive oil burners. 


\subsection{Conclusions and Recommendations}

Overall, particulate emissions from modern technology CNG and M85 vehicles were low, but comparable to those of similar technology gasoline vehicles. These results indicate that the replacement of gasoline vehicles with AFVs will probably not provide a dramatic reduction in particulate emissions in urban areas. Previous studies have shown more dramatic reductions in PM for alternative fuels used in diesel applications, and research in this area should continue (Wang et al., 1993; Unnasch et al, 1993). AFVs also can provide reductions in gaseous emissions compared with gasoline vehicles. This should be considered in developing air quality management plans.

The results of this study indicate that driving conditions can have a important impact on particulate emissions. This applies even for low-emitting gasoline and alternative fuel vehicles, which showed significant increases over the US06 compared with the FTP. It is recommended that additional studies comparing particulate emissions for the FTP and more aggressive cycles be conducted. Such studies should include larger fleets of vehicles and chemical analyses to help identify the source of the particulate.

The results of this study highlight the difficulty of measuring PM emissions from modern technology low emitting gasoline and alternative fuel vehicles. This is particularly true in the case of measuring size distributions and for chemical analyses, but it also applies to mass emissions. In each case, multiple cycles are required to obtain sufficient mass for analysis.

As particulate emissions from modern technology vehicles continue to decrease to near detectable limits, more advanced methodologies for measuring particulate must be investigated. In this regard, more extensive research in the development of real-time particulate measurement techniques, such as a condensation nuclei counter or spectrophone, should be conducted. Further development of such techniques will also be useful in measuring and determining the origin of particulate emissions from higher emitting gasoline and diesel vehicles. 


\subsection{References}

Burns, V.R.; Benson, J.D.; Hochhauser, A.M.; Koehl, W.J.; Kreucher, W.M.; and Reuter, R.M. (1991). "Description of Auto/Oil Air Quality Improvement Research Program." SAE Technical Paper No. 912320.

Cadle, S.H.; Mulawa, P.A.; Ball, J.; Donase, C.; Weibel, A.; Sagebiel, J.; Knapp, K.; and Snow, R. (1997). "Particulate and Speciated HC Emission Rates from In-Use Vehicles Recruited in Orange County, CA.” Environ. Sci. Technol., 31:3405-3412.

Chow, J.C.; Watson, J.G; Pritchasett, L.C.; Pierson, W.R.; Frazer, C.A.; and Purcell, R.G. (1993). "Thermal/Optical Reflectance Carbon Analysis System: Description, Evaluation and Application in U.S. Air Quality Studies.” Atmospheric Environment, 27A:1185.

Dickson, E.L.; Henning, R.C.; and Oliver, W.R. (1991). Evaluation of Vehicle Emissions from the Unocal SCRAP Program. Radian Corporation Report No. 264-127-06-01, June.

Dockery, D.W.; and Pope, C.A. III (1994). "Acute Respiratory Effects of Particulate Air Pollution." Annu. Rev. Public Health, 15:107-132.

Durbin, T.D.; Smith, M.R.; Norbeck, J.M.; and Truex, T.J. (1999). "Population Density, Particulate Emission Characterization, and Impact on the Particulate Inventory of Smoking Vehicles in the South Coast Air Quality Management District.” J. Air \& Waste Manage. Assoc. In press.

Hammerle, R.H.; Korniski, T.J.; Weir, J.E.; Chladek, E.; Gierczak, C.A.; and Hurley, R.G. (1991). "Particulate Emissions from Current Model Vehicles Using Gasoline with Methylcyclopentadienyl Manganese Tricarbonyl." SAE Technical Paper No. 912436.

Health Effects Institute (1995). Particulate Air Pollution and Daily Mortality: Replication and Validation of Selected Studies. Cambridge, MA.

Hildemann, L.M.; Markowski, G.R.; and Cass, G.R. (1991). "Chemical Composition of Emissions from Urban Sources of Fine Organic Aerosol.” Environ. Sci. Technol., 25: 744.

Marple, V.A.; Kittleson, D.B.; Rubow, K.L.; and Fang, C. (1986). Methods for the Selective Sampling of Diesel Particulate in Mine Dust Aerosols. Bureau of Mines Contract No. J0145022, Univ. Of Minn., p. 94.

Norbeck, J.M.; Durbin, T.D.; and Truex, T.J. (1998). Measurement of Primary Particulate Matter Emissions from Light-Duty Motor Vehicles. Final report for Coordinating Research Council and South Coast Air Quality Management District.

Sagebiel, J.; Zielinska, B.; Walsh, P.; Chow, J.; Cadle, S.; Mulawa, P.; Knapp, K.; Zweidinger, R.; and Snow, R. (1997). "PM10 Dynamometer Exhaust Samples Collected from In-Service Vehicles in Nevada.” Environ. Sci. Technol. 31:75. 
Siegel, W.O.; Zinbo, M.; Korniski, T.J.; Richert, J.F.O.; Chladek, E.; Paputa Peck, M.C.; Weir, J.E.; Schuetzle, D.; and Jensen, T.E. (1994). "Air Toxics: A Comparison of the Gas- and Particle-Phase Emissions from a High-Emitter Vehicle with Those from a Normal-Emitter Vehicle," SAE Technical Paper No. 940581.

Sinclair, S., Southern California Gas Co., personal communication.

Unnasch, S.; Lowell, D.; Lonyai, F.; Dunlap, L.; and Sullivan, C. (1993). "Performance and Emissions of Clean Fuels in Transit Buses with Cummins L10 Engines." SAE Technical Paper No. 931782.

Wang, W.; Sun, X.; Bata, R.; Gautam, M.; Clark, N.; Palmer, G.M.; and Lyons, D. (1993). "A Study of Emissions from CNG and Diesel Fueled Heavy-Duty Vehicles." SAE Technical Paper No. 932826.

Watson, J.G.; Chow, J.C.; Lowenthal, D.H.; Pritchett, L.C.; Frazier, C.A.; Neuroth, G.R.; and Robbins, R.; (1994). "Differences in the Carbon Composition of Source Profiles for Diesel- and Gasoline-Powered Vehicles," Atmospheric Environment, 28: 2493.

Whitney, K.A. (1998). "Characterization of Particulate Exhaust Emissions from In-Use Light-Duty Vehicles." Proceedings of the $8^{\text {th }}$ CRC On-Road Vehicle Emissions Workshop, San Diego, CA, April.

Whitney, K.A. (1997). Determination of Alternative Fuels Combustion Products: Phase 3 Report. Final report for National Renewable Energy Laboratory, Report \# NREL/SR-540-23594, December.

Zinbo, M.; Korniski, T.J.; and Weir, T.E. (1995). "Relationship between the Composition of Engine Particulate Emissions and Emission Control System Performance.” Ind. Eng. Chem. Res., 34:619. 


\section{Appendix A: Fuel Properties}


Table A-1. Fuel Properties for RFG

\begin{tabular}{lcccc}
\multicolumn{1}{r}{ Fuel Parameter } & Units & \multicolumn{3}{r}{ California Phase 2 Gasoline } \\
& & Specs. & $\begin{array}{c}\text { Phillips } \\
\text { Analyses }\end{array}$ & $\begin{array}{c}\text { Verification } \\
\text { Analyses }\end{array}$ \\
Octane & - & 91 Min. & 91.7 & \\
Distillation & & & & \\
10\% Point & Deg. F & $130-150$ & 139 & 150 \\
50\% Point & Deg. F & $200-210$ & 203 & 205 \\
90\% Point & Deg. F & $290-300$ & 300 & 296 \\
End Point & Deg. F & 390 max. & 379 & 378 \\
Sulfur & Ppmw & $30-40$ & 32.5 & 34.5 \\
RVP & Psi & $6.7-7.0$ & 6.9 & 6.74 \\
Olefins & Vol \% & $4-6$ & 5.8 & 5.29 \\
Aromatics & Vol \% & $22-25$ & 24.2 & 23.44 \\
Multi-Substituted & Vol \% & $12-14$ & 14 & \\
Alkyl Aromatics & & & & \\
Benzene & Vol \% & $0.8-1.0$ & 0.95 & 0.88 \\
MTBE & Vol \% & $10.8-11.2$ & 10.92 & 10.86
\end{tabular}

Table A-2. Fuel Properties for M85 Blend (w/RFG)

\begin{tabular}{lcc}
\multicolumn{1}{r}{ Fuel Parameter } & Units & \\
API Gravity & - & 45.4 \\
Sulfur & ppmw & 2.5 \\
RVP & Psi & 5.2 \\
Olefins & Vol \% & 0.60 \\
Aromatics & Vol \% & 2.99 \\
Methanol & Vol \% & 88.3 \\
Paraffins & Vol \% & 5.12 \\
Benzene & Vol \% & 0.11 \\
MTBE & Vol \% & 1.39
\end{tabular}

\section{Table A-3. Fuel Properties for CNG (\% Mass)}

Fuel Species $\quad \%$ of total hydrocarbons (by Mass)

$\begin{array}{lc}\text { Methane } & 95.8 \% \\ \text { Ethane } & 2.8 \% \\ \text { Propane } & 0.7 \% \\ \text { Butane } & 0.3 \% \\ \text { Pentane } & 0.2 \% \\ \text { 2,2-Dimethylpropane } & 0.0 \% \\ \text { 2-Methylbutane } & 0.2 \% \\ \text { Propene } & 0.1 \%\end{array}$

Note: inert compounds were not measured in this study, but average approximately $1.41 \% \mathrm{CO}_{2}$ and $0.46 \% \mathrm{~N}_{2}$ by volume at the Riverside distribution point (Sinclair) 
Appendix B: Particulate and Gas-Phase

Emissions Summary for FTP and US06 
Table B-1. Particulate and Gas-Phase Emissions Summary for FTP

\begin{tabular}{|c|c|c|c|c|c|c|c|c|c|c|c|c|c|c|c|c|c|c|c|c|c|}
\hline & & \multicolumn{5}{|c|}{ Bag 1} & \multicolumn{5}{|c|}{ Bag 2} & \multicolumn{5}{|c|}{ Bag 3} & \multicolumn{5}{|c|}{ Weighted } \\
\hline & & $\begin{array}{l}\mathrm{THC} \\
\mathrm{g} / \mathrm{mi}\end{array}$ & $\begin{array}{c}\mathrm{NMHC} \\
\mathrm{g} / \mathrm{mi}\end{array}$ & $\begin{array}{l}\mathrm{CO} \\
\mathrm{g} / \mathrm{mi}\end{array}$ & $\begin{array}{l}\mathrm{NO}_{x} \\
\mathrm{~g} / \mathrm{mi}\end{array}$ & $\begin{array}{c}\mathrm{PM} \\
\mathrm{mg} / \mathrm{mi}\end{array}$ & $\begin{array}{l}\mathrm{THC} \\
\mathrm{g} / \mathrm{mi}\end{array}$ & $\begin{array}{c}\mathrm{NMHC} \\
\mathrm{g} / \mathrm{mi}\end{array}$ & $\begin{array}{l}\mathrm{CO} \\
\mathrm{g} / \mathrm{mi}\end{array}$ & $\begin{array}{l}\mathrm{NO}_{\mathrm{x}} \\
\mathrm{g} / \mathrm{mi}\end{array}$ & $\begin{array}{c}\mathrm{PM} \\
\mathrm{mg} / \mathrm{mi}\end{array}$ & $\begin{array}{l}\mathrm{THC} \\
\mathrm{g} / \mathrm{mi}\end{array}$ & $\begin{array}{c}\mathrm{NMHC} \\
\mathrm{g} / \mathrm{mi}\end{array}$ & $\begin{array}{l}\mathrm{CO} \\
\mathrm{g} / \mathrm{mi}\end{array}$ & $\begin{array}{l}\mathrm{NO}_{\mathrm{x}} \\
\mathrm{g} / \mathrm{mi}\end{array}$ & $\begin{array}{c}\mathrm{PM} \\
\mathrm{mg} / \mathrm{mi}\end{array}$ & $\begin{array}{l}\mathrm{THC} \\
\mathrm{g} / \mathrm{mi}\end{array}$ & $\begin{array}{c}\mathrm{NMHC} \\
\mathrm{g} / \mathrm{mi}\end{array}$ & $\begin{array}{l}\mathrm{CO} \\
\mathrm{g} / \mathrm{mi}\end{array}$ & $\begin{array}{l}\mathrm{NO}_{\mathrm{x}} \\
\mathrm{g} / \mathrm{mi}\end{array}$ & $\begin{array}{c}\mathrm{PM} \\
\mathrm{mg} / \mathrm{mi}\end{array}$ \\
\hline \multirow[t]{2}{*}{ CNG \#1 } & FTP \#1 & 1.075 & 0.095 & 5.648 & 1.460 & 1.30 & 0.986 & 0.082 & 4.226 & 1.163 & 1.09 & 0.754 & 0.065 & 5.041 & 1.390 & 0.48 & 0.941 & 0.08 & 4.744 & 1.287 & 0.96 \\
\hline & FTP \#2 & 1.049 & 0.101 & 5.603 & 1.407 & & 0.951 & 0.081 & 4.315 & 1.120 & & 0.762 & 0.065 & 5.171 & 1.369 & & 0.919 & 0.081 & 4.816 & 1.248 & \\
\hline \multirow[t]{2}{*}{$\mathrm{CNG} \# 2$} & FTP \#1 & 0.729 & 0.083 & 1.392 & 0.775 & 3.12 & 0.271 & 0.044 & 0.273 & 0.357 & 2.34 & 0.324 & 0.034 & 0.808 & 0.320 & 1.47 & 0.38 & 0.05 & 0.651 & 0.433 & 2.26 \\
\hline & FTP \#2 & 0.592 & 0.018 & 1.418 & 0.682 & & 0.247 & 0.054 & 0.270 & 0.275 & & 0.311 & 0.023 & 0.553 & 0.297 & & 0.336 & 0.038 & 0.585 & 0.365 & \\
\hline \multirow[t]{2}{*}{ CNG \#3 } & FTP \#1 & 0.487 & 0.041 & 1.595 & 0.222 & 1.30 & 0.101 & 0.126 & 0.375 & 0.007 & 2.09 & 0.164 & 0.018 & 0.751 & 0.043 & 1.40 & 0.198 & 0.078 & 0.731 & 0.061 & 1.74 \\
\hline & FTP \#2 & 0.339 & 0.043 & 1.169 & 0.156 & & 0.089 & 0.043 & 0.343 & 0.008 & & 0.178 & 0.000 & 0.826 & 0.039 & & 0.165 & 0.031 & 0.646 & 0.047 & \\
\hline \multirow[t]{2}{*}{ CNG \#4 } & FTP \#1 & 0.476 & 0.010 & 0.751 & 0.673 & 1.04 & 0.126 & 0.034 & 0.013 & 0.414 & 1.36 & 0.21 & 0.017 & 0.033 & 0.424 & 0.85 & 0.221 & 0.024 & 0.171 & 0.470 & 1.16 \\
\hline & FTP \#2 & 0.46 & 0.037 & 1.035 & 0.681 & & 0.118 & 0.027 & 0.010 & 0.374 & & 0.197 & 0.026 & 0.061 & 0.412 & & 0.211 & 0.029 & 0.236 & 0.448 & \\
\hline \multirow[t]{2}{*}{ CNG \#5 } & FTP \#1 & 0.486 & 0.013 & 2.159 & 0.412 & 1.91 & 0.071 & 0.000 & 0.061 & 0.104 & 0.63 & 0.173 & 0.000 & 0.429 & 0.110 & 0.55 & 0.184 & 0.003 & 0.595 & 0.169 & 0.87 \\
\hline & FTP \#2 & 0.454 & 0.000 & 2.206 & 0.399 & & 0.094 & 0.013 & 0.081 & 0.176 & & 0.18 & 0.008 & 0.361 & 0.114 & & 0.192 & 0.009 & 0.597 & 0.205 & \\
\hline \multirow[t]{2}{*}{ RFG \#1 } & FTP \#1 & 0.875 & 0.816 & 5.973 & 0.865 & 9.06 & 0.055 & 0.032 & 0.577 & 0.189 & 0.44 & 0.146 & 0.111 & 1.864 & 0.317 & 0.94 & 0.25 & 0.216 & 2.047 & 0.364 & 2.36 \\
\hline & FTP \#2 & & N.A. & & & & & N.A. & & & & & N.A. & & & & & N.A. & & & \\
\hline \multirow[t]{2}{*}{ RFG \#2 } & FTP \#1 & 0.861 & 0.818 & 7.269 & 0.799 & 1.35 & 0.024 & 0.013 & 0.276 & 0.159 & 0.16 & 0.085 & 0.062 & 1.297 & 0.287 & 0.28 & 0.214 & 0.193 & 1.999 & 0.326 & 0.44 \\
\hline & FTP \#2 & 1.184 & 1.121 & 8.228 & 0.729 & & 0.038 & 0.006 & 0.274 & 0.178 & & 0.111 & 0.094 & 1.243 & 0.277 & & 0.295 & 0.261 & 2.186 & 0.320 & \\
\hline \multirow[t]{2}{*}{ RFG \#3 } & FTP \#1 & 1.214 & 1.151 & 7.570 & 0.859 & 4.21 & 0.026 & 0.013 & 0.395 & 0.165 & 0.34 & 0.12 & 0.111 & 1.457 & 0.196 & 1.09 & 0.297 & 0.275 & 2.17 & 0.317 & 1.35 \\
\hline & FTP \#2 & 1.402 & 1.348 & 6.311 & 0.881 & & 0.047 & 0.007 & 0.614 & 0.140 & & 0.121 & 0.13 & 1.612 & 0.191 & & 0.347 & 0.318 & 2.064 & 0.307 & \\
\hline \multirow[t]{2}{*}{ RFG \#4 } & FTP \#1 & 1.181 & 1.125 & 5.555 & 0.957 & 2.51 & 0.069 & 0.045 & 0.86 & 0.224 & 0.53 & 0.149 & 0.121 & 2.150 & 0.313 & 1.32 & 0.321 & 0.289 & 2.184 & 0.400 & 1.16 \\
\hline & FTP \#2 & 0.939 & 0.884 & 5.350 & 0.939 & & 0.054 & 0.030 & 1.054 & 0.223 & & 0.145 & 0.112 & 2.282 & 0.377 & & 0.262 & 0.229 & 2.277 & 0.413 & \\
\hline \multirow[t]{2}{*}{ RFG \#5 } & FTP \#1 & 1.126 & 1.062 & 7.606 & 0.979 & 2.49 & 0.059 & 0.036 & 0.954 & 0.232 & 0.55 & 0.121 & 0.089 & 1.910 & 0.374 & 0.46 & 0.297 & 0.263 & 2.591 & 0.425 & 0.92 \\
\hline & FTP \#2 & 0.931 & 0.875 & 6.297 & 0.911 & & 0.062 & 0.039 & 0.973 & 0.213 & & 0.145 & 0.112 & 2.539 & 0.383 & & 0.265 & 0.232 & 2.505 & 0.404 & \\
\hline
\end{tabular}


Table B-1. Particulate and Gas-Phase Emissions Summary for FTP (concluded)

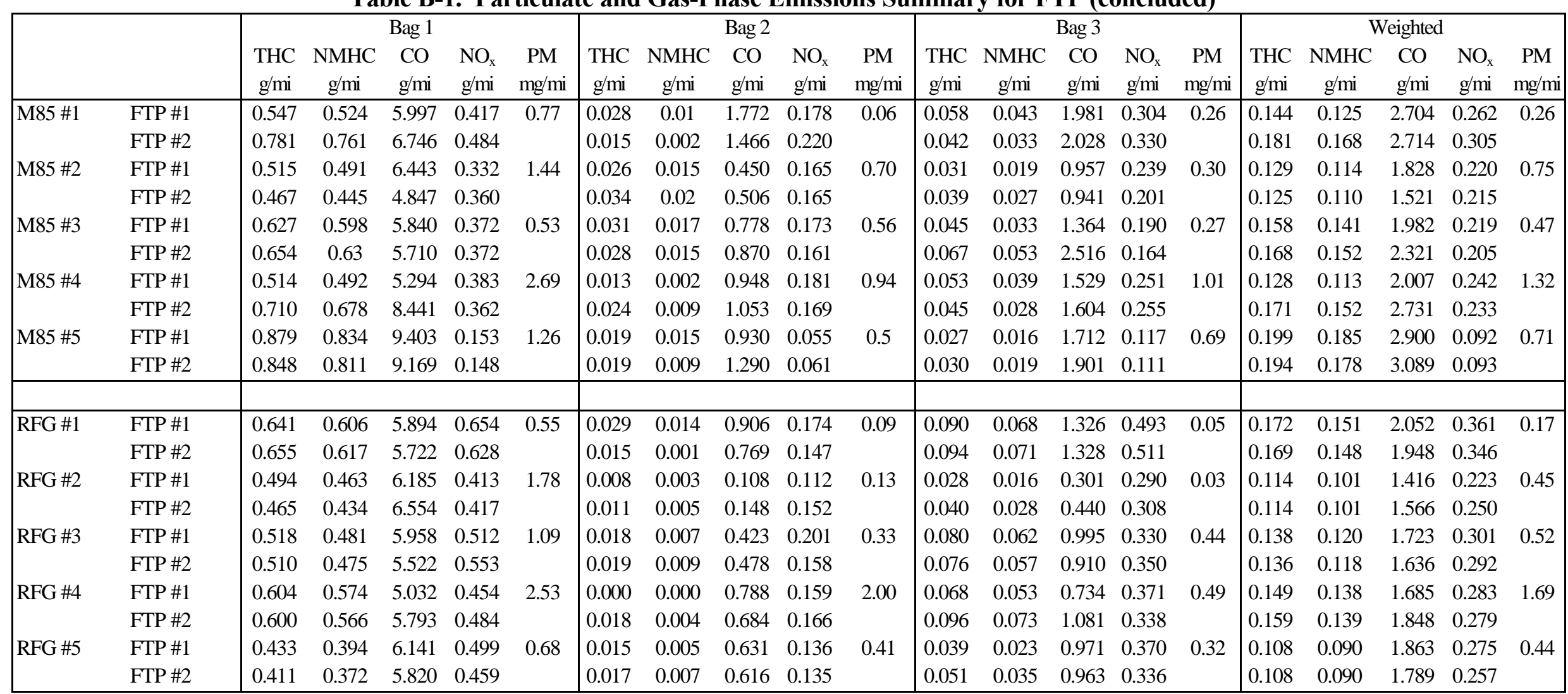


Table B-2. Particulate and Gas-Phase Emissions Summary for US06

Dodge Caravans

\begin{tabular}{|c|c|c|c|c|c|c|c|c|c|c|c|c|c|}
\hline & & $\begin{array}{l}\text { THC } \\
\mathrm{g} / \mathrm{mi}\end{array}$ & $\begin{array}{c}\text { NMHC } \\
\mathrm{g} / \mathrm{mi}\end{array}$ & $\begin{array}{l}\mathrm{CO} \\
\mathrm{g} / \mathrm{mi}\end{array}$ & $\begin{array}{c}\mathrm{NO}_{\mathrm{x}} \\
\mathrm{g} / \mathrm{mi}\end{array}$ & $\begin{array}{c}\mathrm{PM} \\
\mathrm{mg} / \mathrm{mi}\end{array}$ & & & $\begin{array}{l}\text { THC } \\
\mathrm{g} / \mathrm{mi}\end{array}$ & $\begin{array}{c}\text { NMHC } \\
\mathrm{g} / \mathrm{mi}\end{array}$ & $\begin{array}{c}\mathrm{CO} \\
\mathrm{g} / \mathrm{mi}\end{array}$ & $\begin{array}{l}\mathrm{NO}_{\mathrm{x}} \\
\mathrm{g} / \mathrm{mi}\end{array}$ & $\begin{array}{c}\mathrm{PM} \\
\mathrm{mg} / \mathrm{mi}\end{array}$ \\
\hline \multirow[t]{4}{*}{ CNG \#1 } & US06 \#1 & 0.583 & 0.057 & 5.809 & 2.944 & \multirow[t]{4}{*}{12.46} & \multirow[t]{4}{*}{ RFG \#1 } & US06 \#1 & 0.300 & 0.252 & 15.483 & 0.761 & \multirow[t]{4}{*}{7.99} \\
\hline & US06 \#2 & 0.580 & 0.052 & 7.047 & 3.011 & & & US06 \#2 & 0.200 & 0.168 & 5.302 & 0.697 & \\
\hline & US06 \#3 & 0.575 & 0.055 & 7.018 & 3.260 & & & US06 \#3 & 0.195 & 0.151 & 5.242 & 0.715 & \\
\hline & US06 \#4 & 0.569 & 0.056 & 6.866 & 3.320 & & & US06 \#4 & 0.250 & 0.205 & 10.313 & 0.674 & \\
\hline \multirow[t]{4}{*}{$\mathrm{CNG} \# 2$} & US06 \#1 & 0.169 & 0.000 & 1.757 & 0.596 & \multirow[t]{4}{*}{5.24} & \multirow[t]{4}{*}{ RFG \#2 } & US06 \#1 & 0.183 & 0.146 & 10.82 & 0.594 & \multirow[t]{4}{*}{1.83} \\
\hline & US06 \#2 & 0.199 & 0.012 & 1.727 & 0.632 & & & US06 \#2 & 0.139 & 0.113 & 8.805 & 0.440 & \\
\hline & US06 \#3 & 0.16 & 0.013 & 1.912 & 0.634 & & & US06 \#3 & 0.135 & 0.103 & 7.932 & 0.462 & \\
\hline & US06 \#4 & 0.163 & 0.022 & 1.829 & 0.627 & & & US06 \#4 & 0.181 & 0.143 & 15.483 & 0.453 & \\
\hline \multirow[t]{2}{*}{ CNG \#3 } & US06 \#1 & 0.109 & 0.000 & 1.365 & 0.281 & \multirow[t]{2}{*}{4.74} & \multirow[t]{2}{*}{ RFG \#3 } & US06 \#1 & 0.333 & 0.277 & 20.494 & 0.589 & \multirow[t]{2}{*}{11.63} \\
\hline & US06 \#2 & 0.127 & 0.006 & 1.664 & 0.226 & & & US06 \#2 & 0.255 & 0.209 & 14.229 & 0.536 & \\
\hline \multirow[t]{2}{*}{ CNG \#4 } & US06 \#1 & 0.157 & 0.012 & 0.494 & 0.455 & \multirow[t]{2}{*}{13.77} & \multirow[t]{2}{*}{ RFG \#4 } & US06 \#1 & 0.449 & 0.371 & 29.526 & 0.739 & \multirow[t]{2}{*}{7.95} \\
\hline & US06 \#2 & 0.133 & 0.002 & 0.352 & 0.461 & & & US06 \#2 & 0.370 & 0.307 & 21.375 & 0.783 & \\
\hline \multirow[t]{2}{*}{ CNG \#5 } & US06 \#1 & 0.122 & 0.006 & 1.381 & 0.353 & \multirow[t]{2}{*}{2.60} & \multirow[t]{2}{*}{ RFG \#5 } & US06 \#1 & 0.283 & 0.235 & 15.922 & 0.872 & \multirow[t]{2}{*}{3.74} \\
\hline & US06 \#2 & 0.122 & 0.009 & 1.483 & 0.316 & & & US06 \#2 & 0.296 & 0.241 & 21.637 & 0.884 & \\
\hline
\end{tabular}

Ford Tauruses

\begin{tabular}{|c|c|c|c|c|c|c|c|c|c|c|c|c|c|}
\hline \multirow[t]{4}{*}{ M85 \#1 } & US06 \#1 & 0.018 & 0.014 & 2.257 & 1.053 & \multirow[t]{4}{*}{2.91} & \multirow[t]{4}{*}{ RFG \#1 } & US06 \#1 & 0.304 & 0.276 & 8.188 & 1.442 & \multirow[t]{4}{*}{2.62} \\
\hline & US06 \#2 & 0.023 & 0.020 & 2.208 & 1.036 & & & US06 \#2 & 0.275 & 0.246 & 9.552 & 1.204 & \\
\hline & US06 \#3 & 0.018 & 0.016 & 2.672 & 0.85 & & & US06 \#3 & 0.232 & 0.211 & 4.885 & 1.414 & \\
\hline & US06 \#4 & 0.015 & 0.013 & 2.441 & 0.848 & & & US06 \#4 & 0.223 & 0.198 & 6.897 & 1.435 & \\
\hline \multirow[t]{4}{*}{ M85 \#2 } & US06 \#1 & 0.020 & 0.013 & 2.237 & 0.639 & \multirow[t]{4}{*}{3.50} & \multirow[t]{4}{*}{ RFG \#2 } & US06 \#1 & 0.073 & 0.062 & 3.194 & 0.922 & \multirow[t]{4}{*}{2.47} \\
\hline & US06 \#2 & 0.036 & 0.031 & 1.760 & 0.541 & & & US06 \#2 & 0.064 & 0.055 & 2.491 & 0.994 & \\
\hline & US06 \#3 & 0.041 & 0.035 & 2.364 & 0.543 & & & US06 \#3 & 0.064 & 0.055 & 2.585 & 1.000 & \\
\hline & US06 \#4 & 0.025 & 0.018 & 2.184 & 0.545 & & & US06 \#4 & 0.076 & 0.066 & 2.446 & 1.035 & \\
\hline \multirow[t]{2}{*}{ M85 \#3 } & US06 \#1 & 0.060 & 0.046 & 7.775 & 0.357 & \multirow[t]{2}{*}{2.96} & \multirow[t]{2}{*}{ RFG \#3 } & US06 \#1 & 0.144 & 0.119 & 9.969 & 0.728 & \multirow[t]{2}{*}{3.04} \\
\hline & US06 \#2 & 0.083 & 0.068 & 7.727 & 0.355 & & & US06 \#2 & 0.173 & 0.141 & 11.349 & 0.614 & \\
\hline \multirow[t]{2}{*}{ M85 \#4 } & US06 \#1 & 0.073 & 0.058 & 7.311 & 0.437 & \multirow[t]{2}{*}{1.63} & \multirow[t]{2}{*}{ RFG \#4 } & US06 \#1 & 0.126 & 0.105 & 8.728 & 0.842 & \multirow[t]{2}{*}{4.12} \\
\hline & US06 \#2 & 0.026 & 0.017 & 3.918 & 0.495 & & & US06 \#2 & 0.149 & 0.126 & 9.141 & 0.734 & \\
\hline \multirow[t]{2}{*}{ M85 \#5 } & US06 \#1 & 0.103 & 0.073 & 22.25 & 0.182 & \multirow[t]{2}{*}{7.08} & \multirow[t]{2}{*}{ RFG \#5 } & US06 \#1 & 0.184 & 0.137 & 25.656 & 0.670 & \multirow[t]{2}{*}{8.32} \\
\hline & US06 \#2 & 0.063 & 0.041 & 16.223 & 0.220 & & & US06 \#2 & 0.180 & 0.135 & 25.242 & 0.673 & \\
\hline
\end{tabular}


Appendix C: Emissions Summary of Alcohols, Aldehydes, and Ketones for FTP and US06 
Table C-1. Emissions Summary of Alcohols, Aldehydes, and Ketones for FTP

\begin{tabular}{|c|c|c|c|c|c|c|c|c|c|c|c|c|c|c|c|c|c|c|c|c|}
\hline & \multicolumn{4}{|c|}{ RFG Dodge Caravan \#1 } & \multicolumn{4}{|c|}{ RFG Dodge Caravan \#2 } & \multicolumn{4}{|c|}{ RFG Dodge Caravan \#3 } & \multicolumn{4}{|c|}{ RFG Dodge Caravan \#4 } & \multicolumn{4}{|c|}{ RFG Dodge Caravan \#5 } \\
\hline & $\begin{array}{c}\text { Phase } 1 \\
\mathrm{mg} / \mathrm{mi}\end{array}$ & $\begin{array}{c}\text { Phase } 2 \\
\mathrm{mg} / \mathrm{mi}\end{array}$ & $\begin{array}{c}\text { Phase } 3 \\
\mathrm{mg} / \mathrm{mi}\end{array}$ & $\begin{array}{l}\text { Wghtd } \\
\mathrm{mg} / \mathrm{mi}\end{array}$ & $\begin{array}{c}\text { Phase 1 } \\
\mathrm{mg} / \mathrm{mi}\end{array}$ & $\begin{array}{c}\text { Phase } 2 \\
\mathrm{mg} / \mathrm{mi}\end{array}$ & $\begin{array}{c}\text { Phase } 3 \\
\mathrm{mg} / \mathrm{mi}\end{array}$ & $\begin{array}{l}\text { Wghtd } \\
\mathrm{mg} / \mathrm{mi}\end{array}$ & $\begin{array}{c}\text { Phase } 1 \\
\mathrm{mg} / \mathrm{mi}\end{array}$ & $\begin{array}{c}\text { Phase } 2 \\
\mathrm{mg} / \mathrm{mi}\end{array}$ & $\begin{array}{c}\text { Phase } 3 \\
\mathrm{mg} / \mathrm{mi}\end{array}$ & $\begin{array}{l}\text { Wghtd } \\
\mathrm{mg} / \mathrm{mi}\end{array}$ & $\begin{array}{c}\text { Phase } 1 \\
\mathrm{mg} / \mathrm{mi}\end{array}$ & $\begin{array}{c}\text { Phase } 2 \\
\mathrm{mg} / \mathrm{mi}\end{array}$ & $\begin{array}{c}\text { Phase } 3 \\
\mathrm{mg} / \mathrm{mi}\end{array}$ & $\begin{array}{l}\text { Wghtd } \\
\mathrm{mg} / \mathrm{mi}\end{array}$ & $\begin{array}{c}\text { Phase 1 } \\
\mathrm{mg} / \mathrm{mi}\end{array}$ & $\begin{array}{c}\text { Phase } 2 \\
\mathrm{mg} / \mathrm{mi}\end{array}$ & $\begin{array}{c}\text { Phase } 3 \\
\mathrm{mg} / \mathrm{mi}\end{array}$ & $\begin{array}{l}\text { Wghtd } \\
\mathrm{mg} / \mathrm{mi}\end{array}$ \\
\hline Methanol & 12.42 & 0.00 & 0.00 & 2.59 & 6.77 & 0.00 & 2.71 & 2.15 & 6.50 & 0.00 & 0.00 & 1.35 & 8.31 & 0.00 & 1.22 & 2.06 & 4.66 & 0.00 & 0.00 & 0.96 \\
\hline \multicolumn{21}{|l|}{ Aldehydes } \\
\hline Formaldehyde & 12.46 & 0.00 & 1.54 & 3.02 & 9.50 & 2.38 & 0.35 & 3.32 & 7.31 & 2.88 & 1.65 & 3.47 & 2.38 & 5.27 & 1.12 & 3.54 & 6.74 & 3.45 & 1.36 & 3.63 \\
\hline Acetaldehyde & 5.40 & 0.00 & 1.06 & 1.42 & 4.63 & 0.85 & 0.00 & 1.41 & 2.85 & 0.39 & 1.00 & 1.07 & 0.64 & 0.45 & 0.86 & 0.60 & 5.32 & 0.66 & 1.01 & 1.72 \\
\hline Propionaldehyde & 0.26 & 0.00 & 0.28 & 0.13 & 0.00 & 0.00 & 0.00 & 0.00 & 0.00 & 0.21 & 0.49 & 0.24 & 0.00 & 0.00 & 0.00 & 0.00 & 0.00 & 0.00 & 0.00 & 0.00 \\
\hline Acrolein & 4.33 & 0.00 & 2.66 & 1.63 & 4.31 & 1.70 & 0.00 & 1.78 & 2.09 & 0.51 & 2.35 & 1.35 & 0.19 & 0.33 & 1.81 & 0.71 & 5.60 & 2.02 & 0.39 & 2.32 \\
\hline Methacrolein & 0.00 & 0.03 & 0.00 & 0.00 & 0.00 & 0.00 & 0.00 & 0.00 & 1.76 & 0.00 & 0.00 & 0.37 & 0.52 & 0.00 & 0.00 & 0.11 & 0.00 & 0.00 & 0.00 & 0.00 \\
\hline n-Butyraldehyde & 0.00 & 0.00 & 0.00 & 0.00 & 0.00 & 0.00 & 0.00 & 0.00 & 0.00 & 0.00 & 0.00 & 0.00 & 0.00 & 0.00 & 0.00 & 0.00 & 0.00 & 0.00 & 0.00 & 0.00 \\
\hline Crotonaldehyde & 0.00 & 0.00 & 0.00 & 0.00 & 0.00 & 0.00 & 0.00 & 0.00 & 0.00 & 0.00 & 0.17 & 0.00 & 0.00 & 0.00 & 0.00 & 0.00 & 2.61 & 0.00 & 0.00 & 0.54 \\
\hline Pentanaldehyde & 0.00 & 0.00 & 0.00 & 0.00 & 0.00 & 0.00 & 0.00 & 0.00 & 0.00 & 0.00 & 0.00 & 0.00 & 0.00 & 0.00 & 0.00 & 0.00 & 2.82 & 0.00 & 0.00 & 0.58 \\
\hline Hexanaldehyde & 2.44 & 0.00 & 0.00 & 0.51 & 0.00 & 0.00 & 0.00 & 0.00 & 0.00 & 0.00 & 0.00 & 0.00 & 0.00 & 0.00 & 0.00 & 0.00 & 0.00 & 0.00 & 0.00 & 0.00 \\
\hline \multicolumn{21}{|l|}{$\begin{array}{l}\text { Aromatic } \\
\text { Aldehydes }\end{array}$} \\
\hline Benzaldehyde & 0.00 & 0.00 & 0.00 & 0.00 & 1.81 & 0.00 & 0.00 & 0.38 & 0.00 & 0.28 & 0.00 & 0.14 & 0.44 & 0.00 & 0.00 & 0.09 & 0.00 & 0.00 & 0.00 & 0.00 \\
\hline p-Tolualdehyde & 2.98 & 0.00 & 0.00 & 0.62 & 2.36 & 0.00 & 0.00 & 0.49 & 0.00 & 0.00 & 0.00 & 0.00 & 0.49 & 0.00 & 0.00 & 0.10 & 0.00 & 0.00 & 0.00 & 0.00 \\
\hline \multicolumn{21}{|l|}{ Ketones } \\
\hline Acetone & 0.00 & 0.00 & 0.00 & 0.00 & 0.00 & 0.00 & 0.00 & 0.00 & 0.00 & 0.00 & 0.00 & 0.00 & 0.00 & 0.00 & 0.00 & 0.00 & 0.00 & 0.00 & 0.00 & 0.00 \\
\hline Butanone & 0.00 & 0.00 & 0.00 & 0.00 & 0.00 & 0.00 & 0.00 & 0.00 & 0.00 & 0.00 & 0.00 & 0.00 & 0.00 & 0.00 & 0.00 & 0.00 & 0.00 & 0.00 & 0.00 & 0.00 \\
\hline
\end{tabular}


Table C-1. Emissions Summary of Alcohols, Aldehydes, and Ketones for FTP (continued)

\begin{tabular}{|c|c|c|c|c|c|c|c|c|c|c|c|c|c|c|c|c|c|c|c|c|}
\hline & \multicolumn{4}{|c|}{ RFG Ford Taurus \#1 } & \multicolumn{4}{|c|}{ RFG Ford Taurus \#2 } & \multicolumn{4}{|c|}{ RFG Ford Taurus \#3 } & \multicolumn{4}{|c|}{ RFG Ford Taurus \#4 } & \multicolumn{4}{|c|}{ RFG Ford Taurus \#5 } \\
\hline & $\begin{array}{c}\text { Phase } 1 \\
\mathrm{mg} / \mathrm{mi}\end{array}$ & $\begin{array}{c}\text { Phase } 2 \\
\mathrm{mg} / \mathrm{mi}\end{array}$ & $\begin{array}{c}\text { Phase } 3 \\
\mathrm{mg} / \mathrm{mi}\end{array}$ & $\begin{array}{l}\text { Wghtd } \\
\mathrm{mg} / \mathrm{mi}\end{array}$ & $\begin{array}{c}\text { Phase } 1 \\
\mathrm{mg} / \mathrm{mi}\end{array}$ & $\begin{array}{c}\text { Phase } 2 \\
\mathrm{mg} / \mathrm{mi}\end{array}$ & $\begin{array}{l}\text { Phase } 3 \\
\mathrm{mg} / \mathrm{mi}\end{array}$ & $\begin{array}{l}\text { Wghtd } \\
\mathrm{mg} / \mathrm{mi}\end{array}$ & $\begin{array}{c}\text { Phase } 1 \\
\mathrm{mg} / \mathrm{mi}\end{array}$ & $\begin{array}{c}\text { Phase } 2 \\
\mathrm{mg} / \mathrm{mi}\end{array}$ & $\begin{array}{c}\text { Phase } 3 \\
\mathrm{mg} / \mathrm{mi}\end{array}$ & $\begin{array}{l}\text { Wghtd } \\
\mathrm{mg} / \mathrm{mi}\end{array}$ & $\begin{array}{c}\text { Phase 1 } \\
\mathrm{mg} / \mathrm{mi}\end{array}$ & $\begin{array}{c}\text { Phase } 2 \\
\mathrm{mg} / \mathrm{mi}\end{array}$ & $\begin{array}{c}\text { Phase } 3 \\
\mathrm{mg} / \mathrm{mi}\end{array}$ & $\begin{array}{l}\text { Wghtd } \\
\mathrm{mg} / \mathrm{mi}\end{array}$ & $\begin{array}{c}\text { Phase 1 } \\
\mathrm{mg} / \mathrm{mi}\end{array}$ & $\begin{array}{c}\text { Phase } 2 \\
\mathrm{mg} / \mathrm{mi}\end{array}$ & $\begin{array}{c}\text { Phase } 3 \\
\mathrm{mg} / \mathrm{mi}\end{array}$ & $\begin{array}{l}\text { Wghtd } \\
\mathrm{mg} / \mathrm{mi}\end{array}$ \\
\hline Methanol & 7.35 & 0.00 & 0.00 & 1.52 & 7.05 & 0.00 & 0.00 & 1.45 & 5.44 & 0.00 & 0.00 & 1.12 & 7.38 & 0.00 & 0.00 & 1.52 & 10.89 & 0.00 & 0.00 & 2.25 \\
\hline \multicolumn{21}{|l|}{ Aldehydes } \\
\hline Formaldehyde & 9.14 & 2.69 & 1.26 & 3.63 & 7.59 & 2.01 & 0.91 & 2.86 & 7.80 & 2.80 & 0.77 & 3.28 & 13.28 & 6.99 & 0.95 & 6.64 & 5.99 & 1.80 & 0.54 & 2.32 \\
\hline Acetaldehyde & 2.94 & 0.15 & 1.13 & 0.99 & 1.95 & 0.19 & 0.81 & 0.72 & 2.16 & 0.17 & 0.38 & 0.64 & 2.95 & 0.55 & 0.44 & 1.02 & 1.85 & 0.57 & 0.32 & 0.76 \\
\hline Propionaldehyde & 0.19 & 0.00 & 0.00 & 0.04 & 0.00 & 0.00 & 0.00 & 0.00 & 0.16 & 0.00 & 0.00 & 0.03 & 0.00 & 0.00 & 0.00 & 0.00 & 0.00 & 0.00 & 0.00 & 0.00 \\
\hline Acrolein & 2.88 & 0.41 & 2.08 & 1.38 & 1.98 & 0.19 & 1.21 & 0.84 & 2.50 & 0.74 & 1.38 & 1.28 & 3.14 & 0.96 & 1.57 & 1.58 & 2.30 & 1.00 & 2.31 & 1.63 \\
\hline Methacrolein & 0.00 & 0.00 & 0.00 & 0.00 & 0.00 & 0.00 & 0.00 & 0.00 & 1.33 & 0.00 & 0.00 & 0.28 & 0.60 & 0.00 & 0.17 & 0.17 & 0.00 & 0.00 & 0.00 & 0.00 \\
\hline n-Butyraldehyde & 0.00 & 0.00 & 0.00 & 0.00 & 0.00 & 0.00 & 0.00 & 0.00 & 0.00 & 0.00 & 0.00 & 0.00 & 0.00 & 0.00 & 0.00 & 0.00 & 0.00 & 0.00 & 0.00 & 0.00 \\
\hline Crotonaldehyde & 0.00 & 0.00 & 0.00 & 0.00 & 0.00 & 0.00 & 0.00 & 0.00 & 0.00 & 0.00 & 0.00 & 0.00 & 0.00 & 0.00 & 0.00 & 0.00 & 0.00 & 0.00 & 0.00 & 0.00 \\
\hline Pentanaldehyde & 0.00 & 0.00 & 0.00 & 0.00 & 0.00 & 0.00 & 0.00 & 0.00 & 0.00 & 0.00 & 0.00 & 0.00 & 0.00 & 0.00 & 0.00 & 0.00 & 0.00 & 0.00 & 0.00 & 0.00 \\
\hline Hexanaldehyde & 0.00 & 0.00 & 0.00 & 0.00 & 0.00 & 0.00 & 0.00 & 0.00 & 0.00 & 0.00 & 0.00 & 0.00 & 0.00 & 0.00 & 0.00 & 0.00 & 0.00 & 0.00 & 0.00 & 0.00 \\
\hline \multicolumn{21}{|l|}{$\begin{array}{l}\text { Aromatic } \\
\text { Aldehydes }\end{array}$} \\
\hline Benzaldehyde & 1.00 & 0.00 & 0.00 & 0.21 & 0.46 & 0.00 & 0.00 & 0.10 & 0.54 & 0.00 & 0.00 & 0.11 & 0.77 & 0.00 & 0.00 & 0.16 & 0.50 & 0.00 & 0.00 & 0.10 \\
\hline p-Tolualdehyde & 0.45 & 0.00 & 0.00 & 0.09 & 0.00 & 0.00 & 0.00 & 0.00 & 0.00 & 0.00 & 0.00 & 0.00 & 0.00 & 0.00 & 0.00 & 0.00 & 0.00 & 0.00 & 0.00 & 0.00 \\
\hline \multicolumn{21}{|l|}{ Ketones } \\
\hline Acetone & 0.00 & 0.00 & 0.00 & 0.00 & 0.00 & 0.00 & 0.00 & 0.00 & 0.00 & 0.00 & 0.00 & 0.00 & 0.00 & 0.00 & 0.00 & 0.00 & 0.00 & 0.00 & 0.00 & 0.00 \\
\hline Butanone & 1.08 & 0.00 & 0.00 & 0.22 & 0.60 & 0.00 & 0.00 & 0.12 & 0.00 & 0.00 & 0.00 & 0.00 & 0.00 & 0.00 & 0.00 & 0.00 & 0.55 & 0.00 & 0.00 & 0.11 \\
\hline
\end{tabular}


Table C-1. Emissions Summary of Alcohols, Aldehydes, and Ketones for FTP (concluded)

\begin{tabular}{|c|c|c|c|c|c|c|c|c|c|c|c|c|c|c|c|c|c|c|c|c|}
\hline & $\begin{array}{r}\text { M } \\
\text { Phase } 1 \\
\mathrm{mg} / \mathrm{mi} \\
\end{array}$ & $\begin{array}{c}185 \text { Ford } \\
\text { Phase } 2 \\
\mathrm{mg} / \mathrm{mi}\end{array}$ & $\begin{array}{c}\text { Taurus \# } \\
\text { Phase } 3 \\
\mathrm{mg} / \mathrm{mi} \\
\end{array}$ & $\begin{array}{l}1 \\
\text { Wghtd } \\
\mathrm{mg} / \mathrm{mi}\end{array}$ & $\begin{array}{r}\mathrm{M} \\
\text { Phase } 1 \\
\mathrm{mg} / \mathrm{mi} \\
\end{array}$ & $\begin{array}{c}85 \text { Ford } \\
\text { Phase } 2 \\
\mathrm{mg} / \mathrm{mi}\end{array}$ & $\begin{array}{c}\text { Taurus \# } \\
\text { Phase } 3 \\
\mathrm{mg} / \mathrm{mi}\end{array}$ & $\begin{array}{l}\neq 2 \\
\text { Wghtd } \\
\mathrm{mg} / \mathrm{mi}\end{array}$ & $\begin{array}{r}\text { M } \\
\text { Phase } 1 \\
\text { mg/mi }\end{array}$ & $\begin{array}{c}85 \text { Ford T } \\
\text { Phase } 2 \\
\mathrm{mg} / \mathrm{mi}\end{array}$ & $\begin{array}{c}\text { aurus \#3 } \\
\text { Phase } 3 \\
\mathrm{mg} / \mathrm{mi}\end{array}$ & $\begin{array}{l}\text { Wghtd } \\
\mathrm{mg} / \mathrm{mi}\end{array}$ & $\begin{array}{r}\text { M } \\
\text { Phase } 1 \\
\mathrm{mg} / \mathrm{mi}\end{array}$ & $\begin{array}{c}185 \text { Ford } \\
\text { Phase } 2 \\
\mathrm{mg} / \mathrm{mi}\end{array}$ & $\begin{array}{c}\text { Taurus \# } \\
\text { Phase } 3 \\
\mathrm{mg} / \mathrm{mi}\end{array}$ & $\begin{array}{l}4 \\
\mathrm{Wghtd} \\
\mathrm{mg} / \mathrm{mi}\end{array}$ & $\begin{array}{r}\mathrm{M} \\
\text { Phase } 1 \\
\mathrm{mg} / \mathrm{mi} \\
\end{array}$ & $\begin{array}{c}85 \text { Ford } \\
\text { Phase } 2 \\
\mathrm{mg} / \mathrm{mi}\end{array}$ & $\begin{array}{c}\text { Taurus \# } \\
\text { Phase } 3 \\
\mathrm{mg} / \mathrm{mi} \\
\end{array}$ & $\begin{array}{l}5 \\
\text { Wghtd } \\
\mathrm{mg} / \mathrm{mi} \\
\end{array}$ \\
\hline $\begin{array}{l}\text { Methanol } \\
\text { Aldehydes }\end{array}$ & 825.68 & 1.82 & 51.84 & 185.55 & 777.68 & 0.00 & 10.67 & 164.43 & 1140.05 & 12.32 & 19.93 & 248.08 & 885.48 & 2.44 & 26.06 & 191.16 & 1585.86 & 5.07 & 10.43 & 332.81 \\
\hline Formaldehyde & 49.71 & 11.01 & 2.15 & 16.62 & 43.63 & 9.26 & 1.84 & 14.40 & 55.15 & 12.41 & 2.29 & 18.54 & 54.64 & 12.48 & 2.00 & 18.32 & 103.19 & 13.19 & 1.52 & 28.57 \\
\hline Acetaldehyde & 3.84 & 1.17 & 1.45 & 1.81 & 14.63 & 0.00 & 1.63 & 3.49 & 2.95 & 0.47 & 1.32 & 1.22 & 1.81 & 0.95 & 0.90 & 1.11 & 2.10 & 0.96 & 0.62 & 1.10 \\
\hline $\begin{array}{l}\text { Propionaldehyd } \\
\text { e }\end{array}$ & 1.13 & 0.00 & 0.00 & 0.23 & 2.87 & 0.00 & 0.00 & 0.60 & 1.44 & 1.27 & 0.00 & 0.96 & 0.53 & 0.00 & 0.00 & 0.11 & 0.00 & 0.00 & 0.00 & 0.00 \\
\hline Acrolein & 1.63 & 0.83 & 4.52 & 2.01 & 1.66 & 0.98 & 5.83 & 2.46 & 1.32 & 0.49 & 5.42 & 2.02 & 3.14 & 1.40 & 4.68 & 2.65 & 2.72 & 2.38 & 3.62 & 2.79 \\
\hline Methacrolein & 0.00 & 0.00 & 0.00 & 0.00 & 0.00 & 0.00 & 0.37 & 0.10 & 0.00 & 0.00 & 0.44 & 0.12 & 0.00 & 0.00 & 0.00 & 0.00 & 0.00 & 0.00 & 0.00 & 0.00 \\
\hline $\begin{array}{l}\text { n- } \\
\text { Butyraldehyde }\end{array}$ & 0.00 & 0.00 & 0.00 & 0.00 & 0.00 & 0.00 & 0.00 & 0.00 & 0.00 & 0.00 & 0.00 & 0.00 & 0.00 & 0.00 & 0.00 & 0.00 & 0.00 & 0.00 & 0.00 & 0.00 \\
\hline Crotonaldehyde & 0.00 & 0.00 & 0.00 & 0.00 & 0.00 & 0.00 & 0.00 & 0.00 & 0.00 & 0.00 & 0.00 & 0.00 & 0.00 & 0.00 & 0.00 & 0.00 & 0.00 & 0.00 & 0.00 & 0.00 \\
\hline Pentanaldehyde & 0.00 & 0.00 & 0.00 & 0.00 & 0.00 & 0.00 & 0.00 & 0.00 & 0.00 & 0.00 & 0.00 & 0.00 & 0.00 & 0.00 & 0.00 & 0.00 & 0.00 & 0.00 & 0.00 & 0.00 \\
\hline $\begin{array}{l}\text { Hexanaldehyde } \\
\text { Aromatic } \\
\text { Aldehydes }\end{array}$ & 0.00 & 0.00 & 0.00 & 0.00 & 0.00 & 0.00 & 0.00 & 0.00 & 0.00 & 0.00 & 0.00 & 0.00 & 0.00 & 0.00 & 0.00 & 0.00 & 0.00 & 0.00 & 0.00 & 0.00 \\
\hline Benzaldehyde & 0.00 & 0.00 & 0.00 & 0.00 & 0.00 & 0.00 & 0.00 & 0.00 & 0.00 & 0.00 & 0.00 & 0.00 & 0.00 & 0.00 & 0.00 & 0.00 & 0.00 & 0.00 & 0.35 & 0.10 \\
\hline p-Tolualdehyde & 0.00 & 0.00 & 0.00 & 0.00 & 0.00 & 0.00 & 0.00 & 0.00 & 0.00 & 0.00 & 0.00 & 0.00 & 0.00 & 0.00 & 0.00 & 0.00 & 0.00 & 0.00 & 0.00 & 0.00 \\
\hline & 0.00 & 0.00 & 0.00 & 0.00 & 0.00 & 0.00 & 0.00 & 0.00 & 0.00 & 0.00 & 0.00 & 0.00 & 0.00 & 0.00 & 0.00 & 0.00 & 0.00 & 0.00 & 0.00 & 0.00 \\
\hline Butanone & 0.00 & 0.00 & 0.00 & 0.00 & 0.00 & 0.00 & 0.00 & 0.00 & 0.00 & 0.00 & 0.00 & 0.00 & 0.00 & 0.00 & 0.00 & 0.00 & 0.00 & 0.00 & 0.00 & 0.00 \\
\hline
\end{tabular}


Table C-2. Emissions Summary of Alcohols, Aldehydes, and Ketones for US06

\begin{tabular}{|c|c|c|c|c|c|c|}
\hline & \multicolumn{2}{|c|}{ RFG Dodge Caravans } & \multicolumn{2}{|c|}{ RFG Ford Taurus } & \multicolumn{2}{|c|}{ M85 Ford Taurus } \\
\hline & $\begin{array}{c}\text { Vehicle \#1 } \\
\text { (mg/mi) }\end{array}$ & $\begin{array}{c}\text { Vehicle \#2 } \\
\text { (mg/mi) }\end{array}$ & $\begin{array}{c}\text { Vehicle \#1 } \\
\text { (mg/mi) }\end{array}$ & $\begin{array}{c}\text { Vehicle \#2 } \\
(\mathrm{mg} / \mathrm{mi})\end{array}$ & $\begin{array}{c}\text { Vehicle \#1 } \\
\text { (mg/mi) }\end{array}$ & $\begin{array}{c}\text { Vehicle \#2 } \\
\text { (mg/mi) }\end{array}$ \\
\hline Methanol & 0.00 & 0.00 & 4.00 & 0.00 & 0.00 & 3.00 \\
\hline Aldehydes & & & & & & \\
\hline Formaldehyde & 0.19 & 1.01 & 2.07 & 2.12 & 6.00 & 3.37 \\
\hline Acetaldehyde & 0.20 & 0.64 & 1.00 & 4.16 & 0.00 & 1.86 \\
\hline Propionaldehyde & 0.00 & 0.00 & 0.00 & 0.58 & 5.00 & 0.00 \\
\hline Acrolein & 0.02 & 0.75 & 0.10 & 0.81 & 0.00 & 1.10 \\
\hline Methacrolein & 0.00 & 0.00 & 0.00 & 0.00 & 0.00 & 0.00 \\
\hline n-Butyraldehyde & 0.00 & 0.00 & 0.00 & 0.00 & 0.00 & 0.00 \\
\hline Crotonaldehyde & 0.00 & 0.00 & 0.00 & 0.00 & 0.00 & 0.00 \\
\hline Pentanaldehyde & 0.00 & 0.00 & 0.00 & 0.00 & 0.00 & 0.00 \\
\hline Hexanaldehyde & 0.00 & 0.00 & 0.00 & 0.00 & 0.00 & 0.00 \\
\hline $\begin{array}{l}\text { Aromatic } \\
\text { Aldehdyes }\end{array}$ & & & & & & \\
\hline Benzaldehyde & 0.10 & 0.44 & 0.27 & 0.00 & 0.00 & 0.00 \\
\hline p-Tolualdehyde & 0.00 & 0.00 & 0.14 & 0.00 & 0.00 & 0.00 \\
\hline Ketones & & & & & & \\
\hline Acetone & 0.00 & 0.00 & 0.00 & 0.00 & 0.00 & 0.00 \\
\hline Butanone & 0.08 & 0.00 & 0.00 & 0.00 & 0.00 & 0.00 \\
\hline
\end{tabular}


Appendix D: Particulate Size Distributions 
Table D-1. Particulate Size Distributions (in \% of Total Mass)

Vehicle \# CNG Dodge Caravans over FTP

$\begin{array}{cccc} & <10 \mu \mathrm{m} & <2.5 \mu \mathrm{m} & <1.0 \mu \mathrm{m} \\ 1 & 67.9 \pm 28.9 & 41.1 \pm 31.1 & 17.9 \pm 22.8 \\ 2 & 92.0 \pm 18.6 & 77.0 \pm 23.4 & 64.0 \pm 25.2 \\ 3 & 71.2 \pm 12.9 & 60.6 \pm 16.9 & 44.2 \pm 15.3 \\ 4 & 67.4 \pm 17.6 & 52.2 \pm 18.7 & 34.8 \pm 15.4 \\ 5 & 86.5 \pm 23.7 & 66.2 \pm 24.4 & 48.6 \pm 22.8 \\ \text { Average } & 77.0 & 59.4 & 41.9 \\ \text { St. Dev. } & 11.4 & 13.6 & 17.1\end{array}$

\section{RFG Dodge Caravans over FTP}

1
2
3
4
5

Average

St. Dev.

$\begin{array}{ccc}96.9 \pm 5.9 & 92.6 \pm 8.0 & 87.7 \pm 9.3 \\ 85.1 \pm 7.5 & 59.1 \pm 9.6 & 43.0 \pm 10.1 \\ 92.6 \pm 6.2 & 83.2 \pm 6.9 & 75.2 \pm 8.0 \\ 92.2 \pm 11.9 & 84.4 \pm 13.5 & 77.9 \pm 16.0 \\ 84.7 \pm 12.0 & 72.9 \pm 13.1 & 65.3 \pm 14.6 \\ 90.3 & 78.4 & 69.8 \\ 5.3 & 12.9 & 17.0\end{array}$

FFV Ford Tauruses (M85) over FTP

$\begin{array}{cccc}1 & 69.4 \pm 22.5 & 44.4 \pm 24.0 & 33.3 \pm 19.4 \\ 2 & 81.1 \pm 22.8 & 56.8 \pm 23.4 & 54.1 \pm 24.5 \\ 3 & 80.5 \pm 10.9 & 74.0 \pm 12.4 & 67.5 \pm 14.0 \\ 4 & 100.0 \pm 34.1 & 93.1 \pm 39.0 & 72 . \% \pm 39.6 \\ 5 & 36.2 \pm 13.9 & 25.4 \pm 13.9 & 20.3 \pm 9.3 \\ \text { Average } & 77.0 & 58.4 & 51.6 \\ \text { St. Dev. } & 23.5 & 26.2 & 22.3\end{array}$

FFV Ford Tauruses (RFG) over FTP

$\begin{array}{cccc}1 & 85.0 \pm 14.5 & 61.7 \pm 14.7 & 51.7 \pm 14.6 \\ 2 & 94.4 \pm 13.2 & 87.3 \pm 15.1 & 78.9 \pm 17.5 \\ 3 & 81.6 \pm 17.3 & 63.3 \pm 18.1 & 36.7 \pm 14.8 \\ 4 & 97.0 \pm 9.7 & 79.8 \pm 10.1 & 62.6 \pm 10.2 \\ 5 & 84.5 \pm 6.7 & 83.7 \pm 8.0 & 76.7 \pm 9.4 \\ \text { Average } & 87.0 & 70.8 & 55.8 \\ \text { St. Dev. } & 6.8 & 11.9 & 17.7\end{array}$

Vehicle

CNG Dodge Caravans over US06 \#

$\begin{array}{cccc} & <10.0 \mu \mathrm{m} & <2.5 \mu \mathrm{m} & <1.0 \mu \mathrm{m} \\ 1 & 88.8 \pm 1.4 & 58.0 \pm 1.8 & 46.8 \pm 1.8 \\ 2 & 85.1 \pm 9.0 & 62.9 \pm 11.4 & 39.6 \pm 12.3 \\ 3 & 70.9 \pm 10.3 & 53.8 \pm 10.9 & 24.1 \pm 8.2 \\ 4 & 90.0 \pm 5.3 & 73.2 \pm 5.6 & 58.8 \pm 5.7 \\ 5 & 77.0 \pm 13.6 & 62.3 \pm 14.5 & 41.0 \pm 12.5 \\ \text { Average } & 82.4 & 62.0 & 42.1 \\ \text { St. Dev. } & 8.2 & 7.2 & 12.6\end{array}$

RFG Dodge Caravans over US06

$\begin{array}{ccc}89.5 \pm 1.5 & 63.6 \pm 1.9 & 51.8 \pm 2.0 \\ 86.4 \pm 7.7 & 34.3 \pm 11.7 & 18.6 \pm 12.1 \\ 95.8 \pm 2.2 & 77.0 \pm 2.3 & 56.7 \pm 2.2 \\ 98.6 \pm 3.3 & 79.9 \pm 3.4 & 65.2 \pm 3.5 \\ 87.7 \pm 4.9 & 58.7 \pm 4.9 & 32.4 \pm 3.9 \\ 91.6 & 62.7 & 44.9 \\ 5.3 & 18.2 & 19.0\end{array}$

FFV Ford Tauruses (M85) over US06

$\begin{array}{ccc}78.1 \pm 7.9 & 65.2 \pm 8.5 & 59.0 \pm 9.2 \\ 81.2 \pm 5.9 & 59.7 \pm 7.5 & 50.0 \pm 7.9 \\ 93.5 \pm 20.2 & 79.3 \pm 21.6 & 50.0 \pm 18.6 \\ 50.0 \pm 22.6 & 50.0 \pm 22.6 & 50.0 \pm 22.6 \\ 96.8 \pm 7.7 & 82.0 \pm 8.1 & 66.4 \pm 8.5 \\ 84.3 & 68.1 & 53.0 \\ 18.5 & 13.4 & 7.4\end{array}$

FFV Ford Tauruses (RFG) over US06

$\begin{array}{ccc}91.2 \pm 5.3 & 81.9 \pm 5.9 & 77.2 \pm 7.1 \\ 91.1 \pm 6.3 & 82.9 \pm 8.3 & 76.7 \pm 9.4 \\ \mathrm{NA} & \mathrm{NA} & \mathrm{NA} \\ 92.9 \pm 7.3 & 90.1 \pm 8.7 & 79.4 \pm 9.9 \\ 96.6 \pm 4.1 & 85.6 \pm 4.5 & 78.5 \pm 5.3 \\ 91.2 & 82.4 & 77.0 \\ 2.6 & 3.7 & 1.2\end{array}$

Note: The error bars for individual tests account for only the error in the mass measurements of the impaction substrate, and does not include the error in sample volume measurements or replicate vehicle tests. The mass errors were determined using standard techniques for propagation of errors and the mass measurement precision for single MOUDI substrates developed from replicate weighings of test filters. 


\section{Appendix E: Comparison of PTFE Filter and MOUDI Mass Emission Rates}


Table E-1. Comparison of PTFE Filter and MOUDI Mass Emission Rates

PTFE mass emission rate $\mathrm{mg} / \mathrm{mi}$

CNG Dodge Caravans

\begin{tabular}{|c|c|c|}
\hline FTP \#1 & 0.95 & 0.89 \\
\hline FTP \#2 & 2.29 & 1.94 \\
\hline FTP \#3 & 1.57 & 1.96 \\
\hline FTP \#4 & 1.08 & 1.61 \\
\hline FTP \#5 & 1.01 & 1.25 \\
\hline US06 \#1 & 12.46 & 14.35 \\
\hline US06 \#2 & 5.24 & 4.01 \\
\hline US06 \#3 & 4.74 & 4.68 \\
\hline US06 \#4 & 13.77 & 17.94 \\
\hline US06 \#5 & 2.60 & 3.23 \\
\hline \multicolumn{3}{|c|}{ RFG Dodge Caravans } \\
\hline FTP \#1 & 3.39 & 5.21 \\
\hline FTP \#2 & 0.58 & 1.94 \\
\hline FTP \#3 & 1.83 & 2.04 \\
\hline FTP \#4 & 1.42 & 1.12 \\
\hline FTP \#5 & 1.14 & 0.98 \\
\hline US06 \#1 & 7.99 & 9.60 \\
\hline US06 \#2 & 1.83 & 1.82 \\
\hline US06 \#3 & 11.63 & 12.03 \\
\hline US06 \#4 & 7.95 & 8.53 \\
\hline US06 \#5 & 3.74 & 5.06 \\
\hline \multicolumn{3}{|c|}{ M85 Ford Tauruses } \\
\hline FTP \#1 & 0.35 & 1.12 \\
\hline FTP \#2 & 0.81 & 1.22 \\
\hline FTP \#3 & 0.52 & 2.62 \\
\hline FTP \#4 & 1.56 & 0.88 \\
\hline FTP \#5 & 0.80 & 2.25 \\
\hline US06 \#1 & 2.91 & 2.50 \\
\hline US06 \#2 & 3.50 & 3.95 \\
\hline US06 \#3 & 2.96 & 2.30 \\
\hline US06 \#4 & 1.63 & 1.85 \\
\hline US06 \#5 & 7.08 & 6.20 \\
\hline \multicolumn{3}{|c|}{ RFG Ford Tauruses } \\
\hline FTP \#1 & 0.22 & 0.66 \\
\hline FTP \#2 & 0.63 & 0.92 \\
\hline FTP \#3 & 0.61 & 0.77 \\
\hline FTP \#4 & 1.66 & 1.42 \\
\hline FTP \#5 & 0.46 & 1.91 \\
\hline US06 \#1 & 2.62 & 2.21 \\
\hline US06 \#2 & 2.47 & 1.95 \\
\hline US06 \#3 & 3.04 & N.A. \\
\hline US06 \#4 & 4.12 & 3.57 \\
\hline US06 \#5 & 8.32 & 7.70 \\
\hline
\end{tabular}

$\mathrm{mg} / \mathrm{mi}$

(1)


Appendix F: Chemical Mass Emission Rates for FTP Tests 
Table F-1. Chemical Mass Emission Rates for FTP Tests

Test Type

FTP Weight PM

FTP cumulative PM

Organic Carbon

Elemental Carbon

Total Carbon

$\mathrm{NO}_{3}{ }^{-}$

$\mathrm{SO}_{4}{ }^{2-}$

$\mathrm{Cl}^{-}$

$\mathrm{NH}_{4}^{+}$

$\mathrm{Na}$

$\mathrm{Mg}$

Al

$\mathrm{Si}$

$\mathrm{P}$

$\mathrm{S}$

$\mathrm{Cl}$

$\mathrm{K}$

$\mathrm{Ca}$

$\mathrm{Ti}$

$\mathrm{V}$

$\mathrm{Cr}$

$\mathrm{Mn}$

$\mathrm{Fe}$

Co

$\mathrm{Ni}$

$\mathrm{Cu}$

$\mathrm{Zn}$

$\mathrm{Ga}$

As

$\mathrm{Se}$

$\mathrm{Br}$

$\mathrm{Sr}$

$\mathrm{Y}$

$\mathrm{Zr}$

Mo

$\mathrm{Pd}$

Ag

$\mathrm{Cd}$

In

$\mathrm{Sn}$

$\mathrm{Sb}$

$\mathrm{Ba}$

La

$\mathrm{Au}$

$\mathrm{Hg}$

$\mathrm{Tl}$

$\mathrm{Pb}$

U
CNG Caravan \#1 FTP

$0.96 \mathrm{mg} / \mathrm{mi}$ $0.95 \mathrm{mg} / \mathrm{mi}$

$0.0034+/-0.0956$

$-0.0001+/-0.0324$

$0.0033+/-0.1108$

$-0.0044+/-0.0142$

$0.0182+/-0.0135$

$0.0033+/-0.0130$

$0.0079+/-0.0130$

$-0.0063+/-0.0247$

$0.0045+/-0.0082$

$0.0007+/-0.0036$

$0.0034+/-0.0013$

$0.0012+/-0.0011$

$0.0090+/-0.0012$

$0.0048+/-0.0027$

$0.0028+/-0.0024$

$0.0020+/-0.0017$

$0.0005+/-0.0129$

$0.0002+/-0.0064$

$0.0004+/-0.0019$

$0.0007+/-0.0011$

$0.0441+/-0.0040$

$0.0000+/-0.0008$

$-0.0001+/-0.0006$

$0.0001+/-0.0006$

$0.0067+/-0.0008$

$-0.0002+/-0.0010$

$0.0000+/-0.0012$

$0.0000+/-0.0006$

$-0.0001+/-0.0006$

$-0.0001+/-0.0005$

$0.0000+/-0.0006$

$-0.0001+/-0.0007$

$0.0003+/-0.0008$

$0.0000+/-0.0015$

$0.0015+/-0.0042$

$0.0002+/-0.0050$

$0.0001+/-0.0051$

$-0.0007+/-0.0062$

$0.0000+/-0.0080$

$0.0000+/-0.0092$

$-0.0132+/-0.0340$

$-0.0133+/-0.0452$

$-0.0002+/-0.0017$

$-0.0002+/-0.0014$

$-0.0002+/-0.0013$

$0.0002+/-0.0017$

$0.0000+/-0.0013$
CNG Caravan \#2 FTP

$2.26 \mathrm{mg} / \mathrm{mi}$ $2.29 \mathrm{mg} / \mathrm{mi}$

$0.6870+/-0.1304$

$0.2291+/-0.0327$

$0.9162+/-0.1489$

$0.0942+/-0.0193$

$0.1483+/-0.0216$

$0.0021+/-0.0140$

$0.0493+/-0.0148$

$-0.0009+/-0.0285$

$0.0217+/-0.0088$

$0.0110+/-0.0039$

$0.0294+/-0.0031$

$0.0060+/-0.0014$

$0.0414+/-0.0039$

$0.0105+/-0.0030$

$0.0042+/-0.0022$

$0.0131+/-0.0021$

$0.0019+/-0.0130$

$0.0009+/-0.0059$

$0.0012+/-0.0016$

$0.0009+/-0.0009$

$0.0409+/-0.0037$

$0.0002+/-0.0010$

$0.0006+/-0.0006$

$0.0007+/-0.0006$

$0.0111+/-0.0011$

$0.0001+/-0.0011$

$0.0000+/-0.0012$

$0.0001+/-0.0006$

$0.0001+/-0.0006$

$-0.0001+/-0.0005$

$0.0002+/-0.0006$

$-0.0001+/-0.0007$

$0.0002+/-0.0008$

$0.0002+/-0.0015$

$0.0000+/-0.0044$

$-0.0001+/-0.0051$

$-0.0006+/-0.0052$

$-0.0007+/-0.0064$

$0.0000+/-0.0082$

$0.0005+/-0.0095$

$-0.0110+/-0.0349$

$-0.0133+/-0.0466$

$0.0002+/-0.0018$

$-0.0002+/-0.0014$

$-0.0002+/-0.0013$

$0.0007+/-0.0017$

$0.0001+/-0.0013$
CNG Caravan \#3

FTP

$1.74 \mathrm{mg} / \mathrm{mi}$

$1.57 \mathrm{mg} / \mathrm{mi}$

$0.3212+/-0.1110$

$0.1553+/-0.0288$

$0.4766+/-0.1263$

$0.0356+/-0.0153$

$0.0306+/-0.0141$

$-0.0033+/-0.0134$

$0.0184+/-0.0135$

$0.0030+/-0.0234$

$0.0003+/-0.0082$

$0.0113+/-0.0039$

$0.0179+/-0.0021$

$0.0010+/-0.0011$

$0.0067+/-0.0011$

$0.0025+/-0.0027$

$0.0021+/-0.0021$

$0.0029+/-0.0017$

$0.0010+/-0.0128$

$0.0004+/-0.0058$

$0.0029+/-0.0016$

$0.0006+/-0.0009$

$0.0569+/-0.0051$

$0.0000+/-0.0012$

$0.0013+/-0.0006$

$0.0004+/-0.0006$

$0.0036+/-0.0006$

$-0.0002+/-0.0010$

$0.0000+/-0.0012$

$0.0000+/-0.0006$

$0.0000+/-0.0006$

$-0.0001+/-0.0005$

$0.0002+/-0.0006$

$-0.0001+/-0.0007$

$0.0000+/-0.0008$

$0.0001+/-0.0015$

$0.0018+/-0.0043$

$-0.0012+/-0.0051$

$0.0001+/-0.0052$

$-0.0007+/-0.0063$

$0.0000+/-0.0081$

$0.0012+/-0.0094$

$-0.0132+/-0.0346$

$-0.0133+/-0.0459$

$-0.0001+/-0.0017$

$-0.0002+/-0.0014$

$-0.0002+/-0.0013$

$0.0006+/-0.0017$

$0.0001+/-0.0013$
CNG Caravan \#4

FTP

$1.16 \mathrm{mg} / \mathrm{mi}$

$1.08 \mathrm{mg} / \mathrm{mi}$

$0.2461+/-0.1066$

$0.6768+/-0.0704$

$0.9230+/-0.1473$

$0.0231+/-0.0146$

$0.0179+/-0.0137$

$-0.0036+/-0.0132$

$0.0148+/-0.0132$

$-0.0063+/-0.0243$

$0.0014+/-0.0083$

$0.0021+/-0.0037$

$0.0093+/-0.0015$

$0.0027+/-0.0011$

$0.0168+/-0.0018$

$0.0017+/-0.0027$

$-0.0014+/-0.0027$

$0.0040+/-0.0017$

$0.0005+/-0.0125$

$0.0002+/-0.0057$

$0.0003+/-0.0016$

$0.0002+/-0.0010$

$0.0274+/-0.0025$

$0.0002+/-0.0008$

$-0.0001+/-0.0006$

$0.0004+/-0.0006$

$0.0037+/-0.0006$

$-0.0001+/-0.0010$

$0.0000+/-0.0012$

$0.0000+/-0.0006$

$0.0001+/-0.0006$

$-0.0001+/-0.0005$

$0.0001+/-0.0006$

$0.0000+/-0.0007$

$0.0000+/-0.0008$

$0.0001+/-0.0015$

$0.0000+/-0.0042$

$-0.0012+/-0.0049$

$0.0002+/-0.0050$

$0.0010+/-0.0061$

$0.0014+/-0.0079$

$0.0014+/-0.0091$

$-0.0129+/-0.0335$

$-0.0133+/-0.0446$

$0.0000+/-0.0016$

$-0.0002+/-0.0013$

$-0.0002+/-0.0013$

$0.0007+/-0.0017$

$0.0000+/-0.0012$

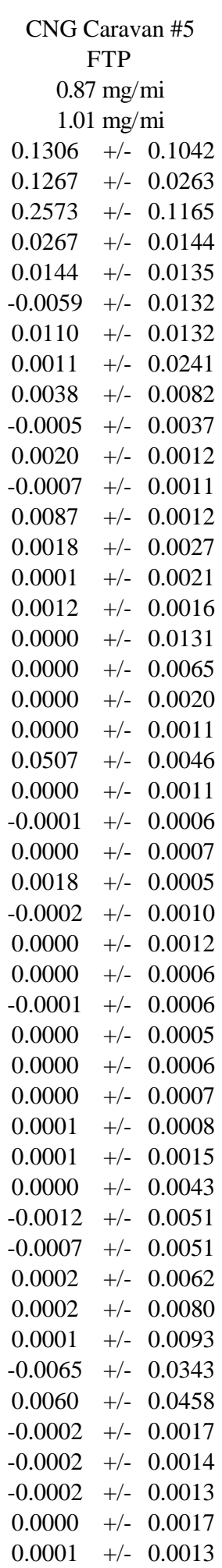




\begin{tabular}{|c|c|}
\hline Test Type & FTP \\
\hline FTP Weight PM & $2.36 \mathrm{mg} / \mathrm{mi}$ \\
\hline FTP cumulative & $3.39 \mathrm{mg} / \mathrm{mi}$ \\
\hline $\mathrm{PM}$ & \\
\hline Organic Carbon & $0.7405+/-0.1307$ \\
\hline Elemental Carbon & $2.5819+/-0.2536$ \\
\hline Total Carbon & $3.3239+/-0.3435$ \\
\hline $\mathrm{NO}_{3}^{-}$ & $0.4612+/-0.1150$ \\
\hline $\mathrm{SO}_{4}^{2-}$ & $0.5380+/-0.1143$ \\
\hline $\mathrm{Cl}^{-}$ & $0.1896+/-0.1050$ \\
\hline $\mathrm{NH}_{4}^{+}$ & $0.1687+/-0.1037$ \\
\hline $\mathrm{Na}$ & $-0.0063+/-0.3191$ \\
\hline $\mathrm{Mg}$ & $0.3882+/-0.0540$ \\
\hline $\mathrm{Al}$ & $0.1791+/-0.0251$ \\
\hline $\mathrm{Si}$ & $0.4193+/-0.0415$ \\
\hline $\mathrm{P}$ & $0.2253+/-0.0235$ \\
\hline$S$ & $0.2658+/-0.0258$ \\
\hline $\mathrm{Cl}$ & $0.1276+/-0.0167$ \\
\hline K & $0.0034+/-0.0336$ \\
\hline $\mathrm{Ca}$ & $0.0947+/-0.0134$ \\
\hline $\mathrm{Ti}$ & $0.0103+/-0.1039$ \\
\hline V & $0.0073+/-0.0409$ \\
\hline $\mathrm{Cr}$ & $0.0000+/-0.0106$ \\
\hline $\mathrm{Mn}$ & $0.0043+/-0.0085$ \\
\hline $\mathrm{Fe}$ & $0.4284+/-0.0388$ \\
\hline Co & $0.0000+/-0.0092$ \\
\hline $\mathrm{Ni}$ & $0.0053+/-0.0058$ \\
\hline $\mathrm{Cu}$ & $0.0523+/-0.0053$ \\
\hline $\mathrm{Zn}$ & $0.3759+/-0.0339$ \\
\hline $\mathrm{Ga}$ & $-0.0002+/-0.0087$ \\
\hline As & $0.0014+/-0.0101$ \\
\hline $\mathrm{Se}$ & $0.0001+/-0.0053$ \\
\hline $\mathrm{Br}$ & $0.0013+/-0.0048$ \\
\hline $\mathrm{Rb}$ & $0.0011+/-0.0044$ \\
\hline $\mathrm{Sr}$ & $0.0000+/-0.0048$ \\
\hline Y & $0.0024+/-0.0060$ \\
\hline $\mathrm{Zr}$ & $0.0024+/-0.0069$ \\
\hline Mo & $0.0037+/-0.0129$ \\
\hline $\mathrm{Pd}$ & $0.0000+/-0.0349$ \\
\hline $\mathrm{Ag}$ & $0.0323+/-0.0424$ \\
\hline $\mathrm{Cd}$ & $0.0025+/-0.0430$ \\
\hline In & $0.0250+/-0.0521$ \\
\hline $\mathrm{Sn}$ & $0.0242+/-0.0677$ \\
\hline $\mathrm{Sb}$ & $0.0445+/-0.0773$ \\
\hline $\mathrm{Ba}$ & $0.0378+/-0.2885$ \\
\hline $\mathrm{La}$ & $0.0377+/-0.3802$ \\
\hline $\mathrm{Au}$ & $-0.0002+/-0.0204$ \\
\hline $\mathrm{Hg}$ & $-0.0002+/-0.0118$ \\
\hline $\mathrm{Tl}$ & $-0.0002+/-0.0111$ \\
\hline $\mathrm{Pb}$ & $0.0047+/-0.0147$ \\
\hline $\mathrm{U}$ & $0.0035+/-0.0107$ \\
\hline
\end{tabular}

Table F-1. Chemical Mass Emission Rates for FTP Tests (continued)

$\begin{array}{ccccc}\text { Table F-1. Chemical Mass Emission Rates for FTP Tests (continued) } & \\ \text { RFG Caravan \#1 } & \text { RFG Caravan \#2 } & \text { RFG Caravan \#3 } & \text { RFG Caravan \#4 } & \text { RFG Caravan \#5 } \\ \text { FTP } & \text { FTP } & \text { FTP } & \text { FTP } & \text { FTP } \\ 2.36 \mathrm{mg} / \mathrm{mi} & 0.44 \mathrm{mg} / \mathrm{mi} & 1.35 \mathrm{mg} / \mathrm{mi} & 1.16 \mathrm{mg} / \mathrm{mi} & 0.92 \mathrm{mg} / \mathrm{mi} \\ 3.39 \mathrm{mg} / \mathrm{mi} & 0.58 \mathrm{mg} / \mathrm{mi} & 1.83 \mathrm{mg} / \mathrm{mi} & 1.42 \mathrm{mg} / \mathrm{mi} & 1.14 \mathrm{mg} / \mathrm{mi}\end{array}$

$-0.1465+/-0.0940$

$0.2865+/-0.0359$

$0.1400+/-0.1057$

$0.0138+/-0.0142$

$0.0317+/-0.0138$

$-0.0100+/-0.0130$

$0.0072+/-0.0130$

$0.0016+/-0.0234$

$0.0006+/-0.0082$

$0.0002+/-0.0036$

$0.0012+/-0.0011$

$0.0003+/-0.0011$

$0.0053+/-0.0010$

$0.0001+/-0.0029$

$-0.0004+/-0.0024$

$0.0008+/-0.0016$

$0.0000+/-0.0126$

$0.0000+/-0.0058$

$0.0000+/-0.0016$

$-0.0001+/-0.0010$

$0.0190+/-0.0018$

$0.0000+/-0.0007$

$-0.0001+/-0.0006$

$0.0000+/-0.0007$

$0.0010+/-0.0005$

$-0.0002+/-0.0010$

$0.0000+/-0.0012$

$0.0000+/-0.0006$

$-0.0001+/-0.0006$

$-0.0001+/-0.0005$

$0.0000+/-0.0006$

$0.0000+/-0.0007$

$0.0000+/-0.0008$

$0.0000+/-0.0015$

$0.0000+/-0.0042$

$-0.0010+/-0.0050$

$0.0008+/-0.0051$

$-0.0003+/-0.0062$

$0.0005+/-0.0079$

$0.0014+/-0.0092$

$-0.0132+/-0.0339$

$-0.0133+/-0.0452$

$-0.0002+/-0.0016$

$-0.0002+/-0.0014$

$-0.0002+/-0.0013$

$0.0000+/-0.0017$

$0.0000+/-0.0013$

\begin{abstract}
$0.2978+/-0.1019$
$1.1033+/-0.1104$

$1.4011+/-0.1752$

$-0.0034+/-0.0139$

$-0.0104+/-0.0132$

$-0.0050+/-0.0130$

$0.0043+/-0.0129$

$-0.0063+/-0.0249$

$0.0021+/-0.0083$

$0.0002+/-0.0036$

$0.0115+/-0.0016$

$0.0062+/-0.0013$

$0.0121+/-0.0014$

$0.0057+/-0.0028$

$-0.0009+/-0.0026$

$0.0158+/-0.0022$

$0.0008+/-0.0125$

$0.0002+/-0.0057$

$0.0004+/-0.0016$

$0.0003+/-0.0010$

$0.0211+/-0.0020$

$0.0000+/-0.0007$

$0.0000+/-0.0006$

$0.0010+/-0.0006$

$0.0081+/-0.0009$

$-0.0002+/-0.0010$

$0.0000+/-0.0012$

$0.0000+/-0.0006$

$0.0000+/-0.0006$

$-0.0001+/-0.0005$

$0.0000+/-0.0006$

$0.0000+/-0.0007$

$0.0000+/-0.0008$

$0.0000+/-0.0015$

$0.0006+/-0.0042$

$0.0001+/-0.0049$

$0.0003+/-0.0050$

$0.0005+/-0.0061$

$0.0001+/-0.0079$

$0.0000+/-0.0091$

$-0.0132+/-0.0334$

$-0.0129+/-0.0445$

$-0.0002+/-0.0017$

$-0.0002+/-0.0013$

$-0.0002+/-0.0013$

$0.0002+/-0.0017$

$0.0000+/-0.0012$
\end{abstract}

$0.1021+/-0.0960$

$0.5760+/-0.0609$

$0.6781+/-0.1263$

$0.0193+/-0.0143$

$0.0190+/-0.0135$

$-0.0071+/-0.0130$

$0.0214+/-0.0132$

$-0.0063+/-0.0247$

$0.0061+/-0.0082$

$0.0040+/-0.0036$

$0.0016+/-0.0012$

$0.0077+/-0.0013$

$0.0079+/-0.0012$

$0.0024+/-0.0027$

$-0.0008+/-0.0024$

$0.0122+/-0.0020$

$0.0000+/-0.0129$

$0.0000+/-0.0064$

$0.0000+/-0.0019$

$0.0001+/-0.0011$

$0.0291+/-0.0027$

$0.0000+/-0.0008$

$0.0000+/-0.0006$

$0.0005+/-0.0006$

$0.0118+/-0.0012$

$-0.0002+/-0.0010$

$0.0001+/-0.0012$

$0.0000+/-0.0006$

$0.0000+/-0.0006$

$0.0000+/-0.0005$

$0.0000+/-0.0006$

$-0.0001+/-0.0007$

$0.0002+/-0.0008$

$0.0000+/-0.0015$

$0.0013+/-0.0042$

$-0.0002+/-0.0050$

$-0.0004+/-0.0051$

$-0.0007+/-0.0062$

$0.0009+/-0.0080$

$0.0000+/-0.0092$

$-0.0096+/-0.0340$

$-0.0011+/-0.0452$

$-0.0002+/-0.0017$

$-0.0002+/-0.0014$

$-0.0002+/-0.0013$

$0.0000+/-0.0017$

$0.0000+/-0.0013$
$-0.0564+/-0.0939$

$0.4512+/-0.0497$

$0.3948+/-0.1131$

$-0.0135+/-0.0139$

$0.0027+/-0.0133$

$-0.0068+/-0.0130$

$0.0037+/-0.0130$

$-0.0063+/-0.0232$

$0.0022+/-0.0082$

$0.0045+/-0.0036$

$0.0004+/-0.0012$

$0.0045+/-0.0011$

$0.0011+/-0.0009$

$0.0024+/-0.0027$

$-0.0006+/-0.0023$

$0.0067+/-0.0017$

$0.0011+/-0.0123$

$0.0004+/-0.0057$

$0.0006+/-0.0015$

$0.0004+/-0.0009$

$0.0376+/-0.0034$

$0.0000+/-0.0009$

$0.0001+/-0.0006$

$0.0007+/-0.0006$

$0.0051+/-0.0007$

$-0.0001+/-0.0010$

$0.0000+/-0.0011$

$0.0000+/-0.0006$

$-0.0001+/-0.0006$

$-0.0001+/-0.0005$

$0.0001+/-0.0005$

$-0.0001+/-0.0007$

$0.0000+/-0.0008$

$0.0000+/-0.0015$

$0.0006+/-0.0041$

$0.0002+/-0.0049$

$-0.0007+/-0.0050$

$-0.0007+/-0.0060$

$0.0000+/-0.0078$

$0.0000+/-0.0090$

$-0.0132+/-0.0330$

$-0.0126+/-0.0439$

$-0.0001+/-0.0016$

$-0.0002+/-0.0013$

$-0.0002+/-0.0012$

$0.0002+/-0.0016$

$0.0000+/-0.0012$ 


\begin{tabular}{|c|c|}
\hline Test Type & $\begin{array}{l}\text { M85 Taurus \#1 } \\
\text { FTP }\end{array}$ \\
\hline FTP Weight PM & $0.26 \mathrm{mg} / \mathrm{mi}$ \\
\hline FTP cumulative & $0.35 \mathrm{mg} / \mathrm{mi}$ \\
\hline $\mathrm{PM}$ & \\
\hline Organic Carbon & $0.0536+/-0.1062$ \\
\hline Elemental Carbon & $0.0678+/-0.0238$ \\
\hline Total Carbon & $0.1214+/-0.1147$ \\
\hline $\mathrm{NO}_{3}^{-}$ & $0.0066+/-0.0154$ \\
\hline $\mathrm{SO}_{4}^{2-}$ & $0.0374+/-0.0154$ \\
\hline $\mathrm{Cl}^{-}$ & $-0.0056+/-0.0146$ \\
\hline $\mathrm{NH}_{4}^{+}$ & $0.0118+/-0.0148$ \\
\hline $\mathrm{Na}$ & $0.0104+/-0.0209$ \\
\hline $\mathrm{Mg}$ & $-0.0049+/-0.0108$ \\
\hline $\mathrm{Al}$ & $-0.0037+/-0.0054$ \\
\hline $\mathrm{Si}$ & $0.0048+/-0.0014$ \\
\hline $\mathrm{P}$ & $0.0066+/-0.0013$ \\
\hline$S$ & $0.0103+/-0.0014$ \\
\hline $\mathrm{Cl}$ & $0.0035+/-0.0028$ \\
\hline $\mathrm{K}$ & $-0.0006+/-0.0026$ \\
\hline $\mathrm{Ca}$ & $0.0141+/-0.0022$ \\
\hline $\mathrm{Ti}$ & $0.0018+/-0.0138$ \\
\hline V & $0.0000+/-0.0070$ \\
\hline $\mathrm{Cr}$ & $0.0001+/-0.0021$ \\
\hline $\mathrm{Mn}$ & $-0.0001+/-0.0012$ \\
\hline $\mathrm{Fe}$ & $0.0291+/-0.0027$ \\
\hline Co & $0.0004+/-0.0009$ \\
\hline $\mathrm{Ni}$ & $0.0004+/-0.0006$ \\
\hline $\mathrm{Cu}$ & $0.0004+/-0.0006$ \\
\hline $\mathrm{Zn}$ & $0.0055+/-0.0007$ \\
\hline $\mathrm{Ga}$ & $0.0000+/-0.0011$ \\
\hline As & $0.0001+/-0.0012$ \\
\hline $\mathrm{Se}$ & $0.0001+/-0.0006$ \\
\hline $\mathrm{Br}$ & $0.0001+/-0.0006$ \\
\hline $\mathrm{Rb}$ & $0.0000+/-0.0005$ \\
\hline $\mathrm{Sr}$ & $0.0001+/-0.0006$ \\
\hline Y & $0.0000+/-0.0007$ \\
\hline $\mathrm{Zr}$ & $0.0000+/-0.0008$ \\
\hline Mo & $0.0005+/-0.0016$ \\
\hline $\mathrm{Pd}$ & $0.0000+/-0.0045$ \\
\hline $\mathrm{Ag}$ & $-0.0012+/-0.0053$ \\
\hline $\mathrm{Cd}$ & $-0.0007+/-0.0054$ \\
\hline In & $-0.0007+/-0.0066$ \\
\hline $\mathrm{Sn}$ & $0.0018+/-0.0084$ \\
\hline $\mathrm{Sb}$ & $0.0002+/-0.0097$ \\
\hline $\mathrm{Ba}$ & $-0.0132+/-0.0362$ \\
\hline $\mathrm{La}$ & $-0.0025+/-0.0478$ \\
\hline $\mathrm{Au}$ & $-0.0002+/-0.0017$ \\
\hline $\mathrm{Hg}$ & $-0.0002+/-0.0014$ \\
\hline $\mathrm{Tl}$ & $-0.0001+/-0.0013$ \\
\hline $\mathrm{Pb}$ & $0.0005+/-0.0018$ \\
\hline $\mathrm{U}$ & $0.0002+/-0.0013$ \\
\hline
\end{tabular}

\section{Table F-1. Chemical Mass Emission Rates for FTP (continued)}

$\begin{array}{cc}\text { M85 Taurus \#2 } & \text { M85 Taurus \#3 } \\ \text { FTP } & \text { FTP } \\ 0.75 \mathrm{mg} / \mathrm{mi} & 0.47 \mathrm{mg} / \mathrm{mi} \\ 0.81 \mathrm{mg} / \mathrm{mi} & 0.52 \mathrm{mg} / \mathrm{mi}\end{array}$

$0.1813+/-0.1110$

$0.1255+/-0.0256$

$0.3068+/-0.1191$

$-0.0078+/-0.0141$

$0.0228+/-0.0138$

$-0.0022+/-0.0132$

$0.0120+/-0.0136$

$0.0065+/-0.0250$

$-0.0022+/-0.0101$

$-0.0025+/-0.0048$

$-0.0003+/-0.0012$

$0.0056+/-0.0012$

$0.0110+/-0.0014$

$0.0115+/-0.0029$

$0.0014+/-0.0021$

$0.0187+/-0.0024$

$0.0001+/-0.0130$

$0.0000+/-0.0064$

$0.0056+/-0.0017$

$0.0001+/-0.0011$

$0.0312+/-0.0029$

$0.0003+/-0.0009$

$0.0018+/-0.0006$

$0.0015+/-0.0006$

$0.0058+/-0.0007$

$-0.0002+/-0.0010$

$0.0000+/-0.0012$

$0.0000+/-0.0006$

$-0.0001+/-0.0006$

$-0.0001+/-0.0005$

$0.0002+/-0.0006$

$-0.0001+/-0.0007$

$0.0003+/-0.0008$

$0.0004+/-0.0015$

$0.0000+/-0.0043$

$-0.0012+/-0.0050$

$-0.0007+/-0.0051$

$-0.0007+/-0.0063$

$0.0000+/-0.0080$

$0.0010+/-0.0093$

$-0.0115+/-0.0342$

$-0.0016+/-0.0454$

$-0.0002+/-0.0017$

$-0.0002+/-0.0014$

$-0.0002+/-0.0013$

$0.0009+/-0.0015$

$0.0000+/-0.0013$
$-0.1139+/-0.1037$

$-0.0048+/-0.0231$

$-0.1170+/-0.1128$

$0.0036+/-0.0141$

$0.0175+/-0.0137$

$0.0025+/-0.0133$

$0.0218+/-0.0141$

$0.0095+/-0.0209$

$0.0025+/-0.0082$

$-0.0007+/-0.0047$

$0.0019+/-0.0013$

$0.0040+/-0.0012$

$0.0174+/-0.0018$

$0.0136+/-0.0030$

$0.0005+/-0.0021$

$0.0098+/-0.0019$

$0.0007+/-0.0128$

$0.0000+/-0.0063$

$0.0000+/-0.0019$

$0.0034+/-0.0010$

$0.0346+/-0.0032$

$0.0002+/-0.0009$

$0.0000+/-0.0006$

$0.0035+/-0.0007$

$0.0094+/-0.0010$

$-0.0002+/-0.0010$

$0.0001+/-0.0012$

$0.0000+/-0.0006$

$0.0000+/-0.0006$

$-0.0001+/-0.0005$

$0.0001+/-0.0006$

$-0.0001+/-0.0007$

$0.0005+/-0.0007$

$0.0000+/-0.0015$

$0.0003+/-0.0042$

$-0.0005+/-0.0049$

$-0.0007+/-0.0050$

$-0.0007+/-0.0061$

$0.0004+/-0.0079$

$0.0005+/-0.0091$

$-0.0132+/-0.0336$

$-0.0018+/-0.0446$

$-0.0002+/-0.0017$

$-0.0002+/-0.0013$

$-0.0002+/-0.0013$

$0.0004+/-0.0017$

$0.0000+/-0.0012$
M85 Taurus \#4

FTP

$1.32 \mathrm{mg} / \mathrm{mi}$

$1.56 \mathrm{mg} / \mathrm{mi}$

$0.0848+/-0.1075$

$0.0754+/-0.0240$

$0.1602+/-0.1153$

$0.0175+/-0.0144$

$0.0083+/-0.0135$

$-0.0073+/-0.0132$

$0.0037+/-0.0133$

$0.0104+/-0.0207$

$-0.0025+/-0.0102$

$-0.0014+/-0.0050$

$0.0050+/-0.0014$

$0.0074+/-0.0013$

$0.0097+/-0.0013$

$0.0036+/-0.0027$

$0.0019+/-0.0021$

$0.0186+/-0.0024$

$0.0019+/-0.0127$

$0.0003+/-0.0058$

$0.0005+/-0.0016$

$-0.0001+/-0.0010$

$0.0188+/-0.0018$

$0.0003+/-0.0007$

$0.0001+/-0.0006$

$0.0026+/-0.0006$

$0.0098+/-0.0010$

$-0.0002+/-0.0010$

$0.0000+/-0.0012$

$0.0001+/-0.0006$

$0.0000+/-0.0006$

$0.0000+/-0.0005$

$0.0003+/-0.0005$

$-0.0001+/-0.0007$

$0.0004+/-0.0007$

$0.0000+/-0.0015$

$0.0001+/-0.0050$

$-0.0003+/-0.0051$

$-0.0007+/-0.0062$

$0.0011+/-0.0080$

$0.0001+/-0.0092$

$-0.0132+/-0.0340$

$-0.0123+/-0.0452$

$-0.0002+/-0.0017$

$-0.0002+/-0.0014$

$-0.0002+/-0.0013$

$0.0005+/-0.0017$

$0.0001+/-0.0012$
$0.0000+/-0.0043$

\section{M85 Taurus \#5 FTP \\ $0.71 \mathrm{mg} / \mathrm{mi}$ \\ $0.80 \mathrm{mg} / \mathrm{mi}$}

$-0.0156+/-0.1053$

$0.0045+/-0.0231$

$-0.0111+/-0.1135$

$-0.0088+/-0.0141$

$-0.0217+/-0.0135$

$-0.0048+/-0.0132$

$-0.0116+/-0.0131$

$0.0139+/-0.0203$

$-0.0016+/-0.0081$

$-0.0021+/-0.0043$

$-0.0015+/-0.0011$

$-0.0005+/-0.0010$

$-0.0050+/-0.0009$

$0.0008+/-0.0030$

$0.0000+/-0.0021$

$0.0024+/-0.0016$

$0.0002+/-0.0126$

$0.0000+/-0.0061$

$0.0006+/-0.0018$

$0.0000+/-0.0010$

$0.0149+/-0.0014$

$0.0000+/-0.0007$

$0.0002+/-0.0006$

$0.0019+/-0.0006$

$0.0025+/-0.0006$

$0.0000+/-0.0010$

$0.0000+/-0.0011$

$0.0001+/-0.0006$

$0.0000+/-0.0006$

$-0.0001+/-0.0005$

$0.0001+/-0.0005$

$0.0000+/-0.0007$

$0.0002+/-0.0008$

$0.0002+/-0.0014$

$0.0004+/-0.0042$

$-0.0004+/-0.0049$

$0.0004+/-0.0050$

$-0.0007+/-0.0060$

$0.0015+/-0.0078$

$0.0019+/-0.0090$

$-0.0132+/-0.0331$

$-0.0040+/-0.0441$

$0.0002+/-0.0016$

$-0.0002+/-0.0013$

$-0.0002+/-0.0012$

$0.0008+/-0.0015$

$0.0000+/-0.0012$ 


\section{Table F-1. Chemical Mass Emission Rates for FTP Tests (concluded)}

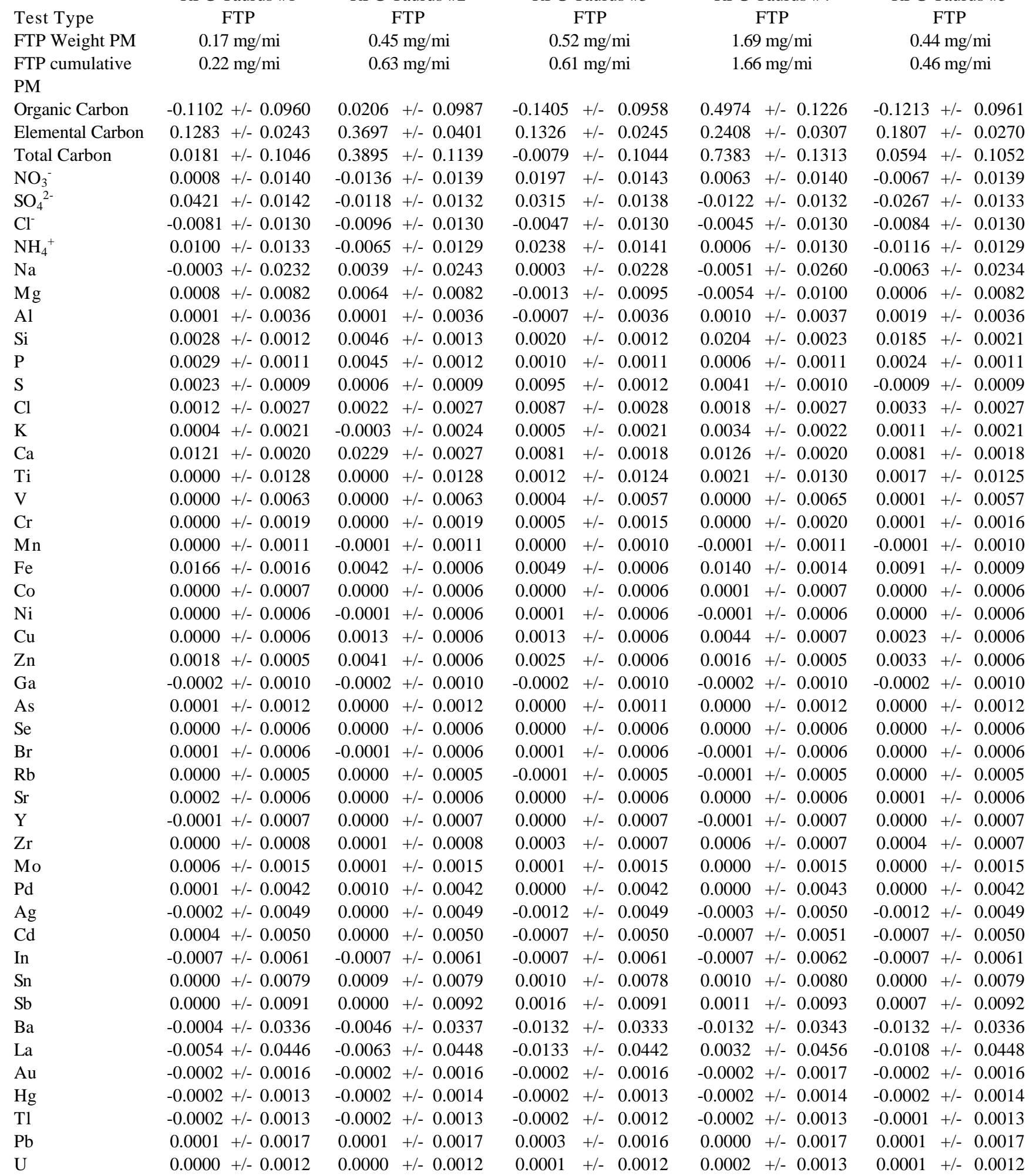


Appendix G: Chemical Mass Emission Rates for US06 Tests 
Table G-1. Chemical Mass Emission Rates for US06 Tests

\begin{tabular}{|c|c|c|c|c|c|c|c|c|c|c|c|}
\hline \multirow{3}{*}{$\begin{array}{l}\text { Test Type } \\
\text { US06 PM } \\
\text { Organic Carbon }\end{array}$} & \multicolumn{3}{|c|}{$\begin{array}{c}\text { CNG Caravan \#1 } \\
\text { US06 }\end{array}$} & \multicolumn{2}{|c|}{$\begin{array}{c}\text { CNG Caravan \#2 } \\
\text { US06 }\end{array}$} & \multicolumn{3}{|c|}{$\begin{array}{c}\text { RFG Caravan \# } 1 \\
\text { US06 }\end{array}$} & \multicolumn{3}{|c|}{$\begin{array}{c}\text { RFG Caravan \#2 } \\
\text { US06 }\end{array}$} \\
\hline & 12.4 & $\mathrm{mg} /$ & & & $\mathrm{mg} / \mathrm{mi}$ & 7.9 & $\mathrm{mg} /$ & & & $3 \mathrm{mg}$ & \\
\hline & 6.7041 & $+/-$ & 0.6865 & 1.7299 & $+/-0.2085$ & 1.2955 & $+/-$ & 0.1684 & 0.6078 & $+/-$ & 0.1174 \\
\hline Elemental Carbon & 1.6487 & $+/-$ & 0.1632 & 0.9894 & +/- 0.0997 & 3.6341 & $+/-$ & 0.3558 & 0.3236 & $+/-$ & 0.0386 \\
\hline Total Carbon & 8.3528 & $+/-$ & 0.8129 & 2.7194 & $+/-0.2890$ & 4.9296 & $+/-$ & 0.4897 & 0.9314 & $+/-$ & 0.1413 \\
\hline $\mathrm{NO}_{3}^{-}$ & 0.0323 & $+/-$ & 0.0141 & 0.0493 & $+/-0.0151$ & -0.0033 & $+/-$ & 0.0134 & 0.1428 & $+/-$ & 0.0376 \\
\hline $\mathrm{SO}_{4}{ }^{2-}$ & 0.0390 & $+/-$ & 0.0134 & 0.0444 & $+/-0.0136$ & 0.0397 & $+/-$ & 0.0134 & 0.2706 & $+/-$ & 0.0431 \\
\hline $\mathrm{Cl}^{-}$ & -0.0011 & $+/-$ & 0.0123 & -0.0023 & $+/-0.0126$ & 0.0139 & $+/-$ & 0.0127 & 0.0603 & $+/-$ & 0.0342 \\
\hline $\mathrm{NH}_{4}^{+}$ & 0.0697 & $+/-$ & 0.0142 & 0.0305 & $+/-0.0129$ & 0.0225 & $+/-$ & 0.0126 & 0.1337 & $+/-$ & 0.0358 \\
\hline $\mathrm{Na}$ & -0.0063 & $+/-$ & 0.0267 & -0.0063 & $+/-0.0300$ & -0.0063 & $+/-$ & 0.0425 & -0.0063 & $+/-$ & 0.1039 \\
\hline $\mathrm{Mg}$ & 0.0389 & $+/-$ & 0.0092 & 0.0357 & +/- 0.0092 & 0.0810 & $+/-$ & 0.0114 & 0.1421 & $+/-$ & 0.0205 \\
\hline $\mathrm{Al}$ & 0.0830 & $+/-$ & 0.0085 & 0.0409 & $+/-0.0054$ & 0.0050 & $+/-$ & 0.0038 & 0.0650 & $+/-$ & 0.0109 \\
\hline $\mathrm{Si}$ & 0.4903 & $+/-$ & 0.0439 & 0.1800 & $+/-0.0162$ & 0.0549 & $+/-$ & 0.0052 & 0.2196 & $+/-$ & 0.0210 \\
\hline$P$ & 0.0132 & $+/-$ & 0.0017 & 0.0280 & $+/-0.0028$ & 0.0748 & $+/-$ & 0.0069 & 0.1419 & $+/-$ & 0.0136 \\
\hline S & 0.0740 & $+/-$ & 0.0067 & 0.0474 & $+/-0.0044$ & 0.0604 & $+/-$ & 0.0055 & 0.1863 & $+/-$ & 0.0172 \\
\hline $\mathrm{Cl}$ & 0.0273 & $+/-$ & 0.0037 & 0.0149 & $+/-0.0031$ & 0.0469 & $+/-$ & 0.0051 & 0.0546 & $+/-$ & 0.0070 \\
\hline K & 0.0294 & $+/-$ & 0.0034 & 0.0095 & $+/-0.0023$ & 0.0003 & $+/-$ & 0.0021 & 0.0069 & $+/-$ & 0.0032 \\
\hline $\mathrm{Ca}$ & 0.0150 & $+/-$ & 0.0021 & 0.0257 & $+/-0.0028$ & 0.0305 & $+/-$ & 0.0032 & 0.1706 & $+/-$ & 0.0159 \\
\hline $\mathrm{Ti}$ & 0.0072 & $+/-$ & 0.0116 & 0.0017 & $+/-0.0121$ & 0.0008 & $+/-$ & 0.0120 & 0.0000 & $+/-$ & 0.0312 \\
\hline V & 0.0023 & $+/-$ & 0.0054 & 0.0004 & $+/-0.0056$ & 0.0004 & $+/-$ & 0.0056 & 0.0000 & $+/-$ & 0.0126 \\
\hline $\mathrm{Cr}$ & 0.0126 & $+/-$ & 0.0019 & 0.0038 & $+/-0.0016$ & 0.0020 & $+/-$ & 0.0016 & 0.0107 & $+/-$ & 0.0022 \\
\hline $\mathrm{Mn}$ & 0.0020 & $+/-$ & 0.0010 & 0.0008 & $+/-0.0009$ & 0.0009 & $+/-$ & 0.0009 & 0.0041 & $+/-$ & 0.0014 \\
\hline $\mathrm{Fe}$ & 0.2169 & $+/-$ & 0.0194 & 0.0948 & $+/-0.0085$ & 0.0725 & $+/-$ & 0.0065 & 0.6838 & $+/-$ & 0.0613 \\
\hline Co & 0.0000 & $+/-$ & 0.0035 & 0.0000 & $+/-0.0017$ & 0.0000 & $+/-$ & 0.0014 & 0.0000 & $+/-$ & 0.0112 \\
\hline $\mathrm{Ni}$ & 0.0040 & $+/-$ & 0.0007 & 0.0029 & $+/-0.0006$ & 0.0036 & $+/-$ & 0.0007 & 0.0091 & $+/-$ & 0.0012 \\
\hline $\mathrm{Cu}$ & 0.0020 & $+/-$ & 0.0006 & 0.0018 & $+/-0.0006$ & 0.0187 & $+/-$ & 0.0018 & 0.0192 & $+/-$ & 0.0020 \\
\hline $\mathrm{Zn}$ & 0.0206 & $+/-$ & 0.0019 & 0.0434 & $+/-0.0039$ & 0.1281 & $+/-$ & 0.0115 & 0.1924 & $+/-$ & 0.0173 \\
\hline $\mathrm{Ga}$ & -0.0002 & $+/-$ & 0.0010 & -0.0002 & $+/-\quad 0.0010$ & -0.0002 & $+/-$ & 0.0010 & -0.0002 & $+/-$ & 0.0026 \\
\hline As & 0.0000 & $+/-$ & 0.0011 & 0.0000 & $+/-0.0011$ & 0.0000 & $+/-$ & 0.0012 & 0.0000 & $+/-$ & 0.0035 \\
\hline $\mathrm{Se}$ & 0.0000 & $+/-$ & 0.0006 & 0.0000 & $+/-0.0006$ & 0.0000 & $+/-$ & 0.0006 & 0.0000 & $+/-$ & 0.0015 \\
\hline $\mathrm{Br}$ & 0.0007 & $+/-$ & 0.0005 & 0.0008 & $+/-0.0005$ & 0.0004 & $+/-$ & 0.0005 & 0.0033 & $+/-$ & 0.0008 \\
\hline $\mathrm{Rb}$ & 0.0001 & $+/-$ & 0.0005 & 0.0001 & $+/-0.0005$ & -0.0001 & $+/-$ & 0.0005 & -0.0001 & $+/-$ & 0.0013 \\
\hline $\mathrm{Sr}$ & 0.0001 & $+/-$ & 0.0005 & 0.0002 & $+/-0.0005$ & 0.0001 & $+/-$ & 0.0005 & 0.0001 & $+/-$ & 0.0014 \\
\hline $\mathrm{Y}$ & -0.0001 & $+/-$ & 0.0007 & -0.0001 & $+/-0.0007$ & -0.0001 & $+/-$ & 0.0007 & 0.0002 & $+/-$ & 0.0017 \\
\hline $\mathrm{Zr}$ & 0.0031 & $+/-$ & 0.0008 & 0.0010 & $+/-0.0007$ & 0.0001 & $+/-$ & 0.0008 & 0.0011 & $+/-$ & 0.0020 \\
\hline Mo & 0.0008 & $+/-$ & 0.0014 & 0.0004 & $+/-\quad 0.0014$ & 0.0008 & $+/-$ & 0.0014 & 0.0015 & $+/-$ & 0.0037 \\
\hline $\mathrm{Pd}$ & 0.0033 & $+/-$ & 0.0039 & 0.0000 & $+/-0.0041$ & 0.0005 & $+/-$ & 0.0040 & 0.0000 & $+/-$ & 0.0106 \\
\hline $\mathrm{Ag}$ & -0.0012 & $+/-$ & 0.0046 & -0.0012 & +/- 0.0048 & -0.0009 & $+/-$ & 0.0047 & 0.0024 & $+/-$ & 0.0123 \\
\hline $\mathrm{Cd}$ & -0.0006 & $+/-$ & 0.0047 & -0.0007 & $+/-\quad 0.0049$ & 0.0001 & $+/-$ & 0.0048 & 0.0004 & $+/-$ & 0.0126 \\
\hline In & -0.0007 & $+/-$ & 0.0058 & -0.0007 & $+/-0.0059$ & -0.0007 & $+/-$ & 0.0058 & 0.0019 & $+/-$ & 0.0150 \\
\hline $\mathrm{Sn}$ & 0.0005 & $+/-$ & 0.0074 & 0.0008 & $+/-0.0076$ & 0.0006 & $+/-$ & 0.0076 & 0.0105 & $+/-$ & 0.0195 \\
\hline $\mathrm{Sb}$ & 0.0005 & $+/-$ & 0.0086 & 0.0014 & $+/-0.0088$ & 0.0024 & $+/-$ & 0.0087 & 0.0056 & $+/-$ & 0.0216 \\
\hline $\mathrm{Ba}$ & -0.0082 & $+/-$ & 0.0316 & -0.0074 & +/- 0.0323 & -0.0132 & $+/-$ & 0.0321 & 0.0422 & $+/-$ & 0.0845 \\
\hline $\mathrm{La}$ & -0.0133 & $+/-$ & 0.0421 & -0.0133 & +/- 0.0431 & -0.0133 & $+/-$ & 0.0427 & -0.0133 & $+/-$ & 0.1093 \\
\hline $\mathrm{Au}$ & 0.0000 & $+/-$ & 0.0018 & -0.0001 & $+/-0.0024$ & -0.0002 & $+/-$ & 0.0049 & 0.0006 & $+/-$ & 0.0086 \\
\hline $\mathrm{Hg}$ & -0.0002 & $+/-$ & 0.0013 & -0.0002 & +/- 0.0013 & -0.0002 & $+/-$ & 0.0014 & -0.0002 & $+/-$ & 0.0035 \\
\hline $\mathrm{Tl}$ & -0.0002 & $+/-$ & 0.0012 & -0.0002 & $+/-0.0012$ & -0.0002 & $+/-$ & 0.0012 & -0.0002 & $+/-$ & 0.0031 \\
\hline $\mathrm{Pb}$ & 0.0006 & $+/-$ & 0.0015 & 0.0007 & $+/-0.0015$ & 0.0018 & $+/-$ & 0.0015 & 0.0105 & $+/-$ & 0.0023 \\
\hline $\mathrm{U}$ & 0.0001 & $+/-$ & 0.0012 & 0.0000 & +/- 0.0012 & 0.0000 & $+/-$ & 0.0012 & 0.0000 & $+/-$ & 0.0030 \\
\hline
\end{tabular}


Table G-1. Chemical Mass Emission Rates for US06 Tests (concluded)

\begin{tabular}{|c|c|c|c|c|c|c|c|c|c|c|}
\hline & \multicolumn{2}{|c|}{ M85 Taurus \#1 } & \multicolumn{2}{|c|}{ M85 Taurus \#2 } & \multicolumn{3}{|c|}{ RFG Taurus \#1 } & \multicolumn{3}{|c|}{ RFG Taurus \#2 } \\
\hline Test Type & & S06 & & SO6 & & US06 & & & US06 & \\
\hline US06 PM & 2.9 & $\mathrm{mg} / \mathrm{mi}$ & 3.5 & $\mathrm{mg} / \mathrm{mi}$ & & $2 \mathrm{mg} /$ & & & $7 \mathrm{mg} /$ & \\
\hline Organic Carbon & 0.3944 & $+/-0.1187$ & 0.3650 & $+/-0.1169$ & 0.3250 & $+/-$ & 0.1115 & 0.1781 & $+/-$ & 0.1039 \\
\hline Elemental Carbon & 0.2428 & $+/-0.0313$ & 0.6442 & $+/-0.0631$ & 0.4760 & $+/-$ & 0.0486 & 1.0348 & $+/-$ & 0.0969 \\
\hline Total Carbon & 0.6371 & $+/-0.1289$ & 1.0093 & $+/-0.1519$ & 0.8009 & $+/-$ & 0.1349 & 1.2129 & $+/-$ & 0.1634 \\
\hline $\mathrm{NO}_{3}^{-}$ & -0.0054 & $+/-0.0136$ & -0.0107 & $+/-0.0136$ & -0.0111 & $+/-$ & 0.0138 & -0.0191 & $+/-$ & 0.0134 \\
\hline $\mathrm{SO}_{4}{ }^{2-}$ & 0.0029 & $+/-0.0130$ & 0.0802 & $+/-0.0157$ & 0.0158 & $+/-$ & 0.0134 & -0.0089 & $+/-$ & 0.0126 \\
\hline $\mathrm{Cl}^{-}$ & 0.1482 & $+/-0.0232$ & 0.0223 & $+/-0.0133$ & -0.0068 & $+/-$ & 0.0129 & -0.0105 & $+/-$ & 0.0124 \\
\hline $\mathrm{NH}_{4}^{+}$ & 0.0847 & $+/-0.0206$ & 0.0781 & $+/-\quad 0.0197$ & 0.0158 & $+/-$ & 0.0135 & 0.0016 & $+/-$ & 0.0124 \\
\hline $\mathrm{Na}$ & -0.0063 & $+/-0.0286$ & -0.0025 & $+/-0.0283$ & -0.0063 & $+/-$ & 0.0263 & -0.0063 & $+/-$ & 0.0234 \\
\hline $\mathrm{Mg}$ & -0.0048 & $+/-0.0116$ & 0.0080 & $+/-\quad 0.0085$ & 0.0016 & $+/-$ & 0.0113 & 0.0000 & $+/-$ & 0.0082 \\
\hline $\mathrm{Al}$ & -0.0017 & $+/-0.0061$ & -0.0037 & $+/-\quad 0.0064$ & -0.0037 & $+/-$ & 0.0062 & -0.0013 & $+/-$ & 0.0047 \\
\hline $\mathrm{Si}$ & 0.4195 & $+/-0.0376$ & 0.5812 & $+/-\quad 0.0521$ & 0.4925 & $+/-$ & 0.0442 & 0.2368 & $+/-$ & 0.0213 \\
\hline $\mathrm{P}$ & 0.0089 & $+/-0.0015$ & 0.0121 & $+/-\quad 0.0017$ & 0.0026 & $+/-$ & 0.0011 & 0.0064 & $+/-$ & 0.0012 \\
\hline S & 0.0095 & $+/-0.0013$ & 0.0680 & $+/-\quad 0.0062$ & 0.0122 & $+/-$ & 0.0014 & 0.0089 & $+/-$ & 0.0012 \\
\hline $\mathrm{Cl}$ & 0.2114 & $+/-0.0192$ & 0.0657 & $+/-\quad 0.0066$ & 0.0046 & $+/-$ & 0.0027 & 0.0052 & $+/-$ & 0.0027 \\
\hline $\mathrm{K}$ & 0.0007 & $+/-0.0021$ & -0.0007 & $+/-\quad 0.0023$ & -0.0011 & $+/-$ & 0.0025 & -0.0007 & $+/-$ & 0.0022 \\
\hline $\mathrm{Ca}$ & 0.0239 & $+/-\quad 0.0027$ & 0.0339 & $+/-\quad 0.0035$ & 0.0148 & $+/-$ & 0.0021 & 0.0248 & $+/-$ & 0.0028 \\
\hline $\mathrm{Ti}$ & 0.0000 & $+/-0.0126$ & 0.0000 & $+/-\quad 0.0122$ & 0.0000 & $+/-$ & 0.0125 & 0.0012 & $+/-$ & 0.0120 \\
\hline V & 0.0000 & $+/-0.0061$ & 0.0000 & $+/-\quad 0.0059$ & 0.0000 & $+/-$ & 0.0061 & 0.0000 & $+/-$ & 0.0058 \\
\hline $\mathrm{Cr}$ & 0.0000 & $+/-\quad 0.0018$ & 0.0002 & $+/-\quad 0.0017$ & 0.0000 & $+/-$ & 0.0018 & 0.0002 & $+/-$ & 0.0017 \\
\hline $\mathrm{Mn}$ & 0.0000 & $+/-\quad 0.0010$ & -0.0001 & $+/-\quad 0.0010$ & -0.0001 & $+/-$ & 0.0010 & -0.0001 & $+/-$ & 0.0010 \\
\hline $\mathrm{Fe}$ & 0.0463 & $+/-0.0042$ & 0.0116 & $+/-\quad 0.0011$ & 0.0313 & $+/-$ & 0.0029 & 0.0055 & $+/-$ & 0.0007 \\
\hline Co & 0.0001 & $+/-\quad 0.0010$ & 0.0001 & $+/-0.0006$ & 0.0000 & $+/-$ & 0.0008 & 0.0000 & $+/-$ & 0.0006 \\
\hline $\mathrm{Ni}$ & 0.0001 & $+/-0.0006$ & 0.0004 & $+/-0.0006$ & 0.0000 & $+/-$ & 0.0006 & 0.0001 & $+/-$ & 0.0006 \\
\hline $\mathrm{Cu}$ & 0.0003 & $+/-0.0006$ & 0.0039 & $+/-\quad 0.0007$ & 0.0003 & $+/-$ & 0.0006 & 0.0018 & $+/-$ & 0.0006 \\
\hline $\mathrm{Zn}$ & 0.0125 & $+/-0.0012$ & 0.0170 & $+/-0.0016$ & 0.0040 & $+/-$ & 0.0006 & 0.0089 & $+/-$ & 0.0009 \\
\hline $\mathrm{Ga}$ & -0.0002 & $+/-0.0010$ & -0.0001 & $+/-\quad 0.0010$ & -0.0002 & $+/-$ & 0.0010 & -0.0002 & $+/-$ & 0.0010 \\
\hline As & 0.0000 & $+/-0.0011$ & 0.0000 & $+/-0.0011$ & 0.0000 & $+/-$ & 0.0011 & 0.0000 & $+/-$ & 0.0011 \\
\hline $\mathrm{Se}$ & 0.0000 & $+/-0.0006$ & 0.0000 & $+/-0.0006$ & 0.0000 & $+/-$ & 0.0006 & 0.0000 & $+/-$ & 0.0006 \\
\hline $\mathrm{Br}$ & 0.0016 & $+/-0.0006$ & 0.0010 & $+/-0.0005$ & 0.0003 & $+/-$ & 0.0005 & 0.0001 & $+/-$ & 0.0005 \\
\hline $\mathrm{Rb}$ & -0.0001 & $+/-0.0005$ & -0.0001 & $+/-0.0005$ & 0.0000 & $+/-$ & 0.0005 & -0.0001 & $+/-$ & 0.0005 \\
\hline $\mathrm{Sr}$ & 0.0003 & $+/-0.0005$ & 0.0001 & $+/-0.0005$ & 0.0003 & $+/-$ & 0.0005 & 0.0001 & $+/-$ & 0.0005 \\
\hline $\mathrm{Y}$ & -0.0001 & $+/-0.0007$ & -0.0001 & $+/-\quad 0.0007$ & 0.0000 & $+/-$ & 0.0007 & -0.0001 & $+/-$ & 0.0007 \\
\hline $\mathrm{Zr}$ & 0.0000 & $+/-0.0008$ & 0.0005 & $+/-\quad 0.0007$ & 0.0000 & $+/-$ & 0.0008 & 0.0003 & $+/-$ & 0.0007 \\
\hline Mo & 0.0000 & $+/-0.0015$ & 0.0001 & $+/-\quad 0.0014$ & 0.0000 & $+/-$ & 0.0014 & 0.0001 & $+/-$ & 0.0014 \\
\hline $\mathrm{Pd}$ & 0.0000 & $+/-0.0041$ & 0.0001 & $+/-0.0041$ & 0.0000 & $+/-$ & 0.0041 & 0.0000 & $+/-$ & 0.0040 \\
\hline $\mathrm{Ag}$ & -0.0007 & $+/-0.0048$ & -0.0008 & $+/-\quad 0.0047$ & -0.0011 & $+/-$ & 0.0048 & -0.0011 & $+/-$ & 0.0047 \\
\hline $\mathrm{Cd}$ & -0.0007 & $+/-0.0049$ & 0.0002 & $+/-\quad 0.0048$ & 0.0001 & $+/-$ & 0.0049 & -0.0007 & $+/-$ & 0.0048 \\
\hline In & -0.0007 & $+/-0.0060$ & -0.0007 & $+/-0.0059$ & 0.0003 & $+/-$ & 0.0060 & -0.0007 & $+/-$ & 0.0058 \\
\hline $\mathrm{Sn}$ & 0.0029 & $+/-0.0073$ & 0.0011 & $+/-\quad 0.0076$ & 0.0010 & $+/-$ & 0.0077 & 0.0000 & $+/-$ & 0.0075 \\
\hline $\mathrm{Sb}$ & 0.0010 & $+/-0.0089$ & 0.0016 & $+/-\quad 0.0088$ & 0.0000 & $+/-$ & 0.0089 & 0.0008 & $+/-$ & 0.0087 \\
\hline $\mathrm{Ba}$ & 0.0056 & $+/-0.0309$ & -0.0073 & $+/-\quad 0.0322$ & 0.0013 & $+/-$ & 0.0309 & -0.0132 & $+/-$ & 0.0319 \\
\hline $\mathrm{La}$ & -0.0034 & $+/-0.0435$ & -0.0023 & $+/-\quad 0.0427$ & 0.0004 & $+/-$ & 0.0435 & -0.0080 & $+/-$ & 0.0424 \\
\hline $\mathrm{Au}$ & -0.0002 & $+/-0.0017$ & -0.0002 & $+/-\quad 0.0017$ & -0.0002 & $+/-$ & 0.0016 & -0.0002 & $+/-$ & 0.0016 \\
\hline $\mathrm{Hg}$ & -0.0002 & $+/-0.0013$ & -0.0001 & $+/-0.0013$ & -0.0001 & $+/-$ & 0.0013 & -0.0002 & $+/-$ & 0.0013 \\
\hline $\mathrm{Tl}$ & -0.0002 & $+/-\quad 0.0012$ & -0.0002 & $+/-\quad 0.0012$ & -0.0002 & $+/-$ & 0.0012 & -0.0002 & $+/-$ & 0.0012 \\
\hline $\mathrm{Pb}$ & 0.0004 & $+/-0.0016$ & 0.0012 & $+/-\quad 0.0015$ & 0.0003 & $+/-$ & 0.0016 & 0.0001 & $+/-$ & 0.0016 \\
\hline $\mathrm{U}$ & 0.0000 & $+/-0.0012$ & 0.0000 & $+/-0.0012$ & 0.0000 & $+/-$ & 0.0012 & 0.0000 & $+/-$ & 0.0012 \\
\hline
\end{tabular}




\section{REPORT DOCUMENTATION PAGE}

Form Approved

OMB NO. 0704-0188

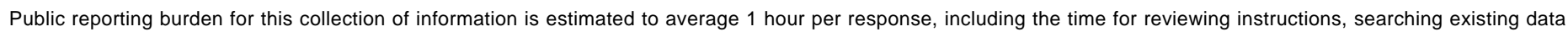

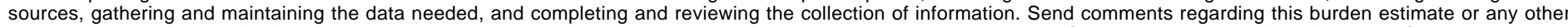

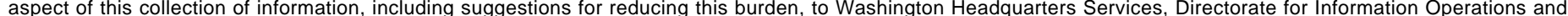

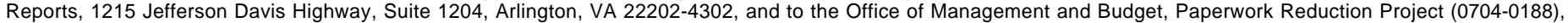
Washington, DC 20503.

1. AGENCY USE ONLY (Leave blank)

\begin{tabular}{l|l} 
2. REPORT DATE \\
November 1998
\end{tabular}

\section{TITLE AND SUBTITLE}

Particulate Measurements and Emissions Characterization of Alternative Fuel Vehicle Exhaust

\section{AUTHOR(S)}

Thomas D. Durbin, Timothy J. Truex, and Joseph M. Norbeck

\section{PERFORMING ORGANIZATION NAME(S) AND ADDRESS(ES)}

University of California at Riverside

Center for Environmental Research and Technology

College of Engineering

Riverside, CA 92521

\section{SPONSORING/MONITORING AGENCY NAME(S) AND ADDRESS(ES)}

National Renewable Energy Laboratory

1617 Cole Blvd.

Golden, CO 80401

\section{SUPPLEMENTARY NOTES}

\section{2a. DISTRIBUTION/AVAILABILITY STATEMENT}

12b. DISTRIBUTION CODE

National Technical Information Service

U.S. Department of Commerce

5285 Port Royal Road

Springfield, VA 22161

13. ABSTRACT (Maximum 200 words) The objective of this project was to measure and characterize particulate emissions from light-duty alternative fuel vehicles (AFVs) and equivalent gasoline-fueled vehicles. The project included emission testing of a fleet of 129 gasoline-fueled vehicles and 19 diesel vehicles. Particulate measurements were obtained over Federal Test Procedure and US06 cycles. Chemical characterization of the exhaust particulate was also performed. Overall, the particulate emissions from modern technology compressed natural gas and methanol vehicles were low, but were still comparable to those of similar technology gasoline vehicles.

\section{SUBJECT TERMS}

Alternative transportation fuels, particulate emissions, compressed natural gas, methanol

15. NUMBER OF PAGES 75

16. PRICE CODE

17. SECURITY CLASSIFICATION OF REPORT

\author{
18. SECURITY CLASSIFICATION \\ OF THIS PAGE
}

19. SECURITY CLASSIFICATION OF ABSTRACT
20. LIMITATION OF ABSTRACT 